Cláudio Romero Farias Marinho

\title{
CORRELAÇÃO ENTRE A CARGA PARASITÁRIA NA FASE AGUDA E A INTENSIDADE DA PATOLOGIA, PARASITISMO E ATIVAÇÃO DO SISTEMA IMUNE NA FASE CRÔNICA DA DOENÇA DE CHAGAS EXPERIMENTAL
}

Dissertação apresentada ao Instituto de Ciências Biomédicas da Universidade de São Paulo, para obtenção do título de Mestre em Imunologia

São Paulo 1998 
Cláudio Romero Farias Marinho

\title{
CORRELAÇÃO ENTRE A CARGA PARASITÁRIA NA FASE AGUDA E A INTENSIDADE DA PATOLOGIA, PARASITISMO E ATIVAÇÃO DO SISTEMA IMUNE NA FASE CRÔNICA DA DOENÇA DE CHAGAS EXPERIMENTAL
}

\author{
Dissertação apresentada ao Instituto \\ de Ciências Biomédicas da \\ Universidade de São Paulo, para
} Orientador: Prof. Dr. José Maria Alvarez Mosig

São Paulo 1998 
Candidato(a): CLÁUDIO ROMERO FARIAS MARINHO

Título da Dissertação:

Correlação entre a carga parasitária na fase aguda e a intensidade da patologia,

\section{A Comissão Julgadora dos trabalhos de}

Defesa da Dissertação de Mestrado, em sessão

pública realizada a ................................., considerou

$$
\text { o(a) candidato(a): }
$$

( ) Aprovado(a)

) Reprovado(a)

1) Examinador(a) 
DADOS DE CATALOGAÇÃO NA PUBLICAÇÃO (CIP)

Serviço de Biblioteca e Informação Biomédica do

Instituto de Ciências Biomédicas da Universidade de São Paulo

Marinho, Claudio Romero Farias.

Correlação entre a carga parasitária na fase aguda e a intensidade da patologia, parasitismo e ativação do sistema imune na fase crônica da doença de Chagas experimental/ Claudio Romero Farias Marinho. -- São Paulo, 1998.

Tese (Doutorado) -- Instituto de Ciências Biomédicas da Universidade de São Paulo. Departamento de Imunologia. Área de concentração: Imunologia.

Linha de pesquisa: Imunologia da doença de Chagas.

Orientador: Alvarez-Mosig, Jose Maria.

Versão do título para o inglês: Influence of acute phase parasite load on pathology, parasitism and activation of the immune system at the late chronic phase of Chagas'disease.

Descritores: 1. Doença de Chagas $\quad$ 2. Trypanosoma cruzi $\quad$ 3. Patologia $\quad$ 4. Cepa Y 5. Fase Crônica 6. Linhagens isogênicas A/J 
Trabalho desenvolvido no laboratório de "Imunologia das Parasitoses” do Departamento de Imunologia do ICB/USP, com auxílio financeiro do CNPq (Proc. №: 830656/98-7) 


\section{A minha mãe,}

pelo apoio e incentivo. 


\section{Agradecimentos}

Ao professor e amigo José Maria A. Mosig, pela orientação e incentivo durante todos estes anos de trabalho.

A Maria Regina D’Império Lima, pelas valiosas sugestões apresentadas no desenvolvimento deste trabalho.

As professoras Anna Maria Simonsen Stolf, Fabíola Cardillo e Zuleica Caulada Benedetti, pelas sugestões apresentadas no exame de qualificação.

À amiga Fátima Dias, pelo incentivo e cuidadoso trabalho de revisão deste manuscrito.

Aos amigos do laboratório Regiane, Karina, Gláucia, Andressa e Luiz pela ajuda em diversos momentos na realização deste trabalho.

A minha querida Adriana de Oliveira Pires, pela ajuda, amizade e paciência.

Ao meu grande amigo Pira, pela ajuda e pelas conversas, sempre proveitosas, no "Rei das Batidas”.

A Kadu, pelas inúmeras discussões, ajuda e amizade.

A Ulisses, pela ajuda, principalmente na solução de problemas nos computadores.

A Irene Symphônio e Paulo Albe pela colaboração e apoio técnico.

A Valéria, Eni e Andréia pela ajuda nos assuntos burocráticos.

Aos queridos amigos do Departamento de imunologia Rosa, Ana Lúcia, Adriana, Eliana, Vlaudia, Jacqueline, Ana Paula, Val, Marcello e Ademir.

E a todos aqueles que foram importantes nesta fase e que, de alguma forma, contribuíram para realização deste trabalho. 


\section{ABREVIATURAS}


ADCC- "Antibody-dependent cell cytotoxicity"(Citotoxicidade celular dependente de anticorpos)

AMP- "2-Amino 2-methyl 1-propanol"

BCIP. "5-Bromo chloro 3-indolyl phosphate"

BSA- "Albumin bovine" (Albumina bovina)

C3,C4,C5 - Componentes 3,4 e 5 do sistema complemento

CCR3- "Human eotaxin-receptor CCR3"

CD- "Cluster of differentiation" (antígeno de membrana celular)

ConA- "Concanavalin A" (Concanavalina A)

CPH- Complexo Principal de Histocompatibilidade

DMEM- “Dulbecco's modified Eagle's Medium”

D.O.- Densidade Ótica

ELISA- "Enzyme-linked immunosorbent assay" (Ensaio imunoenzimático)

FACS- "Fluorescence-activated cell sorter" (Ensaio de citometria de fluxo)

Fc- "Fragment cristalizable" (Fragmento cristalizável)

FCS- "Fetal calf serum" (Soro fetal bovino)

FITC-“Fluorescein Isothiocyanate" (Isotiocianato de Fluoresceína)

GM-CSF- "Granulocyte-macrophage colony-stymulating factor"

h- hora

$\mathrm{H}_{2} \mathrm{O}_{2}-$ Água Oxigenada

i.g.- intragástrico

i.p.- intraperitoneal

IFN- Interferon

Ig- Imunoglobulina

IL- Interleucinas

LAK- "Limphokine Activated Killer"

ME- Mercaptoetanol

Min.- Minutos

NK- "Natural Killer"

NO- "Nitric oxide" (Óxido nítrico)

OMS- Organização Mundial da Saúde

OPD- "o-Phenilenediamine" (o-Fenilenodiamina)

PBS- "Phosphate buffered saline" (Salina tamponada com fosfato) 
PCR- "Polymerase Chain Reaction"

PE- Peroxidase

PFC- "Plaque Forming Cells" (Células Formadoras de Placas)

PGs- Prostaglandinas

PMN- Polimorfonucleares

scid- "Severe combined immune deficiency"

SFM- Sistema Fagocítico Mononuclear

Th- "Limphocyte T helper" (Linfócito T auxiliador)

TGF $\beta$ - "Transforming Growth Factor $\beta$ "

TNF $\alpha$ - "Tumor Necrosis Factor $\alpha$ " (Fator de Necrose Tumoral $\alpha$ ) 
Este projeto teve como objetivo definir se a carga parasitária na fase aguda afeta a parasitemia, a patologia e a resposta imune na fase crônica da doença de Chagas experimental. Com o objetivo de obtermos diferentes cargas parasitárias na fase aguda, camundongos $\mathrm{A} / \mathrm{J}$ foram infectados com $10^{3}$ ou $10^{5}$ formas tripomastigotas de T. cruzi (cepa Y) e posteriormente tratados com Benzonidazol no dia 6 de infecção. Um ano depois, os animais crônicos foram avaliados quanto a parasitemia sub-patente, intensidade de patologia e ativação do sistema imune. Nossos resultados mostram que os animais infectados com alto inóculo ( $10^{5}$ formas) possuíam um ano depois, um maior nível de parasitemia residual, uma maior intensidade de inflamação no coração e no músculo esquelético e um maior grau de ativação do sistema imune quando comparados aos animais infectados com baixo inóculo (10 $0^{3}$ formas). Em relação aos parâmetros imunológicos analisados, observou-se nos animais infectados com maior inóculo: i) um número superior de esplenócitos, com expansão preferencial das populações B220CD5- (possivelmente macrófagos) e linfócitos $\mathrm{CD}^{+}$; ii) uma freqüência maior de blastos nas populações

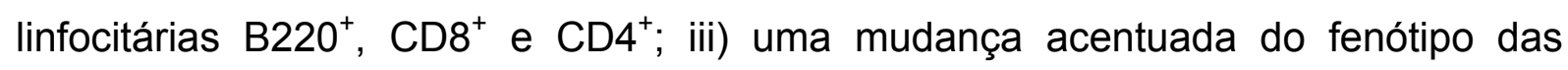
células $\mathrm{CD}^{+}$para $\mathrm{CD} 4^{+} \mathrm{CD} 45 \mathrm{RB}^{\mathrm{Low}}$, indicando um aumento das células efetoras e/ou de memória; iv) freqüências mais elevadas de blastos $C D 4^{+} C D 45 R^{\text {High }}$ e CD4 ${ }^{+}$CD45RB ${ }^{\text {Low; }}$ v) um número superior de células secretoras de imunoglobulinas com predomínio de células secretoras de IgG2a; vi) uma produção maior de IFN- $\gamma$ e de IL-4; vii) níveis séricos de anticorpos específicos para o parasita inferiores para IgM e superiores para IgG2a e IgG1. Nossos resultados indicam, portanto, que a carga parasitária na fase aguda da infecção pelo Trypanosoma cruzi influencia a ativação do sistema imune e o desenvolvimento de patologia na fase crônica da doença de Chagas. 
The objective of this project is to evaluate if the parasite load in the acute phase experimental Chagas' disease affects the parasitemias, the pathology and the immune response in the chronic phase. To obtain low- and high-parasite loads in the acute phase of the disease, A/J mice were infected with 103 or $105 \mathrm{~T}$. cruzi trypomastigotes of the $Y$ strain, and treated on day 6 with Benzonidazol. One year later, chronic mice were screened for subpatent parasitemias, tissue pathology and immune response. Mice infected with the high parasite inoculum showed higher levels of chronic parasitemias, heart and striated muscle inflammation and activation of the immune system when compared to mice infected with the low-dose inoculum. Concerning the activation of the immune system, the main findings in high-dose infected mice were: i) increased numbers of splenocytes, with preferential expansion of CD8+ and B220-CD5- cells, many of them bearing a macrophage phenotype; ii) higher frequencies of $\mathrm{B}(\mathrm{B} 220+), \mathrm{CD} 4+$ and $\mathrm{CD} 8+$ large lymphocytes; iii) a shift of CD4+ cells towards a CD45RBLow phenotype; iv) increased frequencies of both CD45RBLow and CD45RBHigh large CD4+ cells; v) augmented numbers of total Igsecreting cells, with predominance of IgG2a-producing cells, and; vi) increased production of IFN- $g$ and IL-4. In addition, these mice presented lower IgM and higher $\lg$ G2a and IgG1 parasite-specific serum antibody levels. Our results indicate that the parasite load at the acute phase of $\mathrm{T}$. cruzi infection influences the activation of the immune system and development of Chagas pathology at the late chronic phase of the disease. 
1. INTRODUÇÃO .

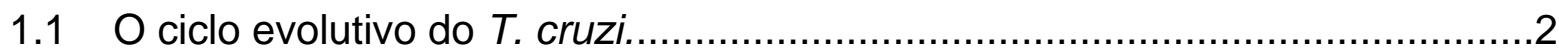

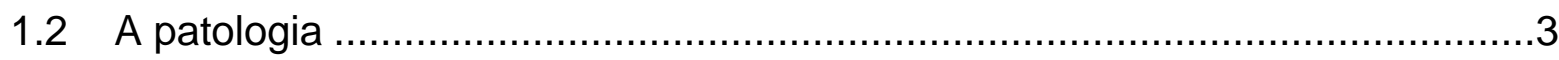

1.3 O sistema imune na infecção pelo $T$. cruzi ...........................................4

1.3.1 Mecanismos naturais de resistência ................................................. 4

1.3.2 A resposta imune humoral..............................................................

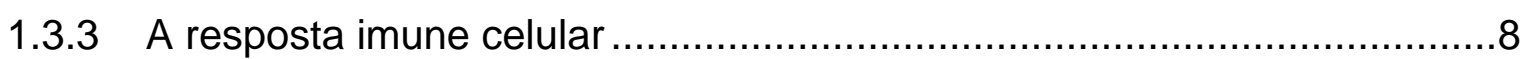

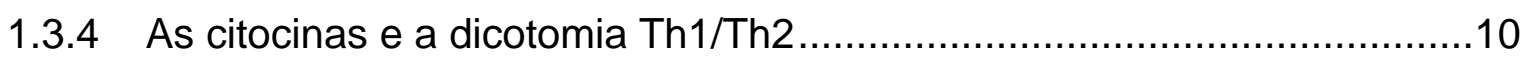

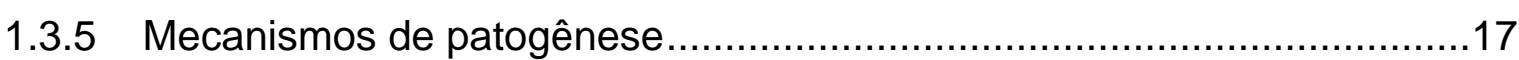

2. OBJETIVOS Erro! Marcador não definido.

3. MATERIAIS E MÉTODOS Erro! Marcador não definido.

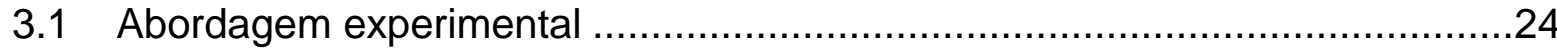

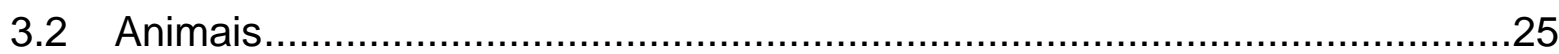

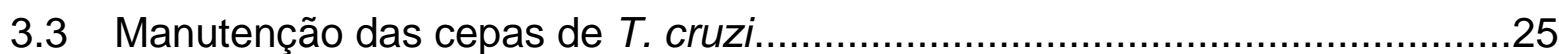

3.4 Modelos de infecção e tratamento quimioterápico específico ......................25

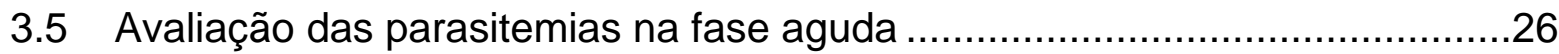

3.6 Avaliação das parasitemias na fase crônica.........................................26

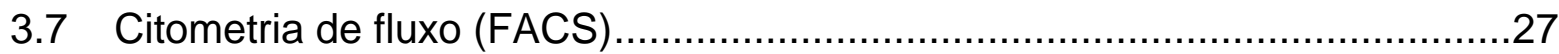

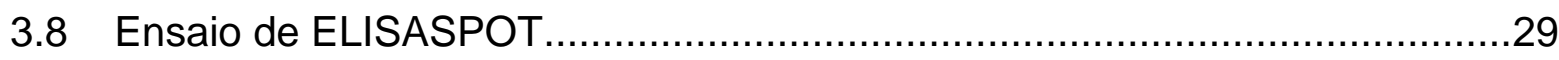

3.9 Obtenção dos sobrenadantes de cultura de células esplênicas ....................30

3.10 Dosagem de citocinas nos sobrenadantes de cultura celular........................31

3.11 Obtenção de formas tripomastigotas de cultura e preparo de antígeno

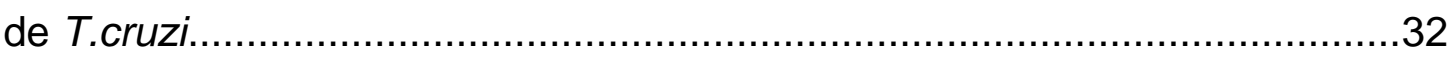

3.12 Dosagem de anticorpos específicos anti-T. cruzi .....................................32

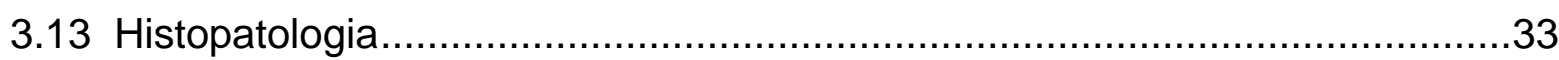

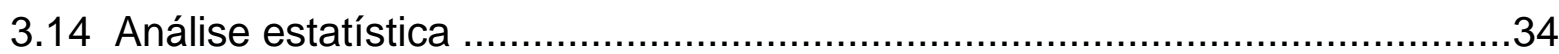

4. RESULTADOS......................................................... Erro! Marcador não definido.

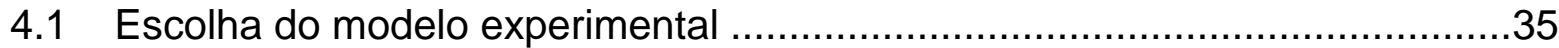

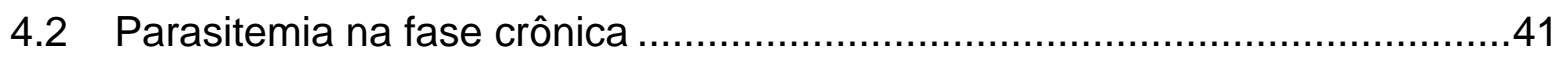

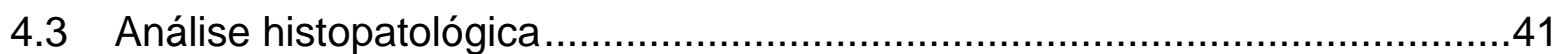

4.4 Análise da celularidade esplênica ....................................................31

4.5 Análise das populações linfocitárias esplênicas ....................................31

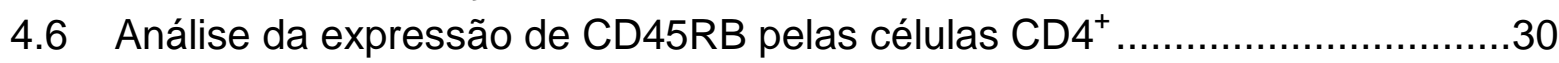

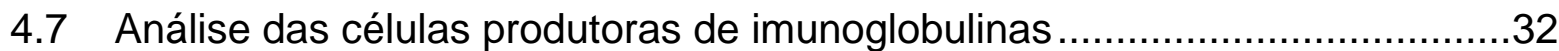

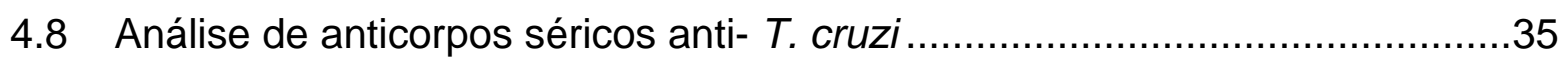

4.9 Análise de citocinas secretadas por células esplênicas ..............................35

5. DISCUSSÃO Erro! Marcador não definido.

6. CONCLUSÕES Erro! Marcador não definido.

7. REFERÊNCIAS BIBLIOGRÁFICAS.......................... Erro! Marcador não definido. 
A doença de Chagas, primeiramente descrita por Carlos Chagas em 1909 (CHAGAS, 1909), é endêmica nas Américas. A Organização Mundial de Saúde (OMS) estima que cerca de 18 milhões de pessoas estejam infectadas pelo Trypanosoma cruzi, o agente etiológico desta doença, em dezoito países latino-americanos, com cerca de 90 milhões ainda expostas ao risco de infecção (WHO, 1991).

No Brasil, a doença afeta principalmente zonas rurais, no entanto ela tem se tornado cada vez mais um fenômeno urbano, devido às migrações de populações por fatores sócio-econômicos, transmissões congênitas ou transfusionais. Esta doença continua ainda tendo um grande impacto social, que se reflete em elevados custos médico-hospitalares e taxas de aposentadoria precoce que ocorrem como conseqüência direta da infecção pelo parasita (TEIXEIRA, 1987).

\subsection{O ciclo evolutivo do T. cruzi.}

O T. cruzi é um protozoário flagelado da família trypanosomatidae que tem um ciclo de vida digenético, envolvendo estágios morfo e fisiologicamente distintos, tanto no hospedeiro vertebrado, como nos insetos hematófagos, membros da sub-família Triatominae. O inseto vetor, ao se alimentar do sangue do hospedeiro vertebrado, defeca nas proximidades da picada podendo transmitir através da pele lesada ou das mucosas íntegras as formas tripomastigotas metacíclicas infectantes. Estas formas parasitam diferentes tipos de células, principalmente fagócitos mononucleares, fibras musculares e fibroblastos. Ao penetrar no citoplasma destas células o parasita transforma-se na forma amastigota que se reproduz por divisão binária, as quais transformando-se posteriormente em tripomastigotas que são liberadas alcançando a circulação e disseminando a infecção. Os tripomastigotas sanguícolas podem ser ingeridos pelo inseto vetor onde, no lúmen do trato digestivo, transformam-se nas formas epimastigotas. Estas formas multiplicamse no tubo digestivo do inseto, diferenciando-se na sua porção terminal em tripomastigotas metacíclicos que podem ser transmitidos ao hospedeiro 
vertebrado fechando assim, seu ciclo de vida (BRENER \& ANDRADE, 1987; REY, 1991; RUPPERT \& BARNES, 1994).

\subsection{A patologia}

Com base nas características clínicas, três fases da infecção têm sido descritas: aguda, indeterminada e crônica. A fase aguda pode durar de 3 ou 4 meses, muitas vezes totalmente assintomática para adultos a despeito da presença de parasitas circulantes no sangue. Sinais clínicos como reação inflamatória local na porta de entrada do parasita (chagoma de inoculação, sinal de Romaña), febre, esplenomegalia e miocardite são encontrados com maior freqüência em crianças e raramente em adultos. As alterações histopatológicas observadas no miocárdio durante esta fase, incluem a presença de infiltrado inflamatório, miocardite degenerativa, formação de cistos, além de destruição neuronal que tem sido relacionada a danos teciduais provocados tanto pelo parasita, quanto pela resposta imune. Essas alterações podem ser determinantes na severidade dos sintomas apresentados mais tarde durante a fase crônica (ANSELMI \& MOLEIRO, 1974). Estima-se que 5 a 10\% dos casos agudos não tratados são fatais, sobretudo em crianças.

A medida que a resposta imune progride e a parasitemia é controlada, as funções cardíacas retornam ao normal e os infiltrados inflamatórios tendem a regredir. Assim, a doença evolui para a fase indeterminada, onde o indivíduo não apresenta nenhum tipo de manifestação clínica e na qual os parasitas só podem ser detectados através de xenodiagnóstico, hemocultura, e mais recentemente, pela amplificação enzimática do DNA do parasito (CAMARGO \& TAKEDA, 1979; BRENER, 1980; FRASH \& REYES, 1990).

A fase indeterminada pode persistir por toda a vida do indivíduo. Entretanto, cerca de $30 \%$ dos pacientes infectados vêm a desenvolver a síndrome característica da fase crônica, caracterizada pelo aparecimento das manifestações cardíacas e/ou digestivas. A sintomatologia crônica pode incluir redução da função cardíaca com dilatação das câmaras e alterações eletrocardiográficas (ANDRADE \& ANDRADE, 1979). As anormalidades 
digestivas manifestam-se pela hipertrofia e dilatação dos órgãos do trato digestivo, principalmente do cólon e do esôfago, como conseqüência da desnervação de células ganglionares do plexo mesentérico (KOBERLE, 1974).

Até o presente momento, não se conhecem relatos de cura espontânea na doença de Chagas, isto é, não há evidências de que se desenvolva uma imunidade esterilizante que leve à total eliminação do parasita. Quanto à quimioterapia específica, existem apenas duas drogas que são parcialmente eficazes contra o parasita: o Nifurtimox e o Benzonidazol (HABERKORN \& GONNERT, 1972). A eficácia do tratamento é maior quando estas drogas são administradas logo após a infecção; no entanto, elas parecem ser menos ativas em estágios avançados da doença, além de serem bastante tóxicas e totalmente ineficazes contra determinadas cepas do parasita (CANÇADO, 1985).

\subsection{O sistema imune na infecção pelo $T$. cruzi}

\subsubsection{Mecanismos naturais de resistência}

Os mecanismos de resistência natural do hospedeiro não são totalmente eficazes no controle da infecção, necessitando da cooperação do sistema linfocitário para a destruição dos parasitas.

Os diferentes estágios evolutivos do $T$. cruzi têm variada capacidade de ativar o sistema complemento, diferindo na susceptibilidade à lise pelo mesmo. As formas epimastigotas encontradas no inseto vetor ou provenientes de cultura são altamente sensíveis à lise pelo complemento (MUNIZ \& BORRIELO, 1945), enquanto as formas tripomastigotas e amastigotas são resistentes (BUDZKO et al., 1975; KIERSZENBAUM \& HOWARD, 1976; KIERSZEMBAUN \& LIMA, 1983; KIPNIS et al., 1985). A participação do complemento na lise de tripomastigotas mediada por anticorpos foi evidenciada em ensaios in vitro (KRETTLI et al.,1979). Este fenômeno, no entanto, parece não ter um papel fundamental in vivo, uma vez que a parasitemia e a patologia, 
assim como o "clearance" do T. cruzi do sangue, não são alteradas em animais deficientes de C5 ou C4 (KRETTLI, 1978; DALMASSO \& JARVINEN, 1980; UMEKITA, 1991). O sistema complemento parece ter, entretanto, uma função importante no controle da infecção pelo $T$. cruzi, provavelmente devido à sua capacidade opsonizadora, uma vez que, animais depletados de C3 pelo tratamento com o CVF (fator de veneno de cobra) têm uma agravamento da infecção (BUDZKO, et al., 1975).

As células do Sistema Fagocítico Mononuclear (monócitos e macrófagos) são fundamentais no controle do parasita no sangue e nos tecidos. Entretanto, elas podem desempenhar um papel duplo na infecção pelo T. cruzi, ora servindo como células efetoras da resposta imune frente ao parasita, ora como células hospedeiras responsáveis pela multiplicação e diferenciação do mesmo (COHN, 1978; NOGUEIRA et al., 1982). Entretanto, é inegável o fato de que a fagocitose por estas células tem uma certa capacidade de limitar a replicação do parasita. A administração de partículas de sílica (composto seletivamente tóxico para macrófagos) no início da infecção, para camundongos infectados com T. cruzi, aumenta acentuadamente a parasitemia e a mortalidade dos animais (KIERSZEMBAUM et al., 1974 ). Apesar deste fato, a fagocitose não parece ser um mecanismo suficientemente eficiente para a destruição dos parasitas, uma vez que, quando fagocitados, muitos conseguem passar para o citoplasma, onde diferenciam-se em amastigotas possibilitando a sua perpetuação (ALCÂNTARA \& BRENER, 1978). Por outro lado, como veremos mais adiante, após a ativação linfocitária, os macrófagos tornam-se elementos fundamentais no controle do parasita mediando a destruição intracelular destes.

As células NK (do inglês, Natural Killer) parecem ter um papel importante na infecção pelo $T$. cruzi. Um aumento precoce e significante da atividade das células NK tem sido reportado em animais infectados com $T$. cruzi. HATCHER \& KUHN (1982) foram os primeiros a demonstrar em ensaios in vitro a efetiva participação das células NK na destruição de epimastigotas e tripomastigotas. Recentemente, CARDILLO et al. (1996) sugeriram que nos 
estágios iniciais da infecção, as células NK, através da produção de interferon- $\gamma$ (IFN- $\gamma$ ), promoveriam a ativação de macrófagos para a destruição intracelular do parasita. Neste sentido, esses mesmos autores observaram que as células NK seriam as principais produtoras de IFN- $\gamma$ nesta fase da infecção, processo este provavelmente dependente da produção de interleucina 12 (IL-12) pelos macrófagos (ALIBERTI et al.,1996). Este aumento na atividade de células NK no início da infecção pode contribuir para a limitação da replicação do parasita até o estabelecimento da resposta imune específica. As células NK representam uma importante ponte entre a imunidade inata, que opera com limitada especificidade e eficiência, e a imunidade específica, caracterizada pela seleção clonal e a expansão de linfócitos específicos para o antígeno (KOS \& ENGLEMAN, 1996).

\subsubsection{A resposta imune humoral}

Os anticorpos específicos têm um papel fundamental na defesa do hospedeiro vertebrado contra o T. cruzi, pelo seu papel efetor frente às formas tripomastigotas circulantes e tissulares. Eles são em grande parte responsáveis pelo controle da parasitemia no fim da fase aguda e pela manutenção de baixos níveis de parasitas circulantes durante as fases indeterminada e crônica.

Destaca-se a participação dos anticorpos em diversos processos efetores contra o parasita. Entre eles, podemos citar:

i) remoção, do sangue, dos tripomastigotas, recobertos por anticorpos e complemento, por macrófagos e outras células do Sistema Fagocítico Mononuclear (SFM), processo que pode resultar na destruição intracelular dos parasitas (ALCÂNTARA \& BRENER, 1978 ).

ii) opsonização e destruição dos parasitas nos tecidos, mediada por polimorfonucleares (PMN) ou macrófagos (ALCÂNTARA \& BRENER, 1978, ABRAHAMSOHN, 1988).

iii) destruição dos parasitas nos tecidos, por citotoxicidade dependente de anticorpos (ADCC) mediada por diversos elementos celulares tais como células NK, eosinófilos, neutrófilos e mastócitos (ABRAHAMSOHN \& DIAS DA 
SILVA, 1977; KIERSZENBAUM \& HAYES, 1980a; KIPNIS et al.,1981; TAMBOURGI et al.,1989).

iv) foi também sugerida a participação dos anticorpos no controle do $T$. cruzi através de destruição por plaquetas de parasitas sanguícolas opsonizados por anticorpos e complemento (UMEKITA \& MOTA, 1989).

iv) entretanto, como citado acima, o papel dos anticorpos na lise de tripomastigotas mediada por complemento, mecanismo sugerido anos atrás com base em experiências in vitro, não é considerado hoje como um mecanismo importante no controle do $T$. cruzi.

Reforçando a importância da resposta imune humoral frente à infecção, KIERSZENBAUM \& HOWARD (1976), utilizando camundongos Biozzi maus e bons produtores de anticorpos, observaram uma correlação inversa entre a capacidade de produção de anticorpos e a suscetibilidade à infecção por $T$. cruzi. Posteriormente, foi mostrado que injeções neonatais de anticorpos anticadeia $\mu$, que resultam na eliminação das células $B$, promovem um aumento de susceptibilidade na fase aguda (RODRIGUEZ et al.,1981).

Existe, atualmente, o consenso de que os anticorpos protetores são imunoglobulinas (Ig) pertencentes à classe IgG (TAKEHARA et al.,1981; SCOTT \& GROSS-SAMPSON, 1984). Em experimentos de transferência passiva, a atividade protetora está associada, no camundongo, principalmente aos anticorpos das subclasses IgG2a e IgG2b (TAKEHARA et al.,1981). Estes isótipos são considerados mais efetivos contra o parasita, uma vez que, dentre as diferentes subclasses de IgG, são os que têm uma maior capacidade de ativar o sistema complemento após a sua ligação com o antígeno, e são aqueles que interagem com maior afinidade com os receptores para $F c(F c R)$, facilitando, desta maneira, a sua ingestão por macrófagos (KLAUS et al.,1979; STEFANI et al.,1983). Alguns autores descreveram que os anticorpos específicos IgG2a (SPINELLA et al.,1992) e IgG2b (MINOPRIO et al., 1986) são predominantes na fase crônica da infecção chagásica murina. Entretanto, alguns pesquisadores têm detectado apenas IgG2b como isótipo predominante na resposta imune específica, isto deve-se ao fato de que o gene que codifica a IgG2a encontra-se deletado em algumas linhagens de camundongos (MARTIN et al., 1997). 
Durante a infecção aguda murina pelo $T$. cruzi é observada uma ativação policlonal dos linfócitos que se prolonga até a fase crônica (MINOPRIO et al., 1989a). Esta ativação é caracterizada por uma expansão e diferenciação maciça dos linfócitos T e B, com hipergamaglobulinemia (ORTIZORTIZ, 1980; D'IMPÉRIO-LIMA et al.,1985 e 1986; MINOPRIO et al., 1986); sendo os isótipos predominantes a IgG2a ou a IgG2b (SCOTT \& GOSSSAMPSON, 1984; MINOPRIO et al., 1986; SPINELA et al., 1992). A ativação policlonal é caracterizada pelo predomínio de uma resposta não específica frente ao parasita (MINOPRIO et al., 1988; SPINELA et al., 1992), que é acompanhada por imunossupressão das respostas humorais e celulares contra antígenos heterólogos e homólogos (TEIXEIRA et al., 1978; ROWLAND \& KUHN, 1978; CUNNIGHAM \& KUHM, 1980; REED et al., 1983). MINOPRIO et al. (1989b) sugeriram que a ativação policlonal pode desempenhar um papel importante no estabelecimento da patologia da doença de Chagas, uma vez que a expansão linfocitária inclui clones autorreativos, determinando a produção de autoanticorpos. Assim, tanto no homem, quanto no camundongo infectado pelo $T$. cruzi, são detectados no soro autoanticorpos contra componentes próprios tais como estruturas cardíacas e vasculares (GEA et al., 1990; LAGUENS et al., 1991; TIBBETTS et al., 1994), laminina (em humanos) (TOWBIN et al., 1987; GAZINNELLI et al., 1988; MILEl et al., 1993), estruturas nervosas (WOOD, et al., 1982; GEA, et al., 1993), receptores adrenérgicos (STERIN-BORDA, et al., 1988), miosina (CUNHA-NETO et al., 1995), actina, tubulina, mioglobina, DNA (TERNYNCK, et al., 1990) e proteína ribossomal $P$ (SKEIKY et al., 1993).

\subsubsection{A resposta imune celular}

Os linfócitos $\mathrm{T} \mathrm{CD}^{+}$e $\mathrm{CD}^{+}$são fundamentais no estabelecimento da resistência do hospedeiro ao $T$. cruzi. Camundongos deficientes de células $\mathrm{CD}^{+}, \mathrm{CD}^{+}$ou ambas, quando infectados pelo $T$. cruzi, revelam uma suscetibilidade aumentada à infecção. A depleção destas populações celulares induzem nos animais altos níveis de parasitemia e mortalidade (RUSSO et al., 
1988; ARAÚJO, 1989; TARLETON, 1990; TARLETON et al., 1992; ROTTEMBERG et al., 1993; ROTTEMBERG et al., 1995 e RUSSO et al., 1996).

RUSSO et al. (1988) observaram que, em camundongos, a depleção de linfócitos $\mathrm{CD}^{+}$, através do tratamento com anticorpos monoclonais durante a fase aguda, claramente inibia as atividades dependentes de células T CD4 ${ }^{+}$, como ativação de macrófagos peritoneais e de linfócitos B. Nesses animais, o número de parasitas no sangue e nos tecidos aumentou, enquanto que, o número de infiltrados inflamatórios no coração diminuiu. Posteriormente, estes resultados foram confirmados por ROTTEMBERG et al. (1995) utilizando camundongos "knock out" de linfócitos T CD4 ${ }^{+}$.

De forma análoga, TARLETON (1990) demonstrou que animais depletados de células $\mathrm{CD}^{+}$, previamente à infecção, tornavam-se altamente suscetíveis na fase aguda da doença. Entretanto, quando esta depleção ocorria na fase crônica, os grupos experimentais tinham índices de sobrevida semelhantes aos dos controles e não sofriam agravamento da parasitemia, sugerindo que as células $\mathrm{CD}^{+}$são importantes no controle da infecção aguda, mas não na manutenção da imunidade na fase crônica. Posteriormente, o papel das células $\mathrm{CD}^{+}$na fase aguda foi confirmado, pelo mesmo autor, em animais deficientes de $\beta 2-$ microglobulina que não possuem células $C^{2} 8^{+}$ (TARLETON, et al., 1992).

ROTTEMBERG et al.(1995) utilizando animais "knock out" de linfócitos $\mathrm{CD}^{+}, \mathrm{CD}^{+}$, ou de ambas as moléculas, demonstraram que apenas os animais deficientes de células $C D 4^{+}$são incapazes de controlar o parasita no coração. Posteriormente, foi proposto por RUSSO et al. (1996) que o controle exercido por estas populações celulares pode ser diferente, dependendo do órgão parasitado. Desta maneira, células $\mathrm{CD}^{+}$estariam envolvidas no controle da infecção no coração, e células $\mathrm{CD}^{+}$e $\mathrm{CD}^{+}$estariam inibindo a multiplicação do parasita no fígado. Os autores justificaram o não envolvimento das células $\mathrm{CD}^{+}$no controle do parasitismo cardíaco em função de uma eventual baixa expressão de moléculas do complexo principal de histocompatibilidade (CPH) classe I pelos cardiomiócitos (BERAH et al.,1970). Entretanto, recentemente TARLETON \& ZHANG (1996) mostraram que células CD8 ${ }^{+}$estavam presentes 
nas lesões cardíacas na fase crônica. Nestas lesões foi observado um aumento da expressão de moléculas do CPH classe I e II, e a presença de uma série de linfocinas inflamatórias e anti-inflamatórias. Esses autores também observaram que o grupo de citocinas produzidas no local da lesão é diferente daquele encontrado nos órgãos linfóides, não havendo associação entre um grupo particular de linfocinas e o desenvolvimento da patologia.

\subsubsection{As citocinas e a dicotomia Th1/Th2}

No final dos anos 80, foi proposto por MOSMANN et al. (1986) que os linfócitos $\mathrm{T} \mathrm{CD}^{+}$poderiam ser divididos em duas sub-populações com base no conjunto de citocinas que produziam. Assim, em modelos murinos, as células do tipo Th1 produzem interleucina 2 (IL-2), IFN- $\gamma$ e linfotoxina (LT), enquanto que as células do tipo Th2 secretam interleucina 4,5,6,9,10 e 13 (IL-4, IL-5, IL6, IL-9, IL-10 e IL-13). A produção de outras citocinas como IL-3, fator de necrose tumoral $\alpha$ (TNF- $\alpha$ ) e fator estimulante de colônia de macrófago e granulócito (GM-CSF) são compartilhadas por ambas as sub-populações celulares. Células CD4 "naive" recém ativadas produzem unicamente IL-2 e são consideradas as precursoras (Thp) dos outros fenótipos celulares. A partir destas células THp, ocorreria uma diferenciação com expressão dos dois conjuntos de citocinas, fenótipo que têm sido denominado de Th0. A partir deste ponto aconteceria a polarização para Th1 ou Th2, fenótipos que uma vez instaurados, seriam irreversíveis. Recentemente, foi descrito um outro fenótipo de células $C D 4^{+}$que produzem exclusivamente altas quantidades de fator de transformação do crescimento $\beta$ (TGF- $\beta$ ) e são denominadas células Th3 (MOSMANN \& SAD, 1996).

De maneira geral, o perfil Th1 gera respostas imunes celulares e o Th2 respostas humorais. A resposta imune celular é mediada por macrófagos e células citotóxicas $\mathrm{CD}^{+}$e é normalmente dirigida contra parasitas intracelulares. Já a resposta imune humoral é mediada por linfócitos $B$, sendo normalmente dirigida a microorganismos extracelulares. As células CD4 ${ }^{+}$ participam dos dois tipos de resposta imune. Cabe enfatizar, no entanto, que, 
muitas vezes, a resposta imune contra determinados patógenos não reflete uma polarização clara dentro de um perfil Th1 ou Th2, mostrando a participação de ambos os tipos de citocinas (PAUL et al.,1994).

Desde a descoberta das sub-populações celulares Th1 e Th2, tem sido intensa a procura de marcadores de superfície específicos que permitissem diferenciar os linfócitos polarizados em uma ou outra direção. Recentemente tem sido descrito, em humanos, que os linfócitos com perfil Th2 expressam as moléculas CD30 e CCR3 na sua superfície, sendo que as células com perfil funcional Th1 não expressam estes marcadores (D'ELIOS et al., 1997; SALLUSTO et al., 1997).

A expressão diferencial de isoformas do antígeno linfocitário CD45 tem sido também utilizada como um possível marcador. CD45 é uma proteína tirosina fosfatase própria das células nucleadas de origem hematopoiética que pode ser expressa em diferentes isoformas, como resultado do "splicing" alternativo dos exons 4, 5 ou 6 (também denominados A, B e C). A utilização do CD45RB como possível marcador de diferenciação Th1 e Th2 por células $\mathrm{CD}^{+}$teve como base os trabalhos de BOTTOMLY et al. (1989), que mostravam que as células $\mathrm{T} \mathrm{CD} 4^{+}$produtoras de IL-2 tinham um fenótipo CD45RB ${ }^{\text {high }}$, enquanto que as $\mathrm{T} \mathrm{CD4} 4^{+}$produtoras de IL-4 tinham um fenótipo CD45RB ${ }^{\text {low }}$. Em concordância com estes resultados, POWRIE et al., 1994, mostraram que a população $\mathrm{CD}^{+}{ }^{+} \mathrm{CD} 45 \mathrm{RB}^{\text {high }}$ protege contra Leishmania major, parasita intracelular cuja destruição pelo sistema imune do hospedeiro depende de citocinas Th1. De forma análoga, D'IMPÉRIO LIMA et al. (1996) observaram que durante a infecção aguda pelo Plasmodium chabaudi os camundongos produzem altos níveis de IFN- $\gamma$ e pouca IL-4, sendo que nesta fase da doença as células $\mathrm{CD}^{+}$têm um fenótipo $\mathrm{CD}_{4} \mathrm{RB}^{\text {high }}$ predominante; nos camundongos que sobrevivem à infecção por este parasita, entretanto, o fenótipo dos linfócitos $\mathrm{CD}^{+}$muda para $\mathrm{CD} 45 \mathrm{RB}{ }^{\text {low }}$ e os animais passam a produzir mais IL-4 e pouco IFN- $\gamma$.

Contudo, para outros pesquisadores, a expressão de algumas isoformas de CD45 é indicativo do estado de maturação das células $C D 4^{+}$e não de uma polarização Th1/Th2. Desta forma, células "naive" teriam um fenótipo $\mathrm{CD} 4 \mathrm{RB}^{\text {high }}$ e células de memória, um fenótipo CD45RB ${ }^{\text {low }}$ (GRIFFIN \& ORME, 
1994), enquanto o fenótipo das células $C D 4^{+}$efetoras não estaria totalmente esclarecido.

Até o momento se desconhece qual o ligante extracelular da molécula CD45, e qual a participação das diferentes isoformas na ativação linfocitária. Porém, a geração de linhagens de camundongos deficientes da proteína CD45 permitiu demonstrar que a expressão desta molécula é importante para o desenvolvimento linfocitário (YAKURA, 1994) e para uma sinalização eficiente através dos receptores antigênicos dos linfócitos $T$ e $B$ (OKUMURA \& THOMAS, 1995).

Muitos autores têm proposto que o padrão de resistência ou susceptibilidade à infecção pelo $T$. cruzi está relacionado ao tipo de citocinas produzidas com participação destacada das citocinas Th1, responsáveis por promover a resistência (SILVA et al., 1992; HOFT et al., 1993; MINOPRIO et al., 1993; REED et al., 1994). Assim, a resistência ao parasita depende de citocinas tais como o IFN- $\gamma$, TNF- $\alpha$, IL-12 e GM-CSF, enquanto IL-10, IL-4 e TGF- $\beta$ promoveriam a susceptibilidade. A seguir, descrevemos sumariamente, a participação das diferentes citocinas na infecção pelo T. cruzi.

A IL-2 é um fator de crescimento para diferentes tipos celulares estando envolvida na proliferação de células T e células NK. Além disso, a IL-2 induz a síntese de múltiplas citocinas por linfócitos T e de IFN- $\gamma$ por células NK (ABBAS et al.,1994). Na infecção pelo T. cruzi verifica-se que, ao contrário do IFN- $\gamma$, que é produzido em quantidades significantes nas fases aguda e crônica, a IL-2 é produzida apenas de maneira transitória no início da infecção (HARELLBELLAM et al., 1983; TARLETON, 1988; SOONG \& TARLETON, 1994 e ZHANG \& TARLETON, 1996).

Vários mecanismos imunossupressores que afetam direta ou indiretamente a produção de IL-2 têm sido propostos para explicar a presença efêmera desta citocina na infecção chagásica. SOONG \& TARLETON (1994) propuseram que a baixa produção de IL-2 durante a infecção pelo $T$. cruzi pode estar ligada, possivelmente, a um efeito inibitório na regulação da transcrição 
dos genes desta citocina. As prostaglandinas (PGs) podem estar relacionadas a esta imunossupressão, uma vez que a adição de um inibidor de prostaglandinas, a indometacina, em culturas estimuladas com ConA, induz o aumento da produção de IL-2 (HAREL-BELLAN et al., 1985; TARLETON, 1988). O óxido nítrico (NO) pode também estar envolvido na supressão de IL-2, uma vez que linfócitos $T$ humanos ativados em presença desta substância apresentam uma diminuição da produção não só de IL-2 mas também de IFN $\gamma$, IL-5, IL-10 e IL-4 (BAUER et al., 1997).

De acordo com TARLETON (1993), a supressão de IL-2 na doença de Chagas é interessante quando analisada em um contexto imunopatológico, uma vez que uma supressão similar tem sido observada em outras doenças autoimunes; em ambos os casos, esta supressão não acontece por falta de células T capazes de secretar IL-2 ou pela ausência de cofatores como IL-1; células supressoras têm sido identificadas em ambos os casos e a produção normal de IL-2 pode ser restabelecida in vitro estimulando as células T com combinações de éster forbol e ionóforo de cálcio $\left(\mathrm{Ca}^{2+}\right)$ ou deixando as células em repouso por 48-72 horas (VIA \& SHEARER, 1988; KROEMER \& WICK,1989).

A IL-12 é produzida principalmente por macrófagos, agindo sozinha ou em sinergismo com a IL-2. É necessária para intensificar a produção de IFN- $\gamma$ pelas células T e NK, nas quais induz também a produção de TNF- $\alpha$, GM-CSF e IL-2 (KOBAYASHI et al.,1989; CHAN et al.,1991). Também induz a ativação de células "killer" ativadas por citocinas (LAK) e de células $\mathrm{CD}^{+}$citotóxicas (TRINCHIERI \& SCOTT, 1995). Além disto, esta citocina está envolvida na diferenciação de células $\mathrm{CD}^{+}$na direção Th1 (MANETTI et al.,1993; WU et al., 1993; MANETTI et al., 1994). Na doença de Chagas, esta citocina parece desempenhar um papel fundamental na fase precoce da infecção, uma vez que animais tratados com anticorpos anti-IL-12 têm um aumento da parasitemia e mortalidade (ALIBERTI et al., 1996). Desta maneira, a IL-12 produzida por macrófagos infectados determinaria a ativação de células NK, as quais, através da produção de IFN- $\gamma$, induziriam a ativação de macrófagos levando à 
produção de NO e destruição intracelular dos parasitas (ALIBERTI et al.,1996; ABRAHAMSOHN \& COFFMAN, 1996; CARDILLO et al., 1996).

O IFN- $\gamma$ tem sido correlacionado com a resistência e o controle do parasita na fase aguda da infecção pelo T. cruzi (JAMES et al., 1982; PLATA et al., 1984; PLATA et al., 1987; WIRTH et al., 1985; REED, 1988;). Diversos modelos têm demonstrado que camundongos resistentes secretam significantes quantidades de IFN- $\gamma$, enquanto que camundongos suscetíveis secretam predominantemente IL-4 e IL-10 (SILVA et al., 1992; MINOPRIO et al., 1993; HOFT et al., 1993; REED et al., 1994). O IFN- $\gamma$ está envolvido na ativação de macrófagos, induzindo-os a expressar moléculas de classe II do $\mathrm{CPH}$ e a secretar radicais de oxigênio e nitrogênio, ambos dotados de potente atividade microbicida (MUNOZ-FERNANDEZ et al.,1992). Tem sido relatado que o NO produzido em animais infectados está relacionado à resistência e ao controle da parasitemia (GAZZINELLI et al., 1992; VESPA et al.,1994).

O IFN- $\gamma$ está envolvido na mudança de classe de imunoglobulina para IgG2a e IgG3 (SNAPPER et al., 1987 e 1992) e induz nos macrófagos aumento de expressão de receptores para a porção Fc de IgG (WILSON \& FINBLOOM, 1992). Esta citocina é ainda responsáve,I indiretamente, por promover a diferenciação de células $\mathrm{CD} 4^{+} \mathrm{TH}_{0}$ na direção Th1, ao inibir a proliferação de células Th2 (PAUL \& SEDER, 1994) e por ser um importante estimulador da secreção de IL-12 por macrófagos ativados (KUBIN et al., 1993). Na infecção pelo $T$. cruzi, as células T sofrem supressão para produção de IL-2 e não para IFN- $\gamma$ (NABORS \& TARLETON, 1991), apesar das duas citocinas terem sido classificadas como do tipo Th1.

Sub-populações de linfócitos $\mathrm{T}$, como células NK, poderiam estar envolvidas na produção de IFN- $\gamma$. No início da infecção, previamente à ativação das células $T$, as células NK parecem ser as principais responsáveis pela produção desta citocina (CARDILLO et al., 1996), enquanto que mais adiante, as células $\mathrm{T}, \mathrm{CD} 4^{+}$e $\mathrm{CD} 8^{+}$, passariam a ter um papel proeminente. No entanto, em ensaios de dupla marcação com anticorpos para caracterizar in situ as populações produtoras desta citocina, ZHANG \& TARLETON, (1996b) observaram que os maiores produtores de IFN- $\gamma$ no baço de animais 
infectados, são células com fenótipo TCR $\alpha \beta^{+}$Thy-1 ${ }^{+}$CD4- CD8- A importância destas células $T$ duplo negativas na imunidade frente ao parasita ainda não foi totalmente esclarecida (TARLETON, 1991).

O TNF- $\alpha$ é uma citocina produzida por macrófagos, células T, células NK e outras populações celulares. Esta citocina é um mediador da imunidade natural e adquirida, com um amplo espectro de funções, destacando seu envolvimento no processo inflamatório no qual promove o recrutamento e ativação de fagócitos. Quando age sobre os macrófagos, induz a sua ativação, estimulando a produção de NO (GREEN et al., 1990; LANGERMANS et al., 1992). O TNF- $\alpha$ tem um papel importante no controle da infecção murina pelo T. cruzi, ativando macrófagos para a destruição intracelular do parasita. Entretanto, o TNF $\alpha$ também parece estar envolvido na caquexia e na morte durante a fase aguda, sendo um elemento fundamental da reação inflamatória tissular. O seu papel em relação ao IFN- $\gamma$ na ativação de macrófagos é ainda controvertido. GOLDEM \& TARLETON, (1991) reportaram que TNF- $\alpha$ não sinergiza com IFN- $\gamma$ no aumento da capacidade tripanosomicida; outros trabalhos, porém, mostram que estas duas citocinas atuam sinergicamente na ativação de macrófagos aumentando a destruição de parasitas intracelulares (MUÑOZ-FERNANDEZ et al., 1992).

O GM-CSF é uma citocina responsável pela proliferação, diferenciação e ativação de células precursoras de granulócitos e macrófagos (GASSON, 1991; HAMILTON, 1993). É produzida por monócitos, macrófagos, linfócitos T e células endoteliais (METCALF, 1992). O GM-CSF está envolvido no controle da transcrição e da secreção de várias citocinas e também da expressão de moléculas de classe II do $\mathrm{CPH}$ e de receptores para Fc (COLEMAN et al., 1988; FISHER et al., 1988). Esta citocina exerce um importante efeito sobre a capacidade tumoricida, microbicida e "burst" oxidativo dos macrófagos humanos e murinos (DENIS, 1991). O envolvimento de GM-CSF na infecção por T. cruzi é ainda pouco entendido, no entanto, em ensaios in vitro, esta citocina diminui os níveis de infecção tanto em macrófagos não ativados, 
quanto em macrófagos ativados via IFN- $\gamma$ (REED et al., 1987, GRABSTEIN et al., 1986). Recentemente, OLIVARES FONTT et al. (1996) observaram que, animais tratados com anticorpos monoclonais anti-GM-CSF têm uma resistência diminuída à infecção pelo $T$. cruzi.

A IL-10, citocina desativadora de macrófagos, é indiretamente responsável por diminuir a produção de IFN- $\gamma$ e serve para amortecer os efeitos potencialmente lesivos da ativação de macrófagos sobre os tecidos do hospedeiro (FIORENTINO et al.,1991). Os linfócitos CD4 ${ }^{+}$(Th2), os linfócitos B1 e os queratinócitos (O'GARRA et al., 1992) são, juntamente com os macrófagos (MOSMANN, 1991), responsáveis pela produção de IL-10. A IL-10 inibe a expressão nos macrófagos de moléculas de classe II e de moléculas coestimuladoras B7, fazendo com que estas células tenham sua capacidade de apresentar antígenos reduzida (DE WAAL MALEFYT et al., 1991). Também é responsável pela diminuição da síntese de IL-2 (DE WAAL MALEFYT et al.,1993), IFN- $\gamma$ (HSU et al.,1990) e IL-12 (D'ANDREA et al.,1993) e está envolvida na supressão da proliferação de células T (DE WAAL MALEFYT et al., 1991; TAGA \& TOSATO, 1992). Ensaios in vitro demonstram que a IL-10 é capaz de inibir a destruição intracelular do T. cruzi (GAZINELLI et al., 1992; SILVA et al., 1992). Camundongos "knock out" de IL-10 controlam mais eficientemente a infecção por $T$. cruzi, reduzindo os níveis de parasitismo e determinando um aumento significante na secreção de IFN- $\gamma$, NO, TNF- $\alpha$ e IL12 (ABRAHANSOHN et al., 1996; HUNTER et al., 1997). Entretanto, a despeito deste efeito protetor, os animais deficientes em IL-10 sucumbem mais rapidamente à infecção pelo $T$. cruzi, o que é um provável resultado do efeito incontrolado das citocinas pro-inflamatórias na ausência de IL-10.

A IL-4 é uma citocina que atua em diferentes estágios de ativação, proliferação e diferenciação das células B. Na proliferação destas células, esta linfocina, que pode ser secretada pelas células T $\mathrm{CD}^{+}$e mastócitos, atua como fator co-estimulador juntamente com o ligante de CD40 (BANCHEREAU et al., 1991). Também é responsável, em camundongos, pela mudança de classe de imunoglobulinas de $\lg$ M para $\lg G 1$ e $\lg E$, e pela indução de moléculas de 
classe II em células B (ZURAWSKI \& DE VRIES, 1994). A IL-4 está envolvida na diferenciação de linfócitos T na direção Th2 (PAUL \& SEDER, 1994). Juntamente com a IL-10 e o TGF- $\beta$, tem sido considerada como uma citocina que promoveria a suscetibilidade dos camundongos na infecção pelo $T$. cruzi. Níveis alterados de IL-4 têm sido detectados no baço de camundongos infectados com $T$. cruzi ao longo da fase crônica, mas não durante a fase aguda (ZHANG \& TARLETON, 1996b). Em outras infecções por parasitas intracelulares, tais como a leishmaniose e a hanseníase, a resposta exacerbada de IL-4 leva a um agravamento acentuado da doença (SALGAME et al.,1991; PAUL \& SEDER, 1994).

O TGF- $\beta$ é uma citocina produzida por diversos tipos de células, tais como macrófagos, células NK e células $\mathrm{T}$. Tem propriedades imunossupressivas e anti-inflamatórias (KEHRL et al., 1991; RUSCETTI et al., 1993). Sua ausência em camundongos "knock out" resulta em uma inflamação difusa por células mononucleares em diversos órgãos vitais (CHRIST et al., 1994). O TGF- $\beta$ inibe in vitro a capacidade de macrófagos ativados por IFN- $\gamma$ em matar o T. cruzi (SILVA et al., 1991; GAZZINELLI et al., 1992) e a sua administração em camundongos infectados induz altas taxas de parasitemia e mortalidade (SILVA et al., 1991). ZHANG \& TARLETON (1996a) e ZHANG \& TARLETON (1996b) demonstraram que, o TGF- $\beta$ é produzido no coração e no baço durante todo o curso da infecção, tanto em modelos resistentes, quanto nos suscetíveis a infecção por $T$. cruzi. Estes resultados sugerem que esta citocina tem um importante papel na modulação da intensa e prolongada resposta inflamatória ao $T$. cruzi, limitando os danos tissulares causados pela inflamação.

\subsubsection{Mecanismos de patogênese}

Na doença de Chagas, o T. cruzi induz de maneira direta ou indireta uma série de alterações moleculares e morfológicas em diferentes tecidos e órgãos, das quais decorrem os quadros anátomo-clínicos que caracterizam a 
enfermidade. Diversos fatores atuam na patogênese da Doença de Chagas, determinando uma maior ou menor incidência de infiltrado inflamatório e de destruição tissular. Entre estes, alguns são inerentes ao T. cruzi, ligados ao seu polimorfismo, tropismo e constituintes antigênicos e outros estão relacionados ao hospedeiro, como constituição genética, idade, sexo, entre outros. Nota-se que os fatores patogênicos são múltiplos e em grande parte desconhecidos (TAFURI, 1987).

Três elementos podem estar envolvidos na patologia durante a infecção pelo T. cruzi: destruição celular conseqüente à quebra de ninhos do parasita, destruição celular que acompanha a resposta inflamatória e deficiência funcional, resultado da fibrose que acompanha a resolução da inflamação. Estes processos são simultâneos e podem atingir qualquer tecido ou órgão; entretanto, o coração, o tubo digestivo e o sistema nervoso são os principais e mais importantes alvos (LOPES \& CHAPADEIRO, 1997). Alguns mecanismos têm sido propostos para explicar como a resposta imune poderia determinar a disfunção dos órgãos atingidos. Estes incluem: i) a destruição direta do tecido muscular, ii) a perda de função muscular conseqüente à desnervação local, iii) a agregação plaquetária intravascular geradora de microinfartos, entre outros (TARLETON, 1993).

A hipótese mais aceitável para explicar a existência de inflamação no coração, tubo digestivo, e outros órgãos lesados seria a de uma reação inflamatória frente aos parasitas que colonizam estes órgãos. Nesta perspectiva, as lesões crônicas seriam geradas por uma contínua destruição do tecido infectado através de uma resposta inflamatória induzida pelo $T$. cruzi e mediada por clones linfocitários específicos para o parasita. Entretanto, a ausência de ninhos nas proximidades dos infiltrados levantou a hipótese da reação inflamatória não ser mediada por clones linfocitários específicos para o parasita, mas sim, por clones auto-reativos que reconheceriam antígenos próprios. Desta forma, o processo inflamatório crônico e a conseqüente destruição tissular passaram a ser considerados como resultado de um processo autoagressivo. Neste contexto de autoimunidade, diversos antígenos tissulares foram descritos nas duas últimas décadas como elementos alvo dos linfócitos T e B autorreativos, e diversos mecanismos, não excludentes, foram 
propostos como responsáveis pela indução de autorreatividade. Assim, foi sugerido que a perda de tolerância às estruturas próprias durante a infecção pelo $T$. cruzi seria o resultado: i) da persistente resposta inflamatória local; ii) da intensa ativação policlonal dos linfócitos nas fases aguda e crônica (MINOPRIO et al., 1989a e 1989b e VAN VOORHIS \& EISEN, 1989) e iii) da reatividade cruzada entre o parasita e antígenos próprios órgãos-específicos (SADIGURSKY et al., 1982; CUNHA-NETO et al., 1995).

RIBEIRO DOS SANTOS et al. (1992) sugeriram ser a autoimunidade o principal mecanismo implicado na gênese da miocardite crônica na doença de Chagas. Estes autores investigaram a autorreatividade contra o tecido cardíaco singênico in vivo, através de transplantes de coração de camundongos recémnascidos para a base da orelha de camundongos chagásicos crônicos ou de controles não infectados. Assim, não era observada rejeição em animais não infectados, enquanto que os animais crônicos rejeitavam prontamente o órgão transplantado. A rejeição parecia ser mediada por linfócitos $\mathrm{T} \mathrm{CD4}^{+}$e o estado de tolerância podia ser restabelecido com o tratamento in vivo com anticorpo monoclonal anti-CD4 antes dos transplantes.

A hipótese de autoagressão foi considerada nas últimas décadas como a mais provável para explicar a patologia chagásica. Recentemente, entretanto, foi reavaliada a participação do parasita como elemento alvo dos processos inflamatórios tissulares. Isto foi resultado dos avanços tecnológicos que permitiram a detecção in situ de antígenos ou DNA do parasita. Assim, HIGUCHI et al.(1993) mostraram que, em humanos, a intensidade da miocardite se correlaciona diretamente com os níveis de antígenos de T. cruzi no coração detectados por imuno-histoquímica. Por outro lado, VAGO et al. (1996), utilizando técnicas de PCR (do inglês, Polymerase Chain Reaction) detectaram a presença do $T$. cruzi no esôfago unicamente naqueles pacientes chagásicos que apresentavam um quadro clínico de patologia digestiva. TARLETON et al. (1997) mostraram, posteriormente, que corações neonatais transplantados para camundongos crônicos não exibiam quaisquer sinais de rejeição, sobrevivendo por mais de um ano totalmente livres de inflamação e de parasitas, como foi determinado por análise de PCR in situ. Entretanto, quando se injetavam parasitas diretamente nos corações transplantados em animais 
crônicos, observava-se uma rápida e intensa resposta inflamatória, sugerindo que o parasita é um fator preponderante e indispensável para o estabelecimento das lesões tissulares.

O conjunto destes resultados indica que, qualquer que seja o mecanismo envolvido na destruição das células do hospedeiro, o parasitismo tissular na fase crônica parece ter um papel importante no desenvolvimento da patologia. Se esta correlação só foi recentemente observada, deve-se ao fato dos métodos utilizados até então, para detectar a presença de parasitemias na fase crônica (xenodiagnóstico e hemocultura), serem essencialmente não quantitativos (TARLETON, 1993).

Tomando como base o conjunto destes resultados, que sugerem a existência de uma correlação entre o parasitismo na fase crônica e a patologia, decidimos avaliar quais os fatores responsáveis pelo nível de parasitismo na fase crônica. Neste trabalho, analisamos se este seria um reflexo da carga parasitária durante a fase aguda da doença. 
Este projeto tem como objetivo definir se a carga parasitária na fase aguda afeta:
a) a parasitemia,
b) a patologia,
c) e a resposta imune,

na fase crônica da doença de Chagas experimental. 


\subsection{Abordagem experimental}

Os objetivos deste projeto foram abordados infectando-se camundongos com diferentes inóculos de T.cruzi, possibilitando assim a obtenção de grupos submetidos a alta e baixa carga parasitária na fase aguda da infecção. Posteriormente, estes grupos foram analisados na fase crônica sob diversos parâmetros:

a) Análise da parasitemia, direta ou indireta através de ensaio de transferência do sangue de animais crônicos para animais imunossuprimidos pelo tratamento com ciclofosfamida.

b) Análise do baço:

- quantificação do número de células esplênicas.

- quantificação do número total de células esplênicas (PFCs) que secretam anticorpos dos diferentes isotipos (IgM, IgG1, IgG2a, IgG2b e IgG3) através do ensaio de ELISASPOT.

- quantificação dos níveis de linfocinas (IL-2, IL-4, IL-10 e IFN $\gamma$ ) através do ensaio de ELISA de esplenócitos estimulados com ConA.

- análise da celularidade diferencial esplênica, através do ensaio de citometria de fluxo para diferentes marcadores $\left(C D 4^{+}, \mathrm{CD}^{+}\right.$, $\mathrm{CD}_{45 \mathrm{R}^{+}}$(B220), CD45RB(16a), CD45RB(23g2) e CD5 ${ }^{+}$).

c) Análise da reatividade sorológica frente a antígenos de T.cruzi.

d) Análise histopatológica do coração e músculo estriado esquelético. 


\subsection{Animais}

Nos experimentos desta tese foram utilizados camundongos fêmeas das linhagens $A / J$ e $C A F_{1}$, de 6 a 8 semanas de idade, obtidos do Biotério de Animais Isogênicos do Departamento de Imunologia, ICB/USP.

\subsection{Manutenção das cepas de $T$. cruzi}

A cepa $Y$ de Trypanosoma cruzi (SILVA \& NUSSENZWEIG, 1953) foi originalmente obtida no Centro de Imunologia (Instituto Butantã) e foi mantida em camundongos $A / J$ por meio de passagens semanais do sangue infectado. Resumidamente, o sangue contendo os parasitas foi colhido em solução de citrato de sódio a 3,8\% por punção do plexo oftálmico. O número de parasitas na suspensão foi determinado por contagem em hemocitômetro (câmera de Neubauer) e ajustado para $4 \times 10^{5}$ parasitas $/ \mathrm{mL}$. Camundongos normais foram inoculados pela via intraperitoneal (i.p.) com $0.25 \mathrm{~mL}$ da suspensão contendo $1 \times 10^{5}$ parasitas.

A cepa CL de $T$. cruzi (BRENER \& CHIARI, 1963) foi gentilmente cedida pelo Prof. Dr. Momtchilo Russo e foi mantida em nosso laboratório de maneira semelhante à descrita acima. No caso desta cepa, os repiques eram feitos a cada duas semanas e o inóculo utilizado continha $1 \times 10^{4}$ parasitas.

\subsection{Modelos de infecção e tratamento quimioterápico específico}

Modelo I: Infecção com parasitas da cepa $\mathrm{Y}$ de $T$. cruzi em camundongos resistentes. Camundongos $\mathrm{CAF}_{1}$ foram infectados por via i.p. com 5, 50, 5.000 e 50.000 formas sanguíneas da cepa $Y$ de $T$. cruzi. 
Modelo II: Infecção com parasitas da cepa $Y$ de $T$. cruzi em camundongos suscetíveis. Camundongos $\mathrm{A} / \mathrm{J}$ foram infectados por via i.p. com 50 ou 50.000 formas sanguíneas. No sexto dia após a infecção, os animais dos grupos infectados e controles foram tratados com uma dose única, de $1 \mathrm{~g} / \mathrm{kg}$ de peso corporal, de Benzonidazol (Rochagan, Roche), via intra-gástrica (i.g.).

Modelo III: Infecção com parasitas da cepa $\mathrm{Y}$ de $T$. cruzi em camundongos suscetíveis. Camundongos $\mathrm{A} / \mathrm{J}$ foram infectados por via i.p. com 1.000 (baixa dose) ou 100.000 (alta dose) formas sanguíneas. No sexto dia após a infecção, os animais dos grupos infectados e controles foram tratados com uma dose única, de $1 \mathrm{~g} / \mathrm{kg}$ de peso corporal, de Benzonidazol (Rochagan, Roche), via i.g.

Modelo IV: Infecção com parasitas da cepa CL de $T$. cruzi em camundongos suscetíveis. Camundongos $\mathrm{A} / \mathrm{J}$ foram infectados por via i.p. com 1.000 (baixa dose) ou 100.000 (alta dose) formas sanguíneas da cepa CL. No décimo primeiro dia após a infecção, os animais dos grupos infectados e controles foram tratados com uma dose única, de $1 \mathrm{~g} / \mathrm{kg}$ de peso corporal, de Benzonidazol (Rochagan, Roche), via i.g.

\subsection{Avaliação das parasitemias na fase aguda}

As parasitemias foram avaliadas na fase aguda da infecção através do exame a fresco de gota de sangue obtida pela secção da cauda. As determinações de parasitemia foram feitas pelo método descrito por BRENER (1962).

\subsection{Avaliação das parasitemias na fase crônica}

As parasitemias na fase crônica foram avaliadas através de uma técnica semi-quantitativa altamente sensível, onde o sangue dos animais crônicos é 
sub-inoculado, ou seja, transferido para camundongos normais que posteriormente são tratados com Ciclofosfamida (ALVAREZ et al., 1991) (Fig.1). Os animais crônicos foram sangrados individualmente usando uma solução de Citrato de Sódio a 3,8\%. Alíquotas de 0,1 mL de sangue da cada animal crônico foram injetadas via i.p. em três animais normais, os quais receberam dois dias mais tarde uma dose única, de $200 \mathrm{mg} / \mathrm{Kg}$ de peso, de Ciclofosfamida (Enduxan, Abbott), via i.p. A partir do sexto dia após a transferência do sangue, os animais transferidos foram avaliados, conforme descrito por BRENER, (1962), para verificar a presença de parasitas circulantes. Um animal crônico foi considerado ter parasitemia positiva quando seu sangue resultava em pelo menos uma transferência positiva. Os níveis de parasitemia crônica dos grupos experimentais foram estimados pela freqüência de transferências positivas por grupo e pela freqüência de transferências positivas considerando unicamente os animais com parasitemia positiva em cada grupo.

\subsection{Citometria de fluxo (FACS)}

A técnica de citometria de fluxo foi utilizada para a análise das populações linfocitárias no baço de animais crônicos. As células foram obtidas por rompimento mecânico do baço dos camundongos em meio D-MEM (Dubecco's modified eagle medium) (Gibco BRL, New York, USA) suplementado com 3\% de soro fetal bovino (FCS), que sera chamado de meio completo. Estas células foram duplamente marcadas em suspensão com anticorpos de rato anti-CD5 e anti-B220, ou anti-la e anti-CD8, ou anti-CD4 (todos Gibco BRL) e anti-CD45RB (clones 16A e 23G2) (Pharmingen, San Diego, USA), marcados com PE (ficoeritrina) ou FITC (fluoresceína). Essas células foram mantidas em meio DMEM, distribuídas em placas de cultura de 96 orifícios com fundo em $U$ (Corning, New York, USA) na concentração de 0,5X106 células /100 $\mu \mathrm{L} /$ por orifício. Após a centrifugação (5 minutos, $4{ }^{\circ} \mathrm{C}, 200 \mathrm{~g}$ ), o sobrenadante foi desprezado e os anticorpos monoclonais marcados foram adicionados em concentrações ótimas previamente estabelecidas. As placas de cultura foram 
Animal crônico

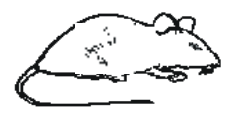

Transferência de sangue de animal crônico p/ três animais normais $(0.1 \mathrm{ml} /$ animal $)$
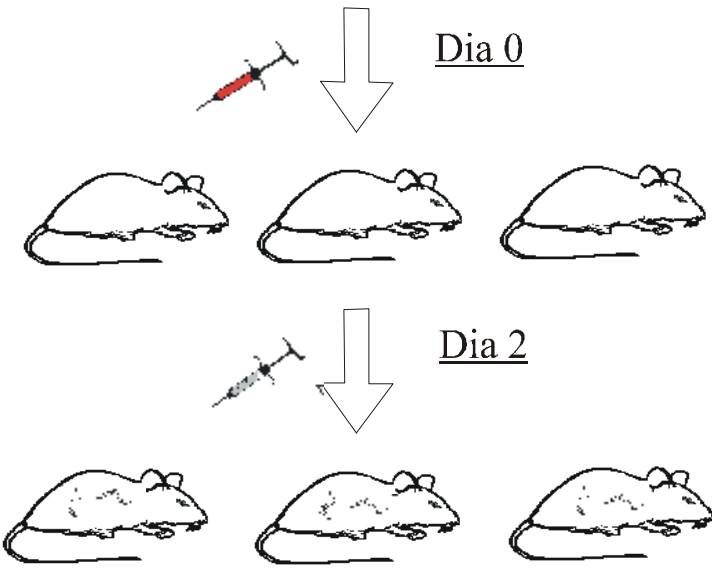

Tratamento com ciclofosfamida via I.P.

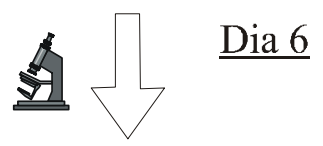

Início da avaliação das parasitemias

Figura 1- Esquema do ensaio de transferência para avaliação das parasitemias na fase crônica. 
mantidas a $4^{\circ} \mathrm{C}$ por 30 minutos em local com pouca luminosidade. A seguir, as células foram lavadas uma vez com meio de cultura e duas vezes com salina tamponada com fosfato (PBS), sendo posteriormente ressuspendidas em 0,5 $\mathrm{mL}$ de uma solução de paraformaldeído a 0,1\%. As suspensões de células marcadas foram analisadas em um citofluorímetro de fluxo (FACScan) (Becton Dicikinson, Mountain View, USA) de acordo com a intensidade de fluorescência (FL1 e FL2) e a dispersão do feixe luminoso (FSC). A distribuição no FSC (Forward scatter) das células com fluorescência positiva foi analisada a fim de determinar a porcentagem de células blásticas nas diferentes subpopulações linfocitárias

\subsection{Ensaio de ELISASPOT}

O ensaio de ELISASPOT foi realizado segundo o método descrito por CZERKINSKY et al. (1983) e SEDGWICK \& HOLT (1983). Placas de ELISA (Costar, Cambridge, MA, USA) foram incubadas durante 18 horas (h), a $4^{0} \mathrm{C}$ com anticorpos de cabra anti-imunoglobulina total de camundongos (10 $\mu \mathrm{g} / \mathrm{mL})$. As placas foram saturadas, por 60 minutos, com PBS contendo $1 \%$ de gelatina. Após lavagens sucessivas com PBS, volumes de $100 \mu \mathrm{l}$ de meio completo contendo diluições decrescentes de células esplênicas (a partir de $10^{5}$ células) foram distribuídas nas placas de ELISA. As suspensões celulares foram mantidas em banho de gelo. A seguir, as culturas de células foram incubadas, durante 6 horas, a $37^{\circ} \mathrm{C}$, em atmosfera contendo $5 \%$ de $\mathrm{CO}_{2}$. Após este período, as células foram lisadas com um pulso rápido de água destilada e, a seguir, as placas foram lavadas por 3 vezes em PBS contendo 0,05\% de Tween 20 (Sigma, St. Louis, MO, USA). A presença de células secretoras de anticorpos foi revelada adicionando-se anticorpos de cabra anti-IgM, anti-lgG1, anti-IgG2a, anti-IgG2b e anti-IgG3 de camundongo conjugados a biotina, seguido por avidina conjugado à fosfatase alcalina (diluída 1/1000 em PBSTween com 1\% de BSA). Todos os anticorpos e conjugados foram adquiridos da Southern Biotechnologies Associates (Birmingham, USA) e utilizados em 
concentrações ótimas previamente estabelecidas. Um volume de $50 \mu \mathrm{L}$ por orifício de 5-bromo, 4-cloro, 3-indolil fosfato (5-BCIP, 5-bromo chloro 3-indolyl phosphate, Sigma) diluído na concentração de $1 \mathrm{mg} / \mathrm{ml}$ de tampão 2-amino 2metil 1-propanol (AMP, 2-amino 2-methyl 1-propanol, E. Merck A. G., Darmastadt, Alemanha) foi usado como substrato. As placas foram incubadas, por $2 \mathrm{~h}$ a $37^{\circ} \mathrm{C}$, em atmosfera úmida e o número de manchas ("spots") por orifício foi quantificado com o auxílio de uma lupa. Os números de células secretoras de anticorpos por $10^{6}$ células foram determinados em orifícios contendo entre 20 a 50 "spots". Os números de "spots" por baço para cada especificidade ou isotipo foram calculados levando em consideração os números totais de células esplênicas, determinados após contagem em hemocitômetro.

\subsection{Obtenção dos sobrenadantes de cultura de células esplênicas}

Suspensões celulares individuais provenientes do baço de camundongos $\mathrm{A} / \mathrm{J}$ controles e infectados com baixa $\left(10^{3}\right)$ e alta dose $\left(10^{5}\right)$ foram obtidas, como descrito anteriormente, e cultivadas em placas de 24 orifícios (Costar), para obtenção dos sobrenadantes de cultura. Utilizou-se meio DMEM suplementado com $7 \%$ de FCS, $5.5 \times 10^{-5} \mathrm{M}$ de 2-Mercapto-etanol (ME), $2 \mathrm{mM}$ de Piruvato, $100 \mathrm{U} / \mathrm{mL}$ de Penicilina-G potássica e $100 \mu \mathrm{g} / \mathrm{mL}$ de Sulfato de Estreptomicina. As células foram ajustadas para a concentração de $5 \times 10^{6}$ células $/ \mathrm{mL}$, estimuladas com $2,5 \mu \mathrm{g} / \mathrm{mL}$ de concanavalina $A$ (ConA) e mantidas a $37^{\circ} \mathrm{C} \mathrm{em}$ atmosfera com $5 \%$ de $\mathrm{CO}_{2}$. Os sobrenadantes foram coletados após 24,48 e $72 \mathrm{~h}$ totais de cultivo, respectivamente e armazenados a $-80^{\circ} \mathrm{C}$ para posterior dosagem de citocinas. 


\subsection{Dosagem de citocinas nos sobrenadantes de cultura celular}

As citocinas foram quantificadas em sobrenadantes de culturas estimuladas por ConA. As dosagens foram realizadas através da técnica de ELISA Sandwich de captura, empregando anticorpos monoclonais de rato anticitocina de camundongo. Placas de ELISA (Costar) foram incubadas $18 \mathrm{~h}$, a $4^{\circ} \mathrm{C}$, com anticorpos de rato anti-IFN $\gamma$, anti-IL-4, anti-IL-2, ou anti-IL-10 de camundongos $(4 \mu \mathrm{g} / \mathrm{mL})$ (Pharmingen), diluídos em tampão de sensibilização $\left(0.1 \mathrm{M} \mathrm{NaHCO}_{3}\right)$. Após este período, as placas foram bloqueadas com $200 \mu \mathrm{L}$ de gelatina (Merck) a 1\%, durante 1 hora. Posteriormente as placas foram lavadas por 3 vezes em PBS contendo 0,05\% de Tween 20 (Sigma) e em seguida, $50 \mu \mathrm{L}$ do padrão (citocinas recombinantes, Pharmingen) e dos sobrenadantes a serem testados foram acrescentados, diluídos em meio completo. As placas foram incubadas durante $18 \mathrm{~h}$ a $4^{\circ} \mathrm{C}$. Após este período as placas foram lavadas mais uma vez em PBS-Tween e 50 $\mu \mathrm{L}$ dos anticorpos monoclonais específicos para cada citocina conjugados à biotina (Pharmingen) foram adicionados, utilizando como diluente PBS contendo 0,05\% de Tween e 1\% de BSA (Sigma). Posteriormente, as placas foram incubadas durante 45 minutos à temperatura ambiente. Após esta etapa as placas foram lavadas 3 vezes em PBS-Tween e em seguida incubadas por 30 minutos com $50 \mu \mathrm{L}$ do conjugado enzimático (streptoavidina marcada com peroxidase, Gibco BRL) diluído 1/1000 em PBS-Tween com $1 \%$ de BSA. Por fim, as placas foram lavadas mais uma vez, como já descrito, e $50 \mu \mathrm{l}$ de uma solução contendo o substrato $\mathrm{H}_{2} \mathrm{O}_{2}$ e o cromógeno OPD (O-Fenilenodiamina, Sigma), dissolvidos em tampão citrato 0,028M / fosfato de sódio $0.044 \mathrm{M}$, foram colocados. A reação foi bloqueada com ácido cítrico $0,2 \mathrm{M}$ e a leitura realizada a 450nm em leitor de ELISA MR 5000 (Dynatech). As concentrações de citocinas de cada amostra (ng/mL) foram calculadas utilizando-se a parte linear da curva padrão de citocinas recombinantes (Pharmingen). 


\subsection{Obtenção de formas tripomastigotas de cultura e preparo de antígeno de T.cruzi}

As formas tripomastigotas de T.cruzi (cepa $Y$ ), foram obtidas do sobrenadante de monocamadas de células LLC-MK 2 infectadas (American Type Culture Collection - ATCC - CCL7.1). Os parasitas provenientes destas culturas foram lavados 3 vezes em PBS estéril, por centrifugação (1900 g, 20 $\min , 4^{0} \mathrm{C}$ ) e ressuspendidos na concentração de $10^{9}$ parasitas $/ \mathrm{mL}$. Em seguida, cada alíquota foi submetida a 10 ciclos de congelamento e descongelamento como descrito por CUROTTO-DE-LAFAILLE et al. (1990). As amostras foram armazenadas a $-80^{\circ} \mathrm{C}$ e a concentração proteica foi da ordem de $2,5 \mathrm{mg} / \mathrm{mL}$ para as suspensões de $10^{9}$ parasitas $/ \mathrm{mL}$

\subsection{Dosagem de anticorpos específicos anti-T. cruzi}

Para dosagem dos anticorpos específicos anti- $T$. cruzi no soro de camundongos cronicamente infectados utilizamos o ensaio de ELISA descrito por AVRAMEAS et al. (1979), com algumas modificações. Para a sensibilização das placas, foram utilizados $50 \mu \mathrm{L}$ de antígeno de $T$. cruzi $(20 \mu \mathrm{g} / \mathrm{mL})$ diluído em tampão de carbonato/bicarbonato $0.05 \mathrm{M} \mathrm{pH}$ 9.6. As placas foram incubadas por $18 \mathrm{~h}$ a $4^{0} \mathrm{C}$. Após 3 lavagens sucessivas, de 5 minutos cada uma, com PBS contendo 0,05\% de Tween 20 (Sigma Chemical Co.), as placas foram saturadas, por 60 minutos, com 200 $\mu \mathrm{L}$ de PBS-Tween contendo $3 \%$ de BSA. Após novas lavagens, foram adicionados a cada orifício $50 \mu \mathrm{l}$ das diluições de cada soro, feitas em PBS-Tween contendo 1\% de BSA (diluições: $1: 200,1: 400$ e 1:800 para IgM e IgG1; 1:3200, 1:6400 e 1:25600 para IgG2a; 1:100, 1:200 e 1:400 para IgG3 e IgG2b), seguida de incubação de $1 \mathrm{~h}$ à temperatura ambiente. Após novos ciclos de lavagem, a presença de anticorpos específicos contra o parasita foi revelada adicionando-se anticorpos de cabra anti-IgM, anti-IgG1, anti-IgG2a, anti-lgG2b e anti-lgG3 de camundongo conjugados à biotina, seguido por adição de avidina conjugado á 
peroxidase (Gibco BRL), diluída 1/1000 em PBS-Tween com 1\% de BSA. Por fim, as placas foram lavadas mais uma vez como já descrito, e $50 \mu \mathrm{L}$ de uma solução contendo o substrato $\mathrm{H}_{2} \mathrm{O}_{2}$ e o cromógeno OPD dissolvidos em tampão citrato $0,028 \mathrm{M} /$ fosfato de sódio $0.044 \mathrm{M}$ foram colocados. A reação foi bloqueada com ácido cítrico $0,2 \mathrm{M}$ e a leitura foi realizada a 450nm em leitor de ELISA MR 5000 (Dynatech). As concentrações ( $\mu \mathrm{g} / \mathrm{mL})$ dos anticorpos IgG2a e IgG1 foram estimadas por padronização indireta, segundo FERREIRA et al. (1996), com pequenas alterações. Em cada placa de ELISA, alguns dos orifícios foram sensibilizados com soro de cabra anti-imunoglobulina total de camundongo $(10 \mu \mathrm{g} / \mathrm{mL})$ e incubados com diluições seriadas (de 10 a 0,078ng/well, em duplicatas) de um padrão de isotipo de imunoglobulina de camundongo. A correspondência entre os valores de O.D. e a concentrações de IgG1, ou IgG2a, foi estabelecida pela equação matemática da parte linear da curva padrão dos isótipos de imunoglobulinas. As concentrações ( $\mu \mathrm{g} / \mathrm{mL})$ de anticorpos específicos para o parasita, de cada soro, foram calculadas aplicando os valores de D.O. (Densidade Ótica) das amostras séricas nesta equação. Diluições das amostras com D.O. abaixo ou acima da parte linear de uma curva com soro hiperimune de $T$. cruzi não foram consideradas. Todos os anticorpos, incluindo os conjugados e padrões, foram adquiridos de Southern Biotechnologies Associates (Birmingham, USA).

\subsection{Histopatologia}

Os animais foram anestesiados, sangrados através de punção cardíaca até a morte e seus órgãos foram imediatamente coletados e fixados por $24 \mathrm{~h}$ em solução de formaldeído a 10\%, sendo posteriormente incluídos em blocos de parafina. O coração foi cortado sagitalmente em duas partes, cada uma contendo as quatro cavidades. Seis cortes sagitais de $5 \mu \mathrm{m}$, não consecutivos, foram obtidos do coração e do músculo esquelético (quadríceps), corados por hematoxilina-eosina e posteriormente analisados na sua totalidade através de microscopia ótica. Para mensuração das lesões, utilizou-se um microscópio Olympus (Olympus Optical Co, Tokyo, Japan) acoplado a uma camêra de vídeo 
conectada a um sistema de análise de imagens computadorizado (BIOSCAN OPTIMAS, Bioscan Inc. Edmonds, WA). Após a calibração do sistema com uma régua Zeiss de $2 \mathrm{~mm}$, cada lesão foi delimitada com uma caneta eletrônica e sua área imediatamente calculada. A soma das áreas dos infiltrados foi calculada para cada camundongo e os valores individuais foram expressos em $\mu \mathrm{m}^{2}$ de infiltrado inflamatório por $\mathrm{mm}^{2}$ de área examinada.

\subsection{Análise estatística}

Para análise comparativa entre os grupos experimentais, adotamos os testes $t$ de Student para duas variáveis assumindo igual variância e MannWhitney. Os níveis de significância foram definidos como sendo iguais ou inferiores a 0,05 $(p<0,05)$, e em alguns casos iguais ou inferiores a 0,1 $(p<0,1)$. 


\section{RESULTADOS}




\subsection{Escolha do modelo experimental}

A princípio, nosso objetivo foi obter um modelo de infecção onde fossem estabelecidos grupos experimentais claramente diferenciados em relação à carga parasitária na fase aguda. De início pensamos que isto seria possível utilizando uma linhagem de camundongo de conhecida resistência à cepa $Y$ do T. cruzi, a linhagem $\mathrm{CAF}_{1}$.

\subsubsection{Modelo I: Camundongos $\mathrm{CAF}_{1}$ infectados com 5, 50, 5.000 e 50.000 T. cruzi.}

Neste modelo preliminar utilizamos camundongos isogênicos $\mathrm{CAF}_{1}$ infectados com 5, 50, 5.000 e 50.000 parasitas. A princípio este protocolo pareceu ideal para definir grupos com carga parasitárias diferentes. Entretanto, os resultados mostraram que a carga parasitária na fase aguda varia muito pouco em função da dose, sendo que a variação entre os grupos se refletia principalmente em um deslocamento no tempo dos picos de parasitemia (Fig.2). Como o objetivo inicial do projeto, era obter grupos com diferenças significantes em relação a cargas parasitárias, este modelo se mostrou inapropriado.

\subsubsection{Modelo II: Camundongos A/J infectados com 50 e $\mathbf{5 0 . 0 0 0}$ T. cruzi, seguido de tratamento com Benzonidazol no $6^{\circ}$ de infecção.}

Devido às dificuldades encontradas no primeiro modelo experimental, pensamos que dificilmente poderíamos obter grupos com diferentes cargas parasitárias, utilizando protocolos que deixassem a infecção na sua evolução natural. Entretanto, consideramos que este objetivo poderia ser atingido interrompendo as curvas parasitêmicas em animais infectados com diferentes doses de $T$. cruzi. Para avaliar esta possibilidade, realizamos várias experiências utilizando camundongos isogênicos $A / J$, linhagem suscetível à infecção por $T$. cruzi, nos quais induzimos o controle da parasitemia mediante 


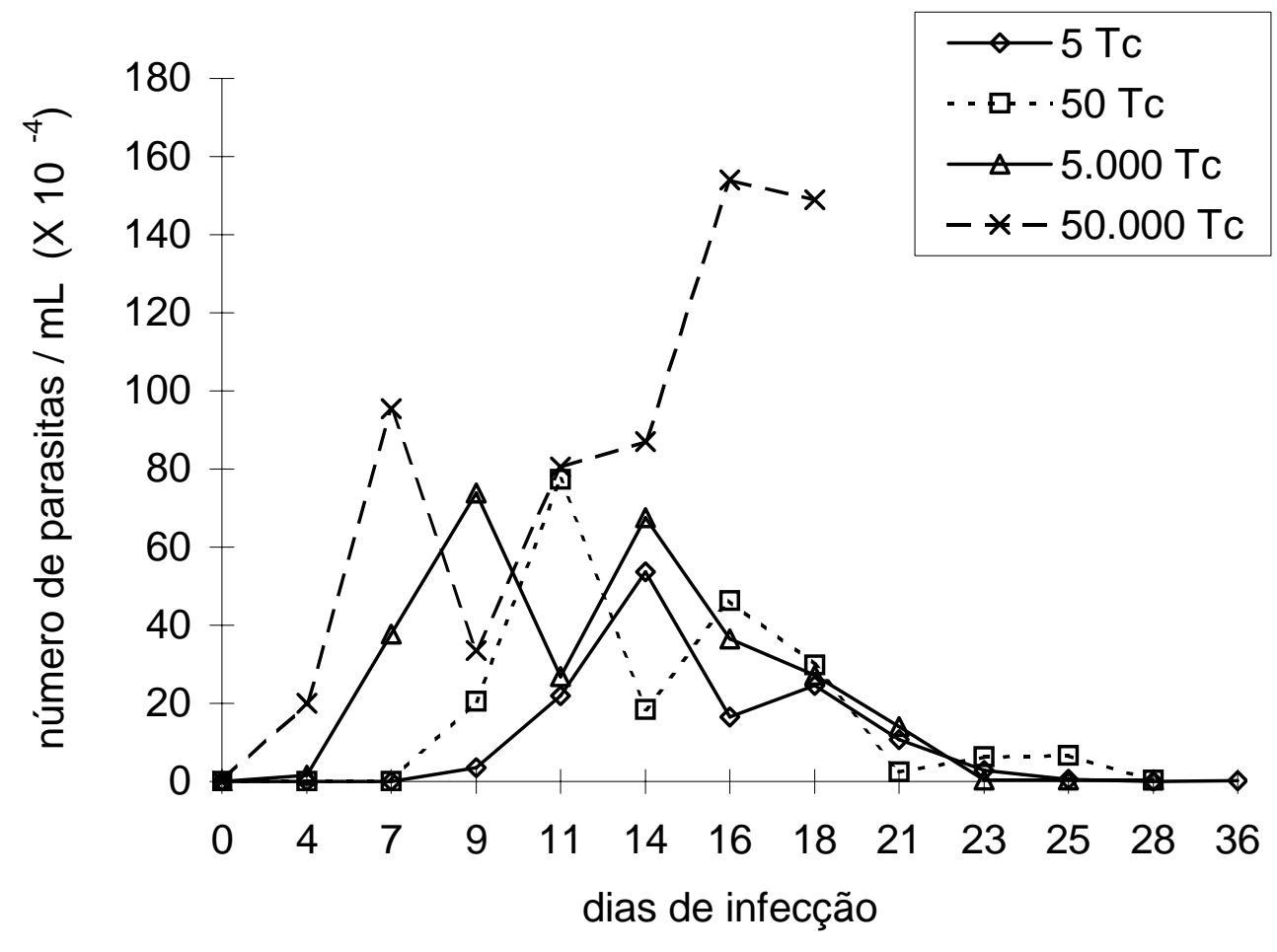

Figura 2- Curva de parasitemia de animais $\mathrm{CAF}_{1}$, infectados via intraperitoneal com 5, 50, 5.000 e 50.000 formas tripomastigotas da cepa $Y$ de T. cruzi (Tc). Os valores correspondem à média aritmética de 5 animais por grupo. 
tratamento quimioterápico específico com Benzonidazol. Desta maneira, grupos de camundongos foram infectados com 50 (baixa dose) e 50.000 (alta dose) parasitas e tratados no $6^{0}$ dia de infecção com uma dose única, via intragástrica de Benzonidazol. Este protocolo a princípio pareceu ser adequado, uma vez que diferenciava os grupos nitidamente em relação a carga parasitária nos primeiros dez dias da fase aguda (Fig.3); entretanto, esta diferenciação deixou de ser eficaz, devido ao aparecimento de um pico tardio de parasitemia no grupo infectado com baixa dose, por volta do dia 27 de infecção. Este comportamento da curva parasitêmica no grupo infectado com baixo inóculo, se deve possivelmente a um fraco estímulo antigênico, resultante do baixo número de parasitas no dia do tratamento com Benzonidazol, o que limita a ativação do sistema imune para o controle eficiente da parasitemia.

\subsubsection{Modelo III: Camundongos A/J infectados com 1.000 e $100.000 \mathrm{~T}$. cruzi, seguido de tratamento com Benzonidazol no 6으 dia de infecção.}

Devido ao resultado inesperado obtido anteriormente, repetiu-se 0 experimento aumentando os inóculos infectantes para 1.000 parasitas (baixa dose) e 100.000 parasitas (alta dose), mantendo-se o tratamento com Benzonidazol no $6^{0}$ dia de infecção. Neste experimento (Fig.4), e em outros realizados com o mesmo protocolo, conseguimos resultados satisfatórios, uma vez que os grupos estavam claramente diferenciados em relação à carga parasitária na fase aguda e não foram observados picos tardios de parasitemia em nenhum dos grupos experimentais.

Com base nos resultados descritos acima, escolhemos a infecção de grupos de camundongos A/J com inóculos de 1.000 e 100.000 T. cruzi (cepa Y), seguido de tratamento com Benzonidazol no $6^{\underline{0}}$ dia, como modelo experimental adequado a propiciar diferentes níveis de carga parasitária na fase aguda da doença. 


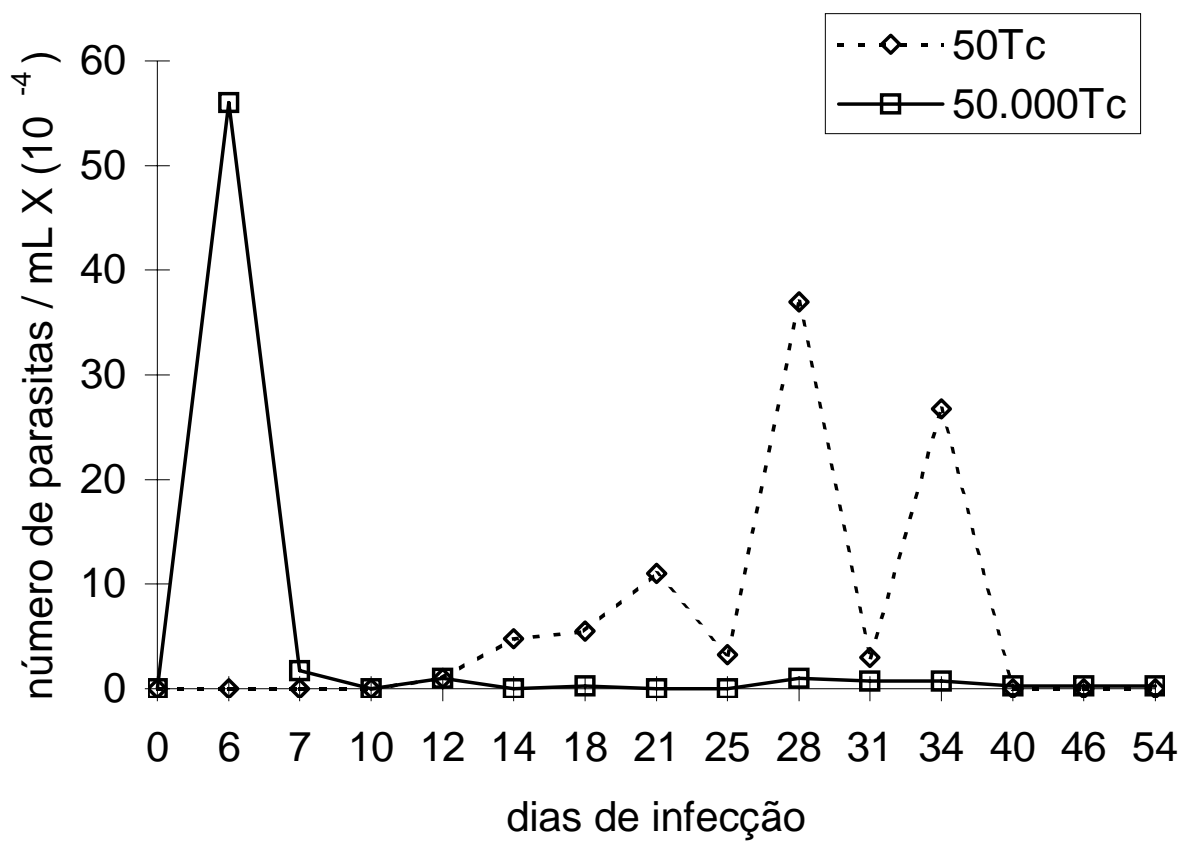

Figura 3- Curva de parasitemia de animais $A / J$ infectados via intraperitoneal com 50 ou 50.000 formas tripomastigotas da cepa $Y$ de $T$. cruzi (Tc). No $6^{\circ}$ dia de infecção, ambos os grupos foram tratados com uma dose única de $1 \mathrm{~g} / \mathrm{Kg}$ de peso corporal de Benzonidazol, via intragástrica. Os valores correspondem à média aritmética de 5 animais por grupo. 


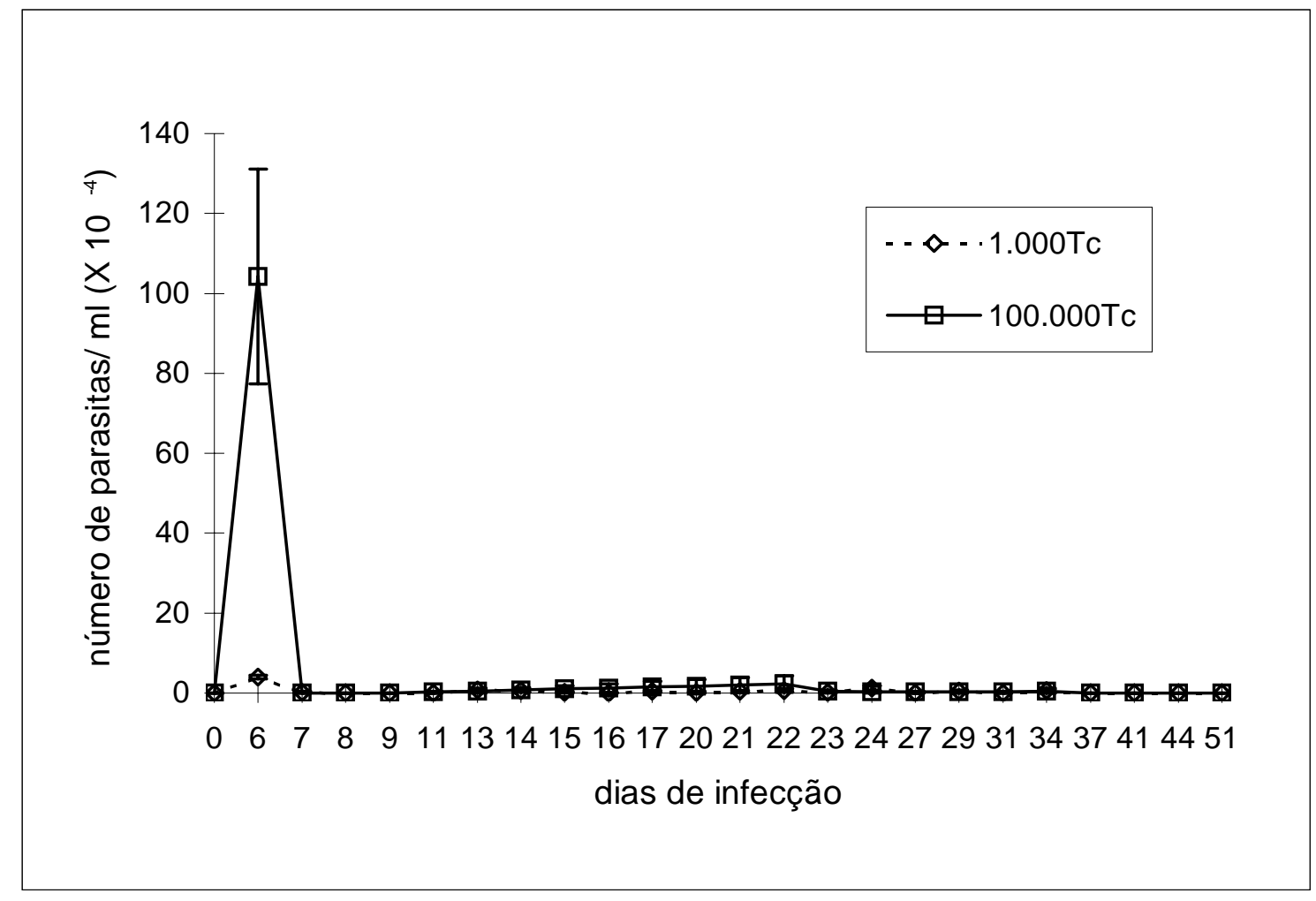

Figura 4- Curva de parasitemia de animais $A / J$ infectados via intraperitonial com $10^{3}$ (baixa dose) ou $10^{5}$ (alta dose) formas tripomastigotas da cepa $Y$ de T. cruzi (Tc). No 6ํํㅁ dia de infecção, os animais de ambos os grupos foram tratados com uma dose única de $1 \mathrm{~g} / \mathrm{Kg}$ de peso corporal de Benzonidazol, via intragástrica. Os valores correspondem à média aritmética de 5 animais por grupo \pm desvio padrão. 


\subsection{Parasitemia na fase crônica}

Após um ano de infecção, as parasitemias dos camundongos infectados com alto e baixo inóculos foram avaliadas através de um ensaio de subinoculação semi-quantitativo (ALVAREZ et al., 1991). Os camundongos infectados com alta dose ( $10^{5}$ parasitas) mostraram uma parasitemia residual na fase crônica superior à dos animais do grupo infectado com baixa dose $\left(10^{3}\right.$ parasitas) (Tabela I). Estas diferenças foram evidentes quando expressas em relação ao número de animais crônicos que determinavam transferências positivas, e também quando calculamos as porcentagens de transferências positivas de cada grupo. Resultados similares foram obtidos em animais crônicos infectados com alto ou baixo inóculo de parasitas da cepa CL (Tabela II). Mais ainda, se entre os animais infectados com $10^{3}$ e $10^{5}$ tripomastigotas (cepa $Y$ ) considerarmos apenas aqueles que mostraram parasitemia positiva na fase crônica, observamos que nos animais do grupo de alta dose, $73,3 \%$ das transferências foram positivas, contra $48,1 \%$ no grupo de baixa dose. Estes resultados sugerem que os camundongos com parasitemia positiva no grupo de alta dose têm mais parasitas circulantes que os animais positivos do grupo infectado com baixa dose.

\subsection{Análise histopatológica}

Para a análise histopatológica dos grupos crônicos infectados com alta e baixa dose de parasitas utilizamos o coração e o músculo esquelético. Os animais infectados com alta dose mostraram ter maior grau de miocardite e miosite que os animais infectados com baixa carga (Tabela III e fig. 5). Os infiltrados inflamatórios foram classificados como focais e difusos e eram constituídos predominantemente por células mononucleares, estando muitas vezes presentes em regiões perivasculares. Exemplos de infiltrados com diferentes intensidades são mostrados na figura 6. O grupo infectado com alto inóculo apresentou um significativo aumento no número de fibras degeneradas no músculo esquelético. Não foram encontrados ninhos de parasitas, e em 
Tabela I- Quantificação dos níveis de parasitemia na fase crônica da infecção pelo T.cruzi (cepa Y) ${ }^{a}$.

$\begin{array}{ccccc}\text { grupos }^{\mathrm{b}} & \text { dias } & \text { \% de animais crônicos com } & \% \text { de transferências } & \% \text { de transferências positivas } \\ \text { infecção } & \text { transferências positivas } & \text { positivas por grupo } & \text { dos animais com } \\ \text { inforitemias positivas } & \end{array}$

$\begin{array}{lccccr}\text { Exp. } 1 & 10^{3} \text { parasitas } & 315 & 41.66 \%(5 / 12) & 19.44 \%(7 / 36) & 7 / 15 \\ \text { Exp. 2 } & \prime & 326 & 42.85 \%(3 / 7) & 19.04 \%(4 / 21) & 4 / 9 \\ \text { Exp.3 } & \prime & 476 & 20.00 \%(1 / 5) & 13.33 \%(2 / 15) & 2 / 3 \\ & & & & \text { TOTAL } & 13 / 27(48,1 \%) \\ \text { Exp. } 1 & 10^{5} \text { parasitas } & 315 & 70.00 \%(7 / 10) & 43.30 \%(13 / 30) & 13 / 21 \\ \text { Exp. 2 } & \prime & 326 & 85.71 \%(6 / 7) & 76.19 \%(16 / 21) & 16 / 18 \\ \text { Exp.3 } & \prime & 476 & 70.00 \%(7 / 10) & 50.00 \%(15 / 30) & 15 / 21 \\ & & & & \text { TOTAL } & 44 / 60(73,3 \%)\end{array}$

${ }^{a}$ As parasitemias foram avaliadas através do ensaio semi-quantitativo de sub-inoculação. Volumes de sangue de $0,1 \mathrm{~mL}$ de cada animal crônico foram transferidos para três animais não infectados.

${ }^{\text {b }}$ Camundongos foram infectados com $10^{3}$ ou $10^{5}$ formas tripomastigotas de $T$. cruzi. No $6^{0}$ dia de infecção todos os animais foram tratados com Benzonidazol e as suas parasitemias verificadas nos tempos indicados acima. Na tabela são mostrados os resultados de três experimentos com grupos pareados de alto e baixo inóculo.

${ }^{c}$ Nesta análise foram considerados exclusivamente os animais crônicos de cada grupo que resultaram em transferências positivas. 
Tabela II- Quantificação dos níveis de parasitemia na fase crônica da infecção por T.cruzi (cepa CL) ${ }^{\text {a }}$.

\begin{tabular}{lccc}
\hline grupos & & & \\
& dias & de de animais & $\%$ de \\
crônicos com & transferências \\
positivas & positivas por \\
& & & grupo \\
$10^{3}$ parasitas & 84 & $12,50 \%(1 / 8)$ & $6,25 \%(1 / 16)$ \\
$10^{5}$ parasitas & $"$ & $75,00 \%(6 / 8)$ & $37,5 \%(6 / 16)$ \\
\hline
\end{tabular}

${ }^{a}$ As parasitemias foram avaliadas através do ensaio semi-quantitativo de sub-inoculação. Volumes de sangue de 0,1 mL de cada animal crônico foram transferidos para dois animais não infectados.

${ }^{\text {b }}$ Camundongos foram infectados com $10^{3}$ ou $10^{5}$ formas tripomastigotas de T. cruzi. No dia $11^{\circ}$ dia de infecção todas os animais foram tratados com Benzonidazol e as suas parasitemias foram verificadas nos tempos indicados acima. 
Tabela III- Análise histopatológica do coração e do músculo esquelético de animais crônicos infectados com formas tripomastigotas da cepa Y de T.cruzi.

\begin{tabular}{|c|c|c|c|c|c|c|}
\hline \multirow{2}{*}{$\begin{array}{l}\text { grupos } \\
\text { crônicos }^{2}\end{array}$} & \multicolumn{4}{|c|}{ Coração $^{b}$} & \multicolumn{2}{|c|}{ Músculo estriado } \\
\hline & miocardite & endocardite & pericardite & Total & miosite $^{b}$ & $\begin{array}{c}\text { fibras } \\
\text { degeneradas }^{c}\end{array}$ \\
\hline $10^{3}$ parasitas & $179.1 \pm 117.6$ & $18.7 \pm 14.3$ & $53.2 \pm 51.1$ & $251.7 \pm 111.7$ & $106.2 \pm 72.4$ & $5.1 \pm 3.4$ \\
\hline $10^{5}$ parasitas & $414.9 \pm 169.9^{8}$ & $22.5 \pm 22.4$ & $62.7 \pm 36.0$ & $500.1 \pm 199.0^{*}$ & $402.7 \pm 309.3^{*}$ & $12.3 \pm 8.6^{*}$ \\
\hline
\end{tabular}

a Camundongos foram infectados com $10^{3}$ ou $10^{5}$ formas tripomastigotas de $T$. cruzi. No $\theta^{0}$ dia de infecção todos os animais foram tratados com Benzonidazol e, após um ano de infecçäo, sacrificados e seus órgãos coletados para análise histopatológica.

' Miocardite, endocardite, pericardite e miosite foram representadas pelas médias \pm desvio padrão dos valores individuais nos camundongos de um mesmo grupo (6 lâminas / animal), expressos em $\mu \mathrm{m}^{2}$ de infiltrado inflamatório $/ \mathrm{mm}^{2}$ do coração ou músculo estriado examinado.

${ }^{\mathrm{C}} \mathrm{A}$ incidência de fibras degeneradas no músculo estriado foi representada pelas médias \pm desvio padrão dos valores individuais nos camundongos de um mesmo grupo (6 lâminas / animal), expressos em número de fibras degeneradas / área total examinada. * p<0,05 comparado com o grupo infectado com $10^{3}$ parasitas (Mann-Whitney Test; $n$ : 7 camundongos por grupo). 


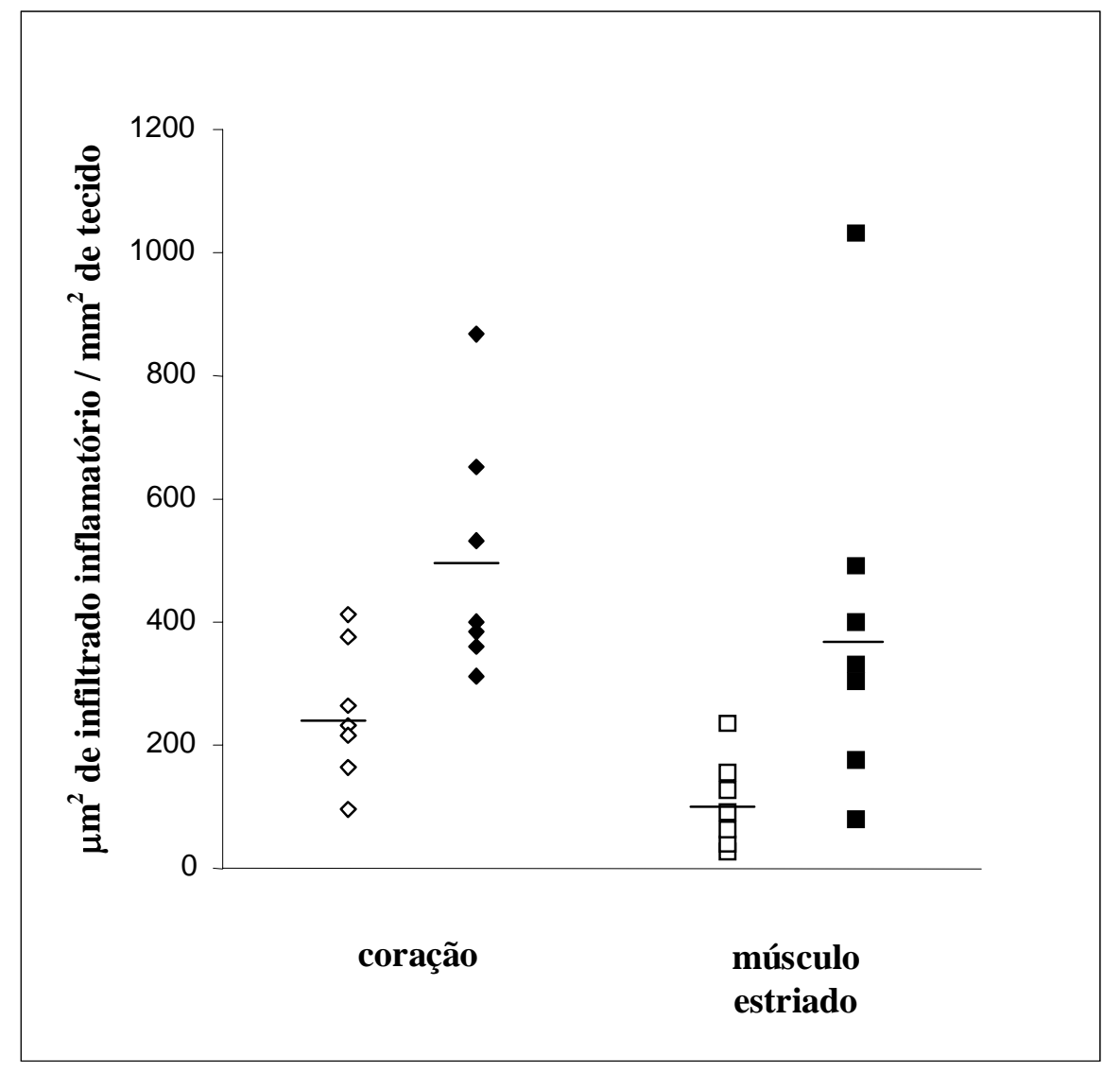

Figura 5- Análise morfométrica dos infiltrados inflamatórios do coração e músculo esquelético de animais submetidos a diferentes inóculos parasitários na fase aguda da infecção. Camundongos $\mathrm{A} / \mathrm{J}$ foram infectados via intraperitonial com $10^{3}$ (baixa dose, $\square \diamond$ ) ou $10^{5}$ (alta dose, - ) formas tripomastigotas da cepa $Y$ de $T$. cruzi. No $6^{\circ}$ dia de infecção, os animais de ambos os grupos foram tratados com uma dose única de $1 \mathrm{~g} / \mathrm{Kg}$ de peso corporal de Benzonidazol, via intragástrica. Um ano depois da infecção, os infiltrados foram quantificados como foi descrito nos materiais e métodos. 

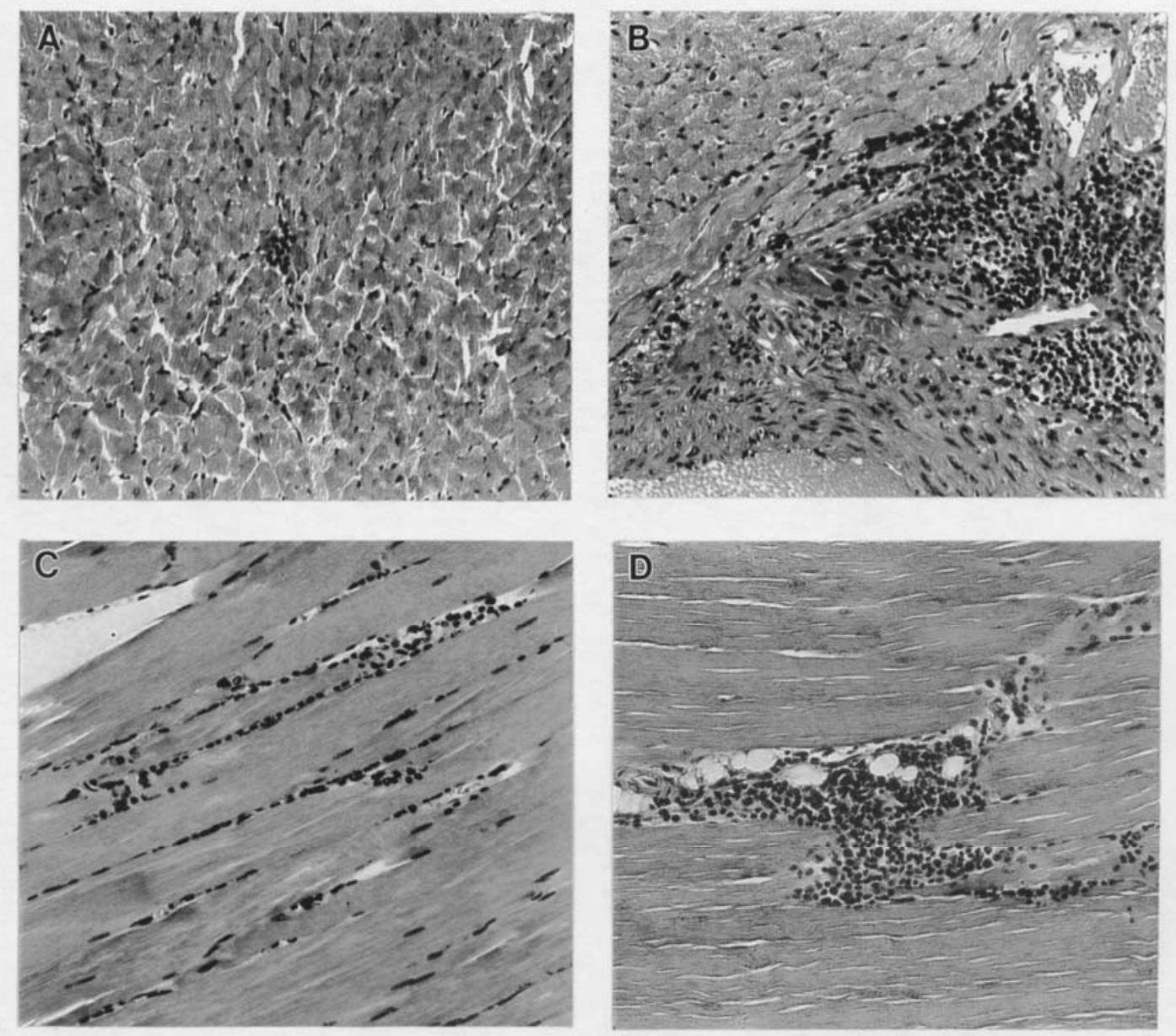

Figura 6- Exemplos de lesões no coração e no músculo estriado esquelético (quadrícepes) de camundongos infectados via intraperitonial com $10^{3}$ (baixa dose) ou $10^{5}$ (alta dose) formas tripomastigotas de T. cruzi (cepa $Y$ ) um ano depois da infecção. (A) Infiltrado discreto no ventrículo esquerdo do coração de um animal infectado com baixo inóculo. (B) Infiltrado ventricular intenso em um animal infectado com alto inóculo. (C) Infiltrado moderado difuso e (D) focal intenso no músculo de um animal infectado com alto inóculo. Aumento, 50X. 
nenhum órgão analisado foram observadas lesões severas, fato que já era esperado, uma vez que a patologia na fase crônica não é muita intensa. Os níveis de pericardite e endocardite entre os grupos experimentais não foram significantemente diferentes.

\subsection{Análise da celularidade esplênica}

Os baços dos animais crônicos foram analisados, uma vez que este é um dos principais órgãos envolvidos no sequestro dos parasitas da circulação. Um ano depois de serem infectados, os animais crônicos possuíam 2 ou 3 vezes mais células esplênicas que os animais do grupo controle (Fig. 7).

Foram observadas diferenças significativas em relação à celularidade esplênica entre os grupos infectados com alta e baixa dose, assim os animais apresentaram $47,43 \pm 20,08 \times 10^{6}, 92,08 \pm 30,55 \times 10^{6}$ e $126,96 \pm 55,56 \times 10^{6}$ células/ baço nos grupos controle, baixo e alto inóculo respectivamente.

\subsection{Análise das populações linfocitárias esplênicas}

Os ensaios de citometria de fluxo revelaram um aumento do número

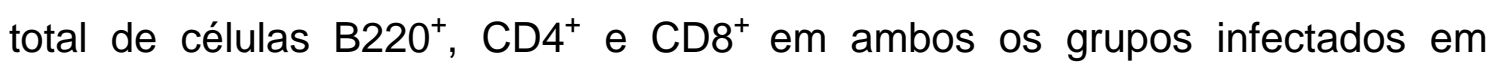
relação aos grupos controle (Fig. 8G, H e I). Comparando os grupos infectados, observamos que estes diferiam exclusivamente em relação ao número total de células $\mathrm{CD}^{+}$, não se observando diferenças nas populações $\mathrm{B}^{2} 20^{+}$e $\mathrm{CD} 4^{+}$. A análise de freqüências das populações linfocitárias revelou uma diminuição nas porcentagens das células $\mathrm{B}_{2} 2 \mathrm{O}^{+}$e $\mathrm{CD} 4^{+}$, mas não das células $\mathrm{CD} 8^{+}$, que foi melhor evidenciada no grupo infectado com alta dose (Fig.8A, B e C). Esta diminuição é decorrente de um intenso acúmulo no baço de uma população de células com fenótipo B220CD5 CD4 CD8 (Fig.9). Esta população mostrou-se particularmente aumentada no grupo infectado com alta dose (Fig. 9A). Muitas das células B220 ${ }^{\circ}{ }^{-}$são grandes, com granulosidade baixa e expressam moléculas de classe II ( $\left.\mathrm{Ia}^{+}\right)$(Fig. 9C). Além disso, estas células expressam 


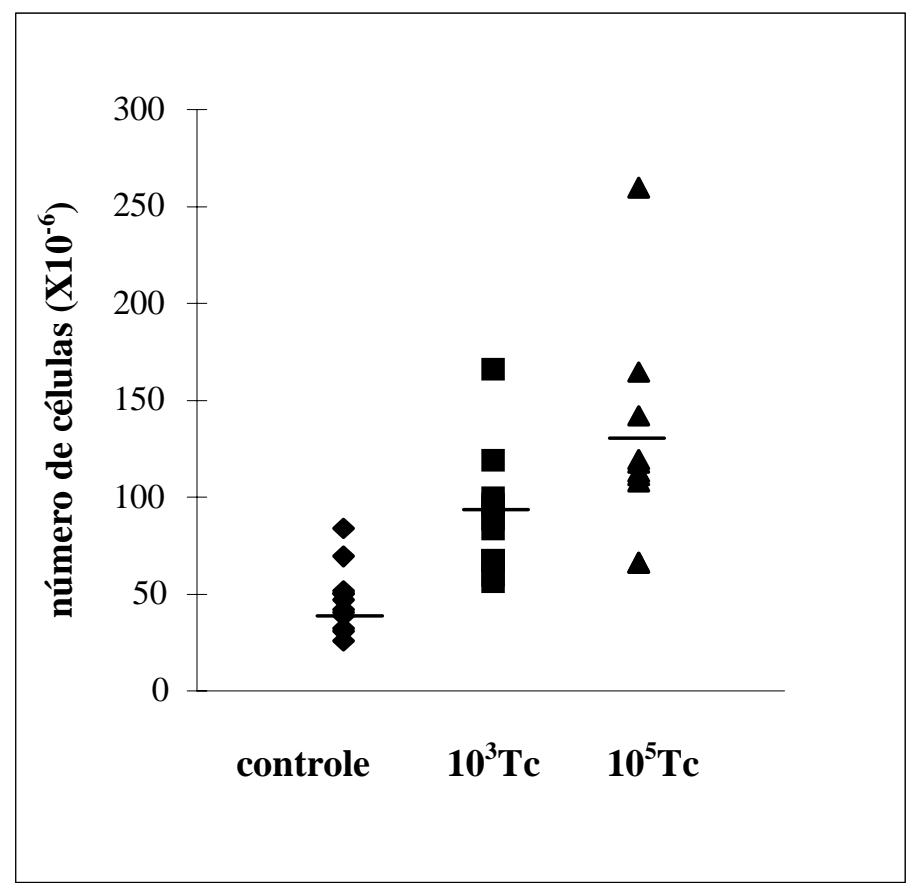

Figura 7- Número total de células do baço de camundongos controles e infectados com $10^{3}$ (baixa dose) e $10^{5}$ (alta dose) formas tripomastigotas da cepa $Y$ de T.cruzi (Tc). 


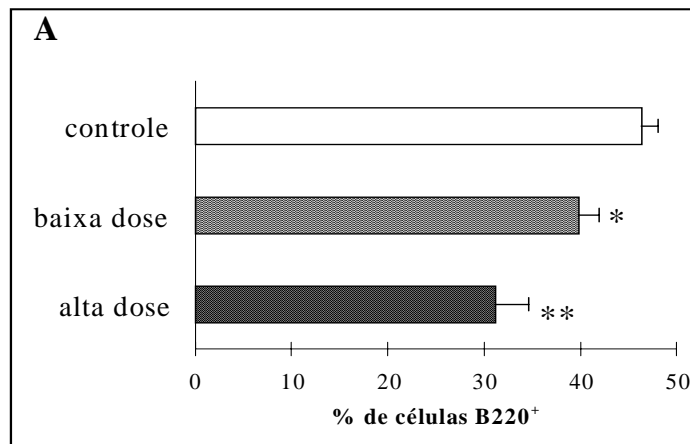

D

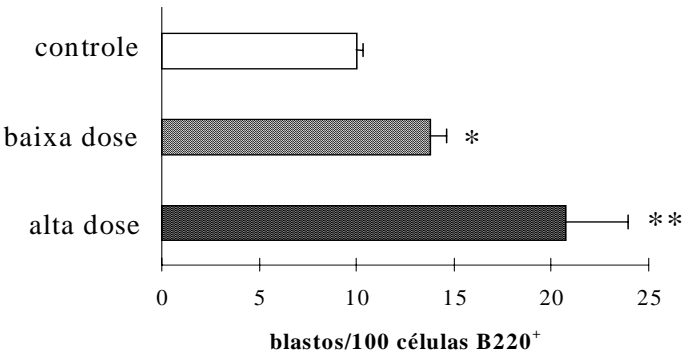

G

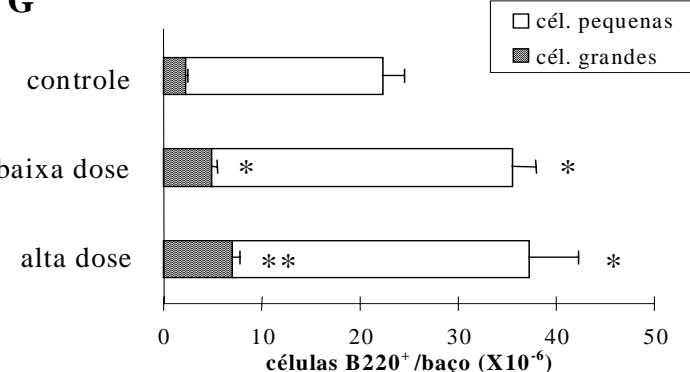

B

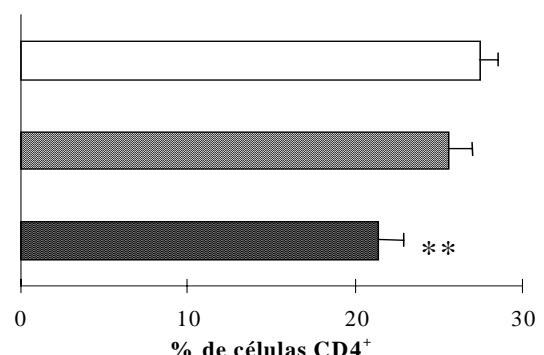

E

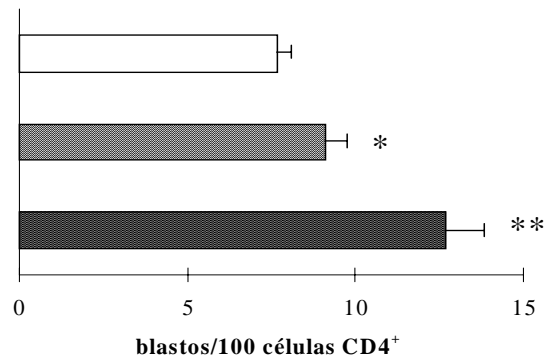

H

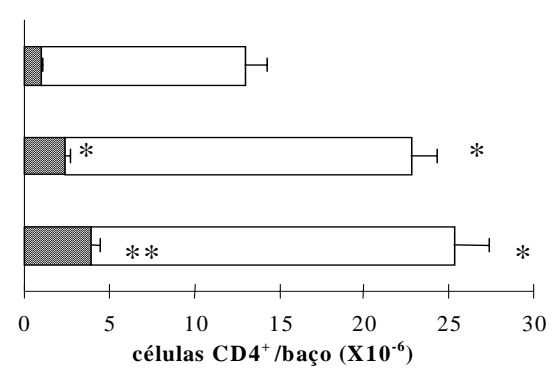

C

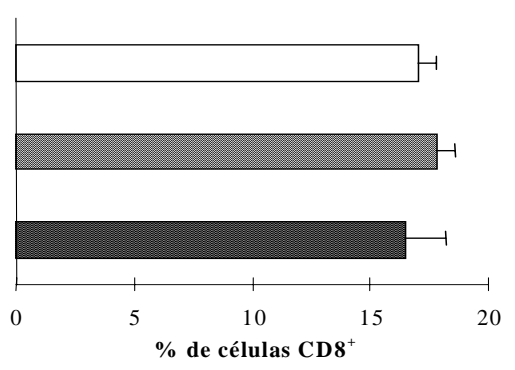

$\mathbf{F}$

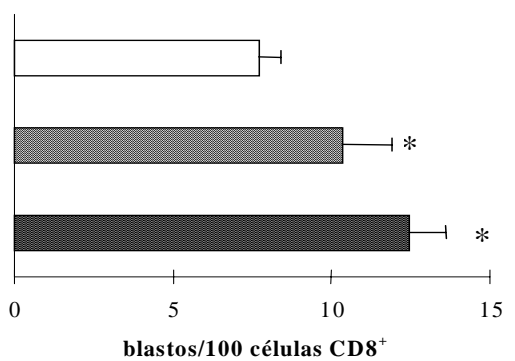

I

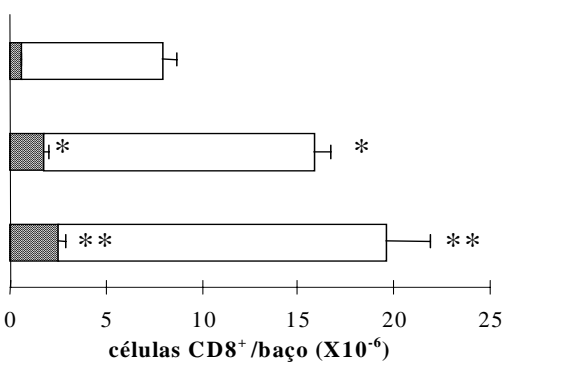

Figura 8- Análise por citometria de fluxo das sub-populações linfocitárias do baço de camundongos infectados via intraperitonial com $10^{3}$ (baixa dose) ou $10^{5}$ (alta dose) formas tripomastigotas da cepa $Y$ de $T$. cruzi. No $6^{-}$dia de infecção, os animais de ambos os grupos e os do grupo controle foram tratados com uma dose única de $1 \mathrm{~g} / \mathrm{Kg}$ de peso corporal de Benzonidazol, via intragástrica. Um ano depois da infecção, a freqüência de células $\mathrm{B}\left(\mathrm{B} 220^{+}\right), \mathrm{CD}^{+}$e $\mathrm{CD} 8^{+}$foram avaliadas (A-C). $\mathrm{O}$ número de células grandes foí calculados pela análise de FSC (forward scatter) na região de cada população linfocitária (D-F). O número total de células e o número total de células grandes por baço de cada população foi calculado considerando o número de células esplênicas (G-I). Cada barra representa a média \pm EP dos valores individuais de 10-11 camundongos. As médias de cada grupo foram comparadas através do teste $t$ de Student. ${ }^{*} p<0,05$ entre os grupos crônicos e controle; ** $p<0,05$ entre o grupo de alta dose e os outros dois grupos. 


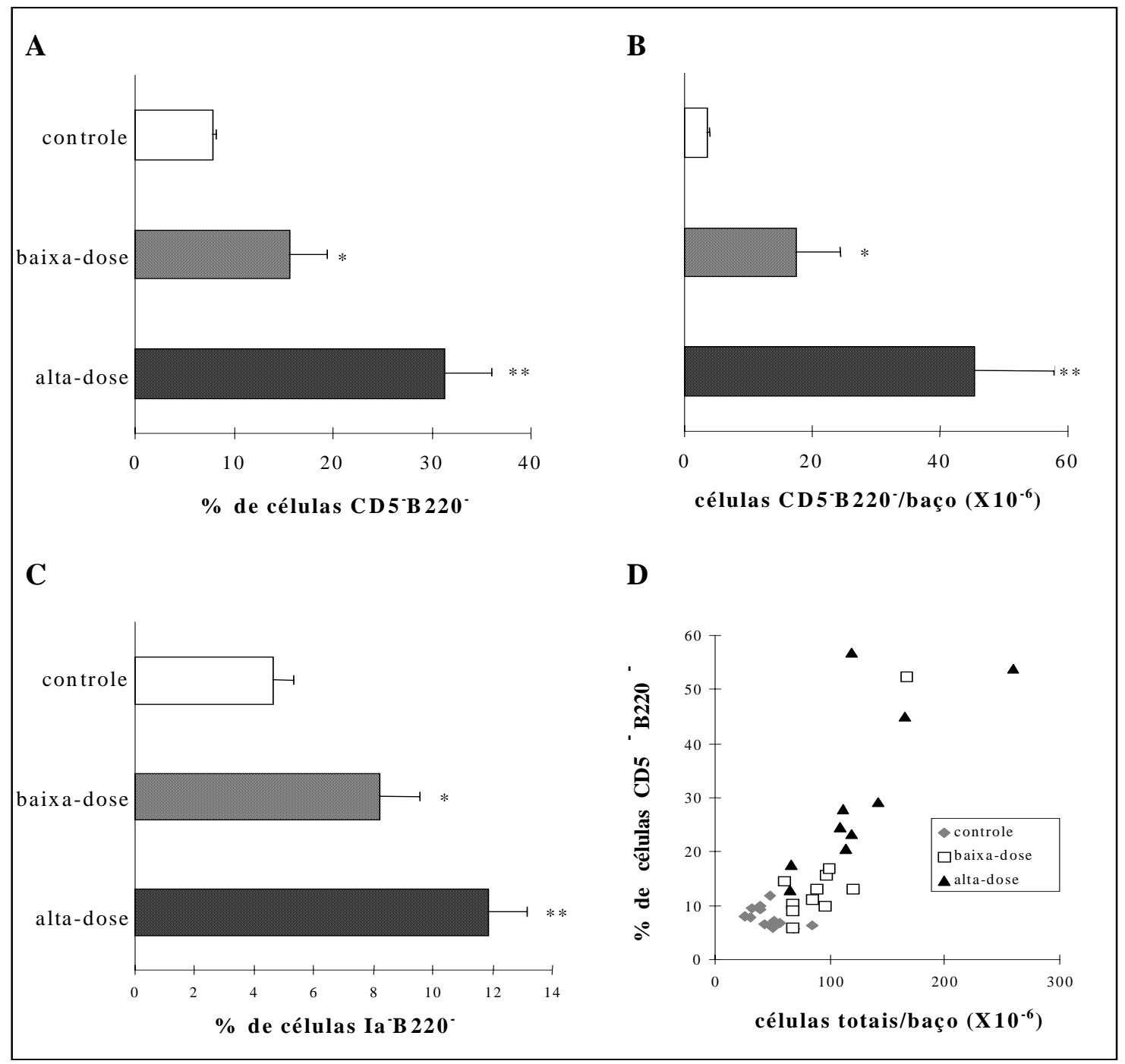

Figura 9- Análise das células $\mathrm{CD}^{\circ} \mathrm{B} 220^{-}$do baço de camundongos infectados via intraperitoneal com $10^{3}$ (baixa dose) ou $10^{5}$ (alta dose) formas tripomastigotas da cepa Y de T. cruzi. No 6ํำ dia de infecção, os animais de ambos os grupos e os do grupo controle foram tratados com uma dose única de $1 \mathrm{~g} / \mathrm{Kg}$ de peso corporal de Benzonidazol, via intragástrica. Um ano depois da infecção, suspensão de células do baço foram analisadas por citometria de fluxo (FACS) para determinar a freqüência de células $\mathrm{CD}^{-}{ }^{-B 220^{-}}$(A) e de células la ${ }^{+} B 220^{-}$(C). O total de células CD5'B220- por baço foi calculado considerando o número total de células do baço (B). Correlação entre as freqüências de células CD5'B220` e o número total de células do baço (D). Cada barra representa a média \pm EP dos valores individuais de 10-11 camundongos. As médias de cada grupo foram comparadas através do teste $t$ de Student. * $p<0,05$ entre os grupos crônicos e controle; ** $p<0.05$ entre o grupos de alta dose e os outros grupos. 
receptores para Fc e altos níveis da integrina e receptor para o complemento Mac-1 (resultados preliminares). Estes resultados indicam, possivelmente, que tratam-se de macrófagos. A freqüência de células $\mathrm{B}^{2} 20^{-}$ CD5 ${ }^{-}$no baço dos camundongos infectados, mas não a dos controles, tem uma forte correlação com o total de células esplênicas nestes animais (índices de correlação de $-0.480,+0.849$ e +0.733 para os controles, grupo infectado com baixa dose e grupo infectado com alta dose, respectivamente) (Fig. 9D). O número total de células $\mathrm{B}^{2} 2 \mathrm{C}^{\circ} \mathrm{CD}^{-}$no baço dos animais infectados com alta dose, foi 2.7 vezes maior que o dos animais infectados com baixa dose e 13 vezes maior que o dos controles (Fig. 9B).

Voltando à análise das populações de linfócitos, observou-se que os animais infectados tiveram um aumento na freqüência dos blastos nas três populações linfocitárias, principalmente os do grupo infectado com alta dose (Fig. 8D, E e F). Entretanto, em relação à freqüência dos blastos $\mathrm{CD}^{+}$, as diferenças entre os grupos infectados não foram significativas. Porém, quando foi considerado o número total de blastos linfocitários no baço, observamos um acentuado e significante aumento nas três populações linfocitárias, principalmente no grupo infectado com maior dose (Fig. 8G, H e I - barras sombreadas).

\subsection{Análise da expressão de CD45RB pelas células CD4 ${ }^{+}$}

Utilizamos o anticorpo monoclonal clone 16a para analisar a expressão da molécula CD45RB nas células $C D 4^{+}$. Esta isoforma da tirosina fosfatase CD45 divide a população $\mathrm{CD}^{+}$em duas sub-populações, CD45RB ${ }^{\text {high }}$ que inclui as células "naive" e possivelmente as células efetoras do tipo Th1, e a $\mathrm{CD}_{45 R B}{ }^{\text {low }}$ que inclue as células experimentadas e de memória e, provavelmente, as células efetoras do tipo Th2 (BOTTOMLY et al., 1989; LEE et al., 1990) (Fig. 10).

Nossos resultados indicam que nos animais infectados com alta dose, as células $\mathrm{CD}^{+}$exibem uma mudança em direção ao fenótipo CD45RB ${ }^{\text {Low }}$. Assim, a freqüência de células CD45RB ${ }^{\text {Low }}$ na população $C D 4^{+}$muda de $52.1 \%$ nos 


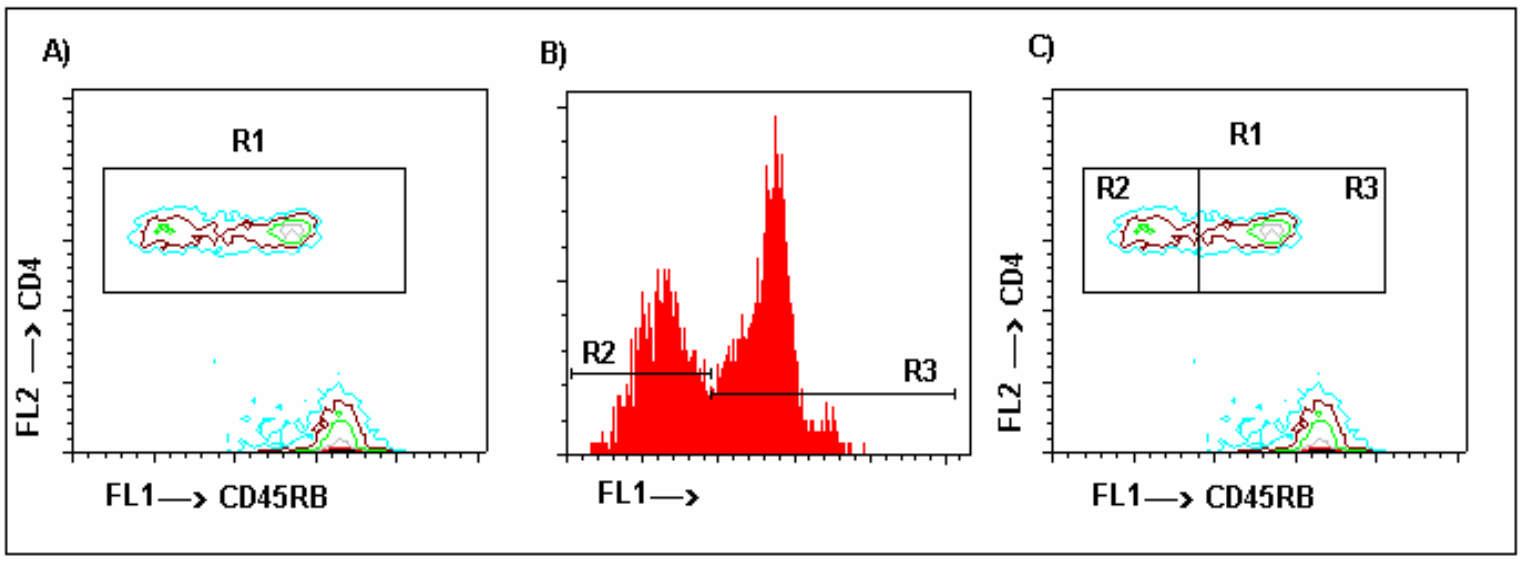

Figura 10- Esquema ilustrativo do procedimento utilizado para divisão da população de linfócitos $\mathrm{CD}^{+}$nas sub-populações com alta (CD45RB ${ }^{\text {high }}$ ) e baixa (CD45RB ${ }^{\text {low }}$ ) expressão do produto do exon B da molécula de CD45. Painel A mostra a seleção das células $C D 4^{+}$na região $\mathrm{R} 1$, que estão representadas na painel $\mathrm{B}$ em relação a expressão de CD45RB (FL1). Posteriormente foram divididas duas populações, uma com baixa expressão (R2-CD45RB ${ }^{\text {low }}$ ) e outra com alta expressão (R3-CD45RB ${ }^{\text {high }}$ ) que estão representadas na forma de contour plot na painel $\mathbf{C}$. 
animais controles para 53,8\% e 59,9\% nos grupos infectados com baixa e alta dose, respectivamente (Fig. 11A).

O número total de células $\mathrm{CD}^{+} \mathrm{CD} 45 \mathrm{RB} \mathrm{B}^{\text {High }}$ e $\mathrm{CD} 4^{+} \mathrm{CD} 45 \mathrm{RB} \mathrm{B}^{\text {Low }}$ aumentou em ambos os grupos infectados em relação ao dos controles (Fig. 11B). A sub-população $C D 4^{+} C D 45 R B^{\text {Low }}$ foi significantemente expandida no grupo infectado com alto inóculo. Entretanto, nenhuma diferença foi observada entre os grupos experimentais em relação ao número de células por baço da sub-população CD4 ${ }^{+}$CD45RB ${ }^{\text {High }}$.

A análise da freqüência de células blásticas $\mathrm{CD}^{+}$dos fenótipos CD45RB ${ }^{\text {High }}$ e $C D 45 R B^{\text {Low }}$ mostrou que nos animais crônicos existe um aumento no número de blastos de ambos os fenótipos, principalmente nos animais infectados com alta dose (Fig. 11C). Quando o número total de blastos por baço foi analisado, estas diferenças foram ainda mais pronunciadas (Fig. 11D). É interessante notar que, a razão entre o número total de células blásticas $\mathrm{CD}^{+} \mathrm{CD} 45 \mathrm{RB} \mathrm{B}^{\text {Low }}$ e $\mathrm{o}$ número total de células blásticas $\mathrm{CD}^{+} \mathrm{CD} 45 \mathrm{RB}^{\text {High }}$ no baço não muda nos camundongos cronicamente infectados pelo $T$. cruzi. Resultados similares aos obtidos com o anticorpo monoclonal 16a foram obtidos com o anticorpo monoclonal 23G2, que detecta diferentes epítopos da molécula de CD45RB (dados não mostrados).

\subsection{Análise das células produtoras de imunoglobulinas}

Os resultados dos ensaios de ELISASPOT mostram que os animais crônicos, especialmente aqueles do grupo infectado com alta dose, possuem no baço um significante aumento do número de células produtoras de imunoglobulinas, quando comparados ao dos controles (Fig. 12). Em ambos os grupos infectados estas células secretavam principalmente IgG, com predomínio marcante do isotipo lgG2a.

Os animais infectados com alta dose mostraram maior número total de células produtoras de IgM, IgG1 e IgG2b em relação ao grupo infectado com baixa dose. No entanto, não fram detectadas diferenças estatisticamente significantes em relação ao número total de células produtoras de lgG3 e lgG2a 


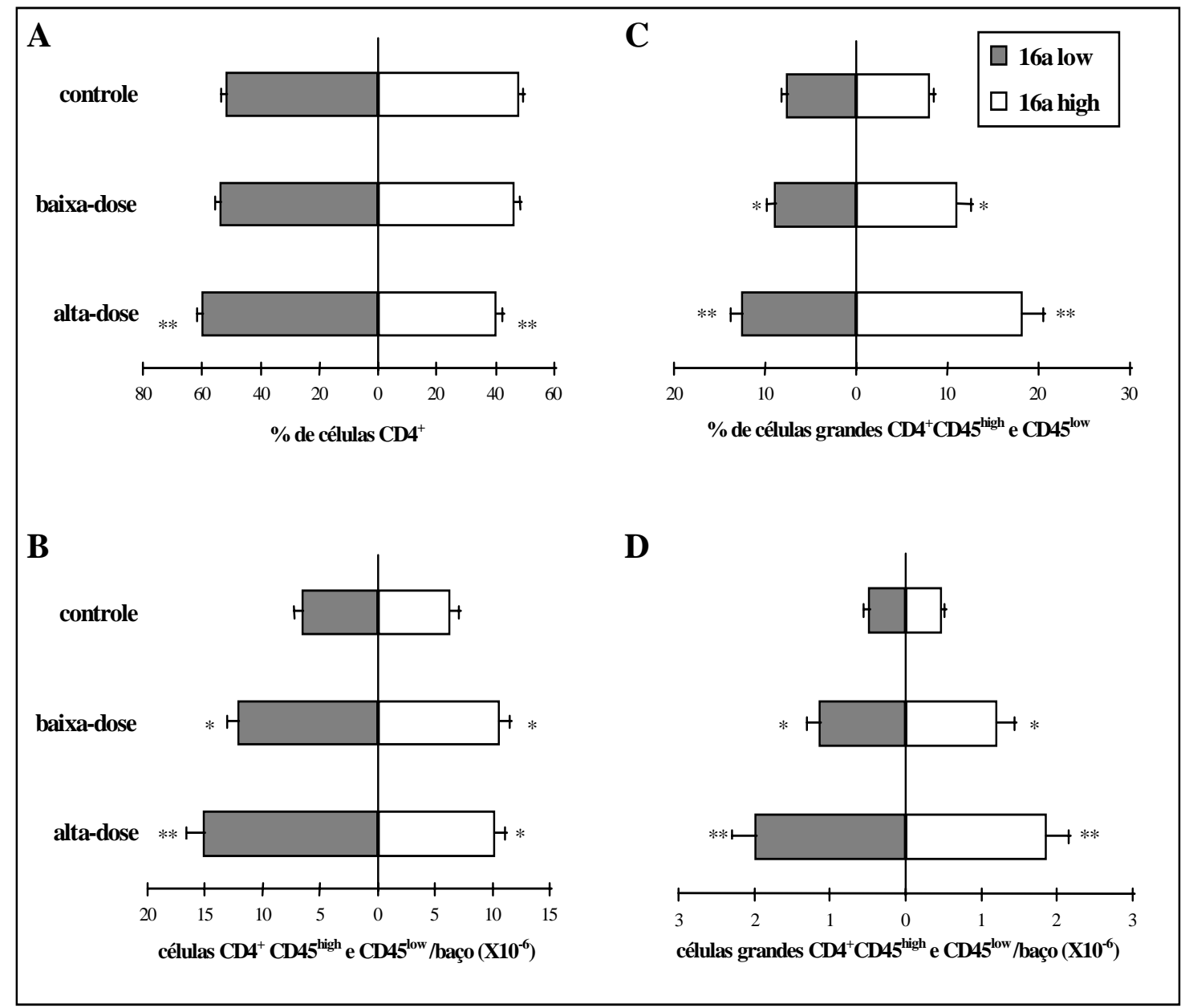

Figura 11- Expressão de CD45RB pelas células $C D 4^{+}$do baço de camundongos infectados via intraperitoneal com $10^{3}$ (baixa dose) ou $10^{5}$ (alta dose) formas tripomastigotas da cepa $Y$ de $T$. cruzi. No 6을 dia de infecção, os animais de ambos os grupos, e os do grupo controle foram tratados com uma dose única de $1 \mathrm{~g} / \mathrm{Kg}$ de peso corporal de Benzonidazol, via intragástrica. Um ano depois da infecção, suspensão de células do baço foram analisadas por citometria de fluxo (FACS) para determinar nas células $\mathrm{CD}^{+}$a expressão de CD45RB (anticorpo monoclonal clone 16a). Freqüência das células $C D 4^{+} C D 45 R B^{\text {low }}$ e $C D 4^{+} C D 45 R B^{\text {high }}$ (A). Número total de células $C D 4^{+} C D 45 R B^{\text {low }}$ e $C D 4^{+} C D 45 R B^{\text {high }}$ por baço, calculado a partir do número total de esplenócitos (B). Freqüência de células grandes nas sub-populações $C D 4^{+} C D 45 R B^{\text {low }}$ e $C D 4^{+} C D 45 R B^{\text {high }}$, calculadas através da análise de FSC (Forward scatter) (C). Número total de células grandes $C D 4^{+} C D 45 B^{\text {low }}$ e $C D 4^{+} C D 45 R B^{\text {high }}$ por baço (D). Cada barra representa a média \pm EP dos valores individuais de 10-11 camundongos. As médias de cada grupo foram comparadas através do teste $t$ de Student. * $p<0,05$ entre os grupos crônicos e controle; ** $p<0,05$ entre o grupo de alta dose e os outros dois grupos. 


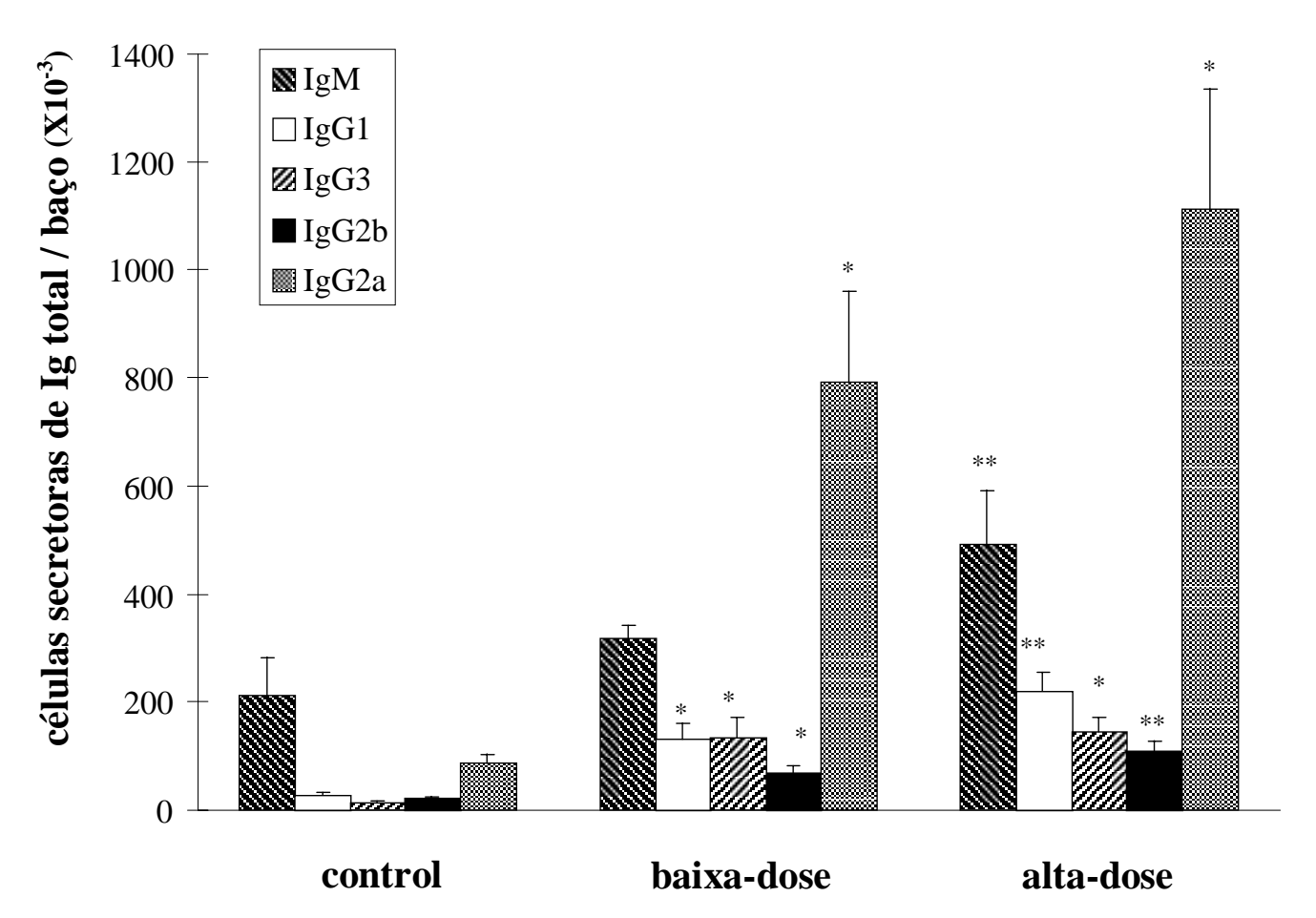

Figura 12- Análise das células produtoras de imunoglobulinas (Igs) no baço de camundongos infectados via intraperitoneal com $10^{3}$ (baixa dose) ou $10^{5}$ (alta dose) formas tripomastigotas da cepa $Y$ de $T$. cruzi. No $6^{\circ}$ dia de infecção, os animais de ambos os grupos e os do grupo controle foram tratados com uma dose única de $1 \mathrm{~g} / \mathrm{Kg}$ de peso corporal de Benzonidazol, via intragástrica. Um ano depois da infecção, células esplênicas dos grupos controle e infectados foram analisadas por ELISASPOT para determinar o número total por baço de células produtoras de Igs dos diferentes isotipos. Cada barra representa a média \pm EP dos valores individuais de 10-11 camundongos. As médias de cada grupo foram comparadas através do teste $t$ de Student. * $\mathrm{p}<0,05$ entre os grupos crônicos e controle; ** $\mathrm{p}<0,05$ entre o grupo de alta dose e os outros dois grupos. 
(isótipos dependentes de IFN- $\gamma$ ) entre esses dois grupos (Fig. 12). Mais ainda, quando comparados os grupos infectados com relação ao número de células produtoras de imunoglobulinas por $10^{6}$ esplenócitos verificou-se que o número de células produtoras de IgG1, mas não as de outros isótipos, foi significantemente mais elevado nos camundongos infectados com alta dose (Fig. 13).

\subsection{Análise de anticorpos séricos anti- T. cruzi}

A análise dos anticorpos anti-T. cruzi no soro de camundongos crônicos revelou níveis de IgM, IgG1, IgG3, IgG2b e IgG2a elevados em relação aos dos animais controle (Fig. 14). Corroborando com os resultados obtidos na análise das células produtoras de imunoglobulinas mostrados anteriormente, verifica-se que IgG2a é também o isotipo predominante no soro dos animais infectados. Quando comparamos os grupos infectados, observamos que os animais infectados com alta dose possuíam no soro níveis de IgM menores e níveis de IgG1 e IgG2a mais elevados que os animais infectados com baixa dose. Entretanto, quando comparamos os animais infectados com alta e baixa dose em relação aos níveis de IgG2b e IgG3 anti- $T$. cruzi no soro, não observamos diferenças significantes.

A determinação das concentrações de IgG1 e IgG2a específicas ao parasita no soro dos animais crônicos, mostrou que os animais infectados com alta dose tinham 1,23 vezes mais IgG1 e 2,34 vezes mais IgG2a do que os animais infectados com baixa dose (Fig 15). É importante destacar que a concentração de IgG2a específica no soro era de 40X e 38X superior à de IgG1, nos grupos infectados com alta e baixa dose respectivamente.

\subsection{Análise de citocinas secretadas por células esplênicas}

A produção de citocinas por células do baço dos animais crônicos foi avaliada por ELISA de captura nos sobrenadantes de culturas estimuladas com 


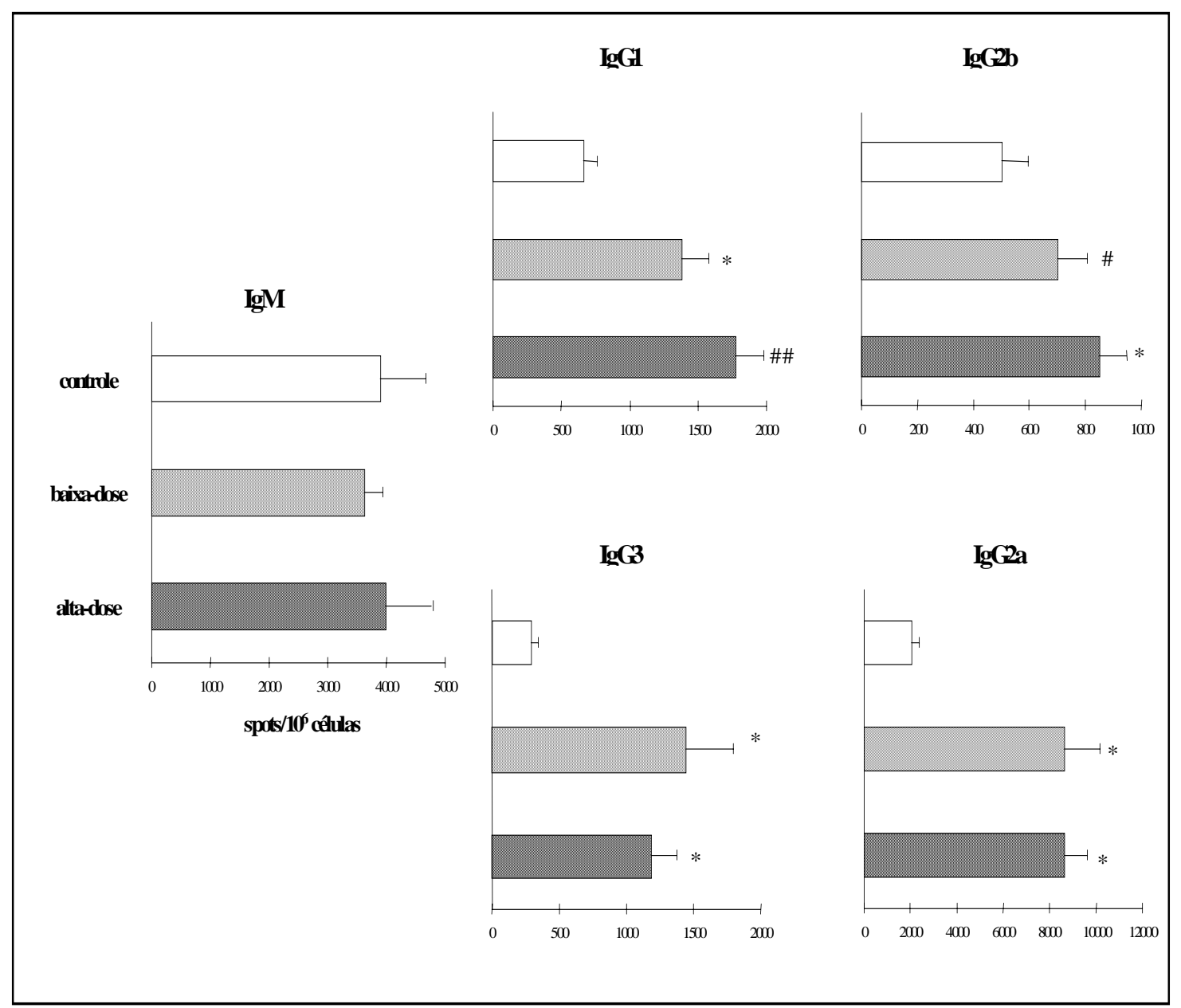

Figura 13- Análise das células produtoras de imunoglobulinas (Igs) no baço de camundongos infectados via intraperitonial com $10^{3}$ (baixa dose) ou $10^{5}$ (alta dose) formas tripomastigotas da cepa $Y$ de $T$. cruzi. No $6^{\circ}$ dia de infecção, os animais de ambos os grupos e os do grupo controle foram tratados com uma dose única de $1 \mathrm{~g} / \mathrm{Kg}$ de peso corporal de Benzonidazol, via intragástrica. Um ano depois da infecção células do baço dos grupos controle e infectados foram analisadas por ELISASPOT para determinar o número de células produtoras de Igs dos diferentes isotipos por $10^{6}$ esplenócitos. Cada barra representa a média \pm EP dos valores individuais de 10-11 camundongos. As médias de cada grupo foram comparadas através do teste $t$ de Student. * $p<0,05$ entre os grupos crônicos e controle; \# $p<0,1$ entre os grupos crônicos e controle; \#\# $p<0,1$ entre o grupo de alta dose e os outros dois grupos. 


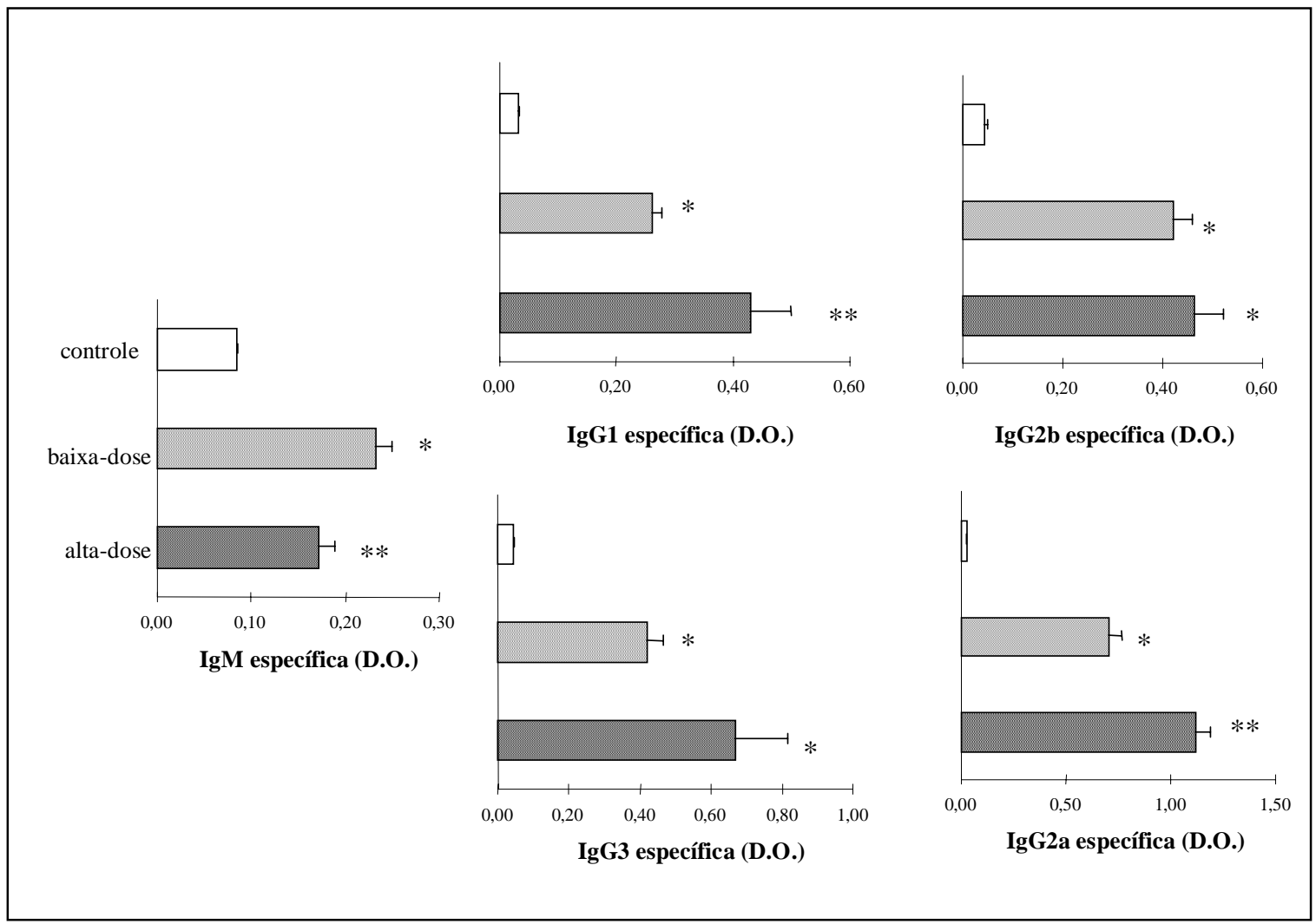

Figura 14- Análise de anticorpos específicos para o parasitas das diferentes classes e sub-classes no soro de camundongos de fase crônica infectados via intraperitoneal com $10^{3}$ (baixa dose) ou $10^{5}$ (alta dose) formas tripomastigotas da cepa $Y$ de $T$. cruzi. No $6^{0}$ dia de infecção, os animais de ambos os grupos e do grupo controle foram tratados com uma dose única de $1 \mathrm{~g} / \mathrm{Kg}$ de peso corporal de Benzonidazol, via intragástrica. Um ano depois da infecção, os animais foram sangrados e seus soros analisados por ELISA para determinação dos níveis de anticorpos específicos para o parasitas das subclasses IgM, IgG1, IgG2b, IgG3 e IgG2a. Os níveis de imunoglobulinas estão expressos em D.O. e correspondem a amostras de soro diluídas 1/100 para IgG3 e IgG2b, 1/800 para IgM e IgG1, e 1/3200 para IgG2a. Cada barra representa a média \pm EP dos valores individuais de 10-11 camundongos. As médias de cada grupo foram comparadas através do teste $t$ de Student. * $p<0,05$ entre os grupos crônicos e controle; ${ }^{*} p<0,05$ entre $o$ grupo de alta dose e os outros dois grupos. 


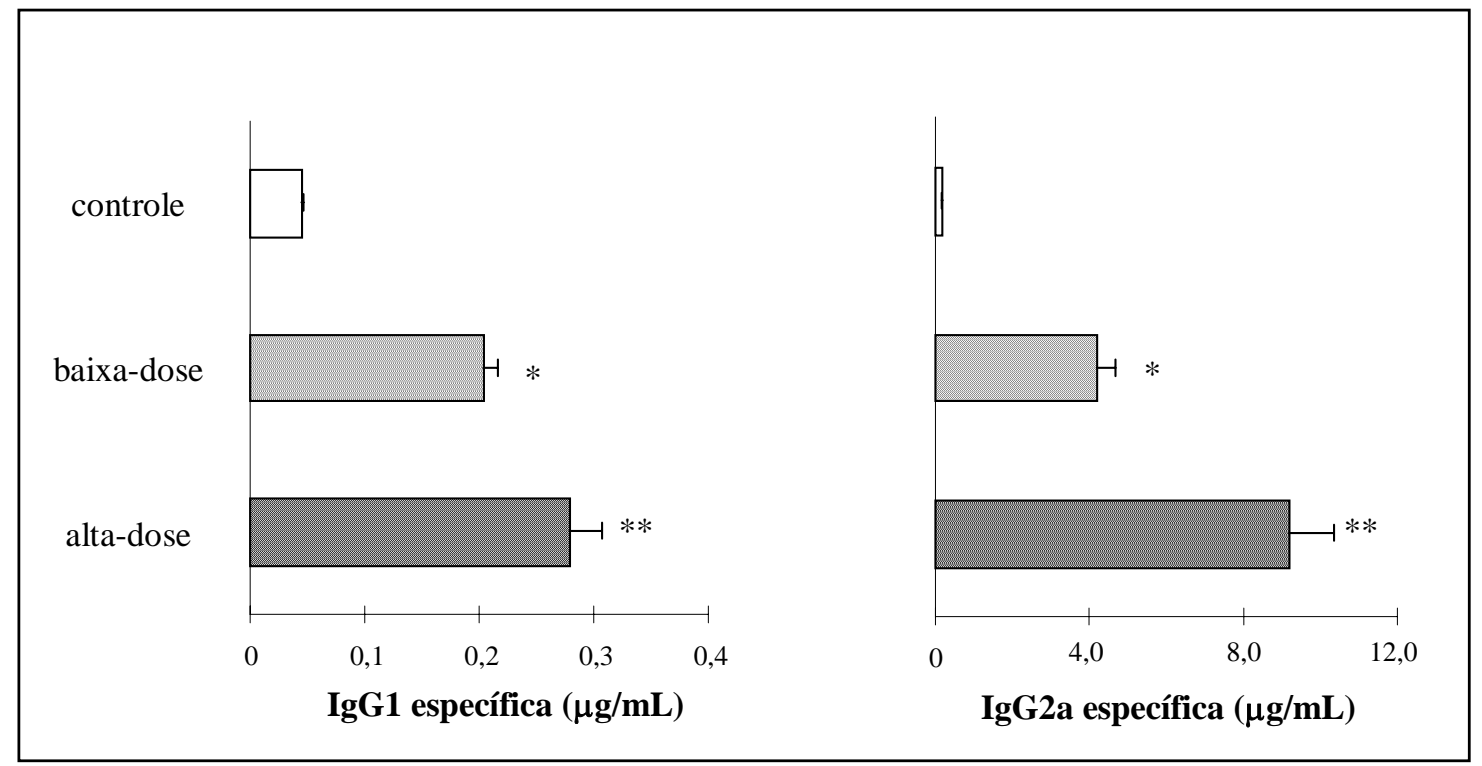

Figura 15- Quantificação de anticorpos específicos para o parasitas presentes no soro de fase crônica de camundongos infectados via intraperitoneal com $10^{3}$ (baixa dose) ou $10^{5}$ (alta dose) formas tripomastigotas da cepa $Y$ de $T$. cruzi. No $6^{\circ}$ dia de infecção, os animais de ambos os grupos e do grupo controle foram tratados com uma dose única de $1 \mathrm{~g} / \mathrm{Kg}$ de peso corporal de Benzonidazol, via intragástrica. Um ano depois da infecção, os animais foram sangrados e seus soros analisados por ELISA para quantificação de anticorpos parasita-específicos das subclasses IgG1 e IgG2a. As concentrações $(\mu \mathrm{g} / \mathrm{ml})$ dos anticorpos específicos foram calculadas a partir de uma curva padrão, como está descrito nos materiais e métodos. Cada barra representa a média \pm PE dos valores individuais de 1011 camundongos. As médias de cada grupo foram comparadas através do teste $t$ de Student. * $p<0,05$ entre os grupos crônicos e controle; ${ }^{*}{ }^{*}<<0,05$ entre o grupo de alta dose e os outros dois grupos. 
Concanavalina A. Para cada citocina, os resultados apresentados na figura 16 correspondem ao pico de produção entre 24-72h. Animais infectados com alta dose secretaram uma maior quantidade de IFN- $\gamma$ e IL-4 quando comparados com animais infectados com baixa dose (Fig. 16A e B). A análise de correlação entre a produção de IL-4 e IFN- $\gamma$ de cada animal, revelou que nos animais crônicos não existe uma correlação negativa entre a produção destas citocinas, uma vez que os índices de correlação eram de -0,154, +0,496 e $+0,391$, para os animais controle, baixa e alta dose, respectivamente. Mais ainda, quando os animais crônicos foram divididos em grupos com parasitemia positiva e parasitemia negativa, foi observada uma correlação direta (positiva) entre a produção de IL-4 e IFN $\gamma$ nos animais com parasitemia positiva (índice de correlação +0.80) (Fig. 16E). Para os animais com parasitemia negativa e controles os índices de correlação foram próximos de zero. A produção de IL-2 foi significantemente menor nos grupos infectados, quando comparada à dos controles (Fig. 16C). A produção de IL-10 foi mais elevada nos animais do grupo infectado com alta dose, mas devido à alta variabilidade, as diferenças com relação aos demais grupos não foram significantes (Fig. 16D). No entanto, quando os animais crônicos foram divididos em grupos com parasitemia positiva e negativa observamos que os animais com parasitemias positivas secretavam níveis de IL-10 mais elevados do que os animais com parasitemias negativas (Fig. 16F). 


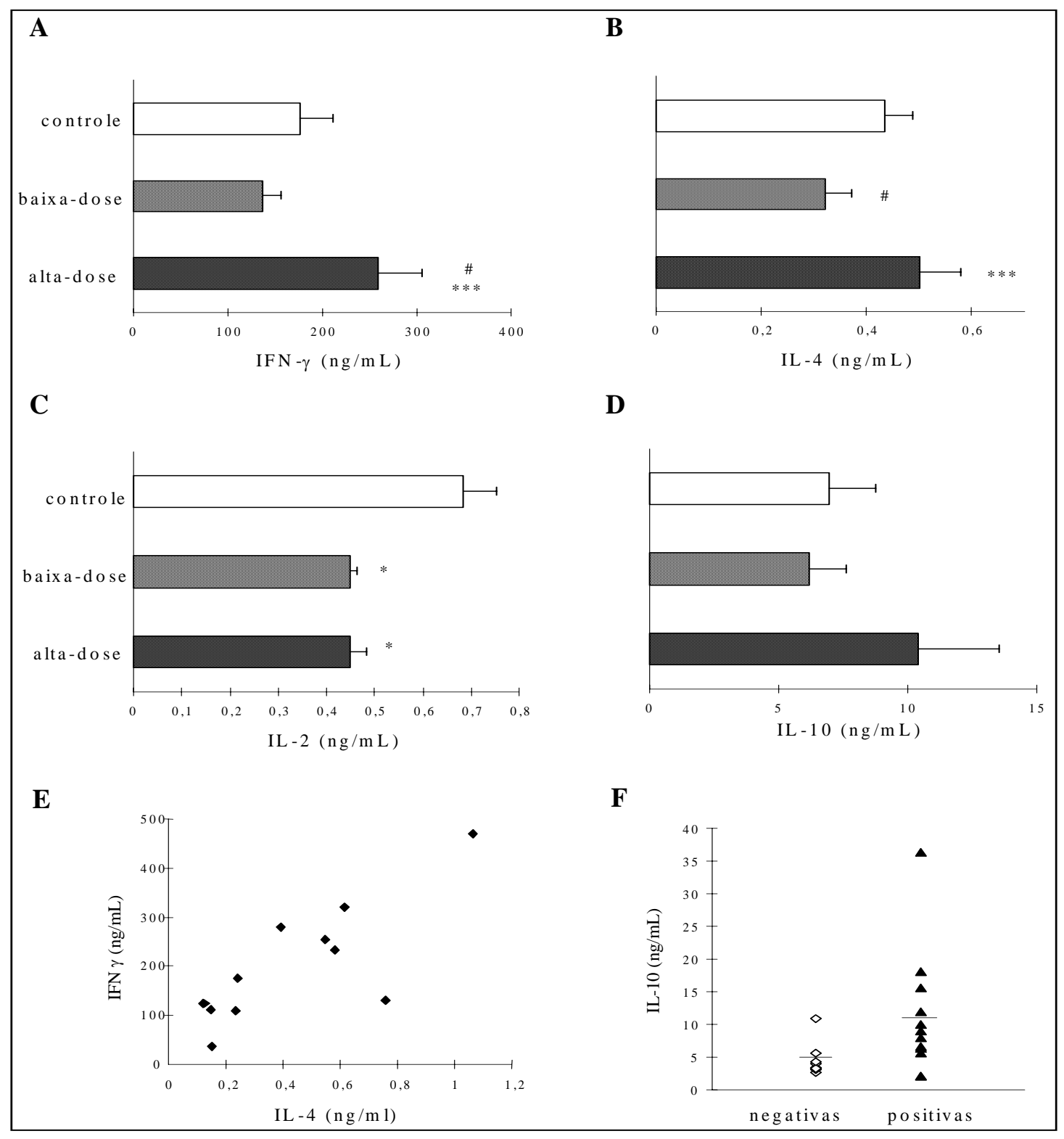

Figura 16- Produção de citocinas durante a fase crônica pelas células do baço de camundongos infectados via intraperitoneal com $10^{3}$ (baixa dose) ou $10^{5}$ (alta dose) formas tripomastigotas da cepa Y de T. cruzi. No $6^{\circ}$ dia de infecção, os animais de ambos os grupos e do grupo controle foram tratados com uma dose única de $1 \mathrm{~g} / \mathrm{Kg}$ de peso corporal de Benzonidazol, via intragástrica. Um ano depois da infecção, culturas de células do baço foram incubadas com ConA e seus sobrenadantes (24h, 48h e $72 \mathrm{~h}$ ) testados por ELISA de captura. Os dados apresentados correspondem ao pico de produção de cada citocina, IFN $\gamma$ (A), IL-4 (B), IL2 (C) e IL-10 (D). Correlação entre a produção individual de IFN $\gamma$ e IL-4 em animais crônicos com parasitemia positiva (E). Produção de IL-10 em animais com parasitemia positiva e negativa (F). Cada barra em A-D representa a média \pm EP dos valores individuais de 10-11 camundongos. As médias de cada grupo foram comparadas através do teste $t$ de Student. * $\mathrm{p}<0,05$ comparado com o grupo controle; \# $\mathrm{p}<0,1$ comparado com o grupo controle; ${ }^{\star \star \star} p<0,05$ comparado com o grupo de baixa dose. 
5. DISCUSSÃO 
Nossos resultados indicam que o nível de parasitemia na fase aguda da doença de Chagas experimental tem uma correlação direta com os níveis da parasitemia, intensidade de patologia e ativação do sistema imune na fase crônica. Desta maneira, os ensaios de transferência com sangue de animal crônico mostraram que os camundongos infectados com alta carga parasitária possuíam, após um ano de infecção, níveis de parasitemia subpatente superiores aos dos animais que receberam baixa carga. A maior parasitemia no grupo de alta dose poderia ser resultado ou de uma maior entrada de parasitas no sangue, ou de um controle menos eficiente sobre os parasitas que por ventura atingissem a circulação. A última possibilidade é, entretanto, pouco provável, uma vez que o sistema imune dos animais infectados com alta dose de parasitas é mais ativo, apresentando mais células (Ex: $\operatorname{LTCD8}^{+}$e macrófagos) e moléculas efetoras envolvidas no controle da parasitemia (Ex: IFN- $\gamma$ e IgG2a) do que o grupo infectado com baixa dose. Por esta razão, as parasitemias exibidas na fase crônica pelos grupos de alta e baixa carga refletem, provavelmente, a saída de parasitas dos tecidos para os espaços extracelulares e para o sangue, sendo portanto, indicativas do nível de parasitismo tissular. Se, um ano após a infecção, as parasitemias ainda permanecem diferentes nos grupos crônicos, pode-se imaginar que os mecanismos efetores do sistema imune não são suficientemente eficientes no controle do parasitismo tissular.

Apesar das lesões no coração e no músculo esquelético não serem muito intensas, os infiltrados inflamatórios foram mais evidentes nos animais do grupo infectado com alta dose. Estes dados sugerem que a presença de altos níveis de parasita na fase aguda determina a persistência de um maior número de parasitas e o desenvolvimento de uma patologia mais intensa na fase crônica da doença. Desta forma, o controle da carga parasitária durante a fase aguda, que depende do "background" genético do parasita (POSTAM et al., 1987) e do hospedeiro (LLOP et al., 1988), está diretamente relacionado com a patologia na fase crônica da doença. Estes achados têm importantes implicações para a prevenção da patologia na Doença de Chagas, reforçando a necessidade de quimioterapia na fase inicial da infecção. O aumento das 
reações inflamatórias nos tecidos dos animais do grupo infectado com alta dose, também reforça a idéia de que estes animais têm índices mais elevados de parasitismo tissular. Embora nós não tenhamos detectado ninhos de parasitas no coração e no músculo esquelético, esta idéia é indiretamente apoiada por dados mostrados de pacientes chagásicos crônicos, onde observou-se uma correlação positiva entre miocardite e o grau de parasitismo cardíaco (HIGUCHI et al., 1993; JONES et al., 1993). Corroborando com estes resultados, VAGO et al. (1996) mostraram através de PCR, a presença de DNA do parasita no esôfago, unicamente naqueles pacientes chagásicos que apresentavam um quadro clínico de patologia digestiva. Além disso, o relato da existência de uma menor incidência de patologia após quimioterapia na fase crônica, reforça ainda mais a hipótese de uma correlação entre parasitismo e patologia (SEGURA et al., 1994; VIOTTI et al., 1994). Estes resultados não descartam o envolvimento da autoimunidade na cardiopatia chagásica crônica. Neste caso, a intensidade da reação autoimune dependeria também da carga parasitária. Entretanto, a existência de uma correlação entre carga parasitária na fase aguda e severeridade da lesão na fase crônica apóiam a hipótese do direto envolvimento do T. cruzi na patologia da doença de Chagas crônica.

O nível de parasitismo na fase aguda se correlaciona, na fase crônica, com a intensidade de ativação do sistema imune. De acordo com vários parâmetros imunológicos, as células do baço dos camundongos infectados com alta dose de parasitas estão mais ativadas do que aquelas provenientes dos camundongos infectados com baixo inóculo. Desta maneira, os animais infectados com alta dose de $T$. cruzi apresentavam em relação aos infectados com baixa dose:

i) acentuado aumento no número de esplenócitos, com preferencial expansão das populações celulares $\mathrm{CD}^{+}$e B220 CD5', muitas das quais apresentando o fenótipo de macrófagos.

ii) altas freqüências de células blásticas das sub-populações linfocitárias $\mathrm{B}^{2} 20^{+}, \mathrm{CD}^{+}$e $\mathrm{CD} 8^{+}$.

iii) uma mudança das células $\mathrm{CD}^{+}$em direção ao fenótipo CD45RB ${ }^{\text {low }}$, sugerindo um aumento nas células T experimentadas e/ou de memória.

iv) aumento nas freqüências de células blásticas $C D 4^{+} C D 45 R B^{\text {low }} \mathrm{e}$ $\mathrm{CD}^{+}$CD45RB ${ }^{\text {high }}$. 
v) aumento no número total de células secretoras de imunoglobulinas, com predominância da secreção de anticorpos do isótipo IgG2a.

vi) produção mais elevada de IFN- $\gamma$ e IL-4.

Além disto, os animais infectados com alta dose de parasitas apresentaram baixos níveis séricos de anticorpos específicos para o parasita da classe IgM e um aumento nas quantidades de IgG2a e IgG1. A produção de IL-2 foi reduzida em ambos os grupos infectados, confirmando o estado de supressão da produção desta linfocina observada in vitro e in vivo, tanto na fase aguda, quanto na fase crônica (HARELL-BELLAN et al., 1983; CUROTTOLAFAILLE et al., 1990; ZHANG \& TARLETON, 1996b).

Um dos nossos resultados mais interessantes foi o acúmulo de células B220 ${ }^{\circ} \mathrm{CD}^{-}$no baço dos animais infectados, notavelmente no grupo infectado com alta dose. Muitas destas células pareciam ser macrófagos, uma vez que eram grandes, tinham granulosidade pouco intensa e expressavam la, FcR e Mac-1 (dados não mostrados). Os macrófagos são essenciais para a retirada do T. cruzi, tanto do sangue, quanto do tecido, atuando junto com os anticorpos opsonizantes IgG2a. Além disso, são cruciais para a destruição intracelular dos parasitas, um processo que para os parasitas das cepas reticulotrópicas é criticamente dependente da ativação por citocinas como IFN- $\gamma$, TNF- $\alpha$ e GMCSF (MUNÕZ-FERNANDEZ \& FRESNO, 1992; OLIVARES-FONTT et al., 1996) e que é submetido à regulação negativa pela IL-10 e pelo TGF- $\beta$ (GAZZINNELLI et al., 1992; SILVA et al., 1991). Neste aspecto, é importante destacar que, em nossos experimentos, a alta produção de IL-10, citocina secretada por macrófagos, linfócitos Th2 e outras células (MOSMANN et al., 1991; MOSMANN \& MOORE, 1991), foi restrita a animais com parasitemia positiva, sendo muito baixa em animais crônicos com parasitemia negativa. A IL-10 tem sido indicada como uma importante citocina reguladora das respostas imunes danosas ao hospedeiro (KUHN et al., 1993). Desta forma, sua presença no baço do camundongo crônico poderia estar regulando os efeitos danosos da hiperativação macrofágica. Entretanto, devido a sua capacidade inibitória sobre a atividade macrofágica, a secreção desta citocina reduziria o controle do hospedeiro sobre os parasitas circulantes (HUNTER et al., 1997; ABRAHAMSON \& COFFMAN, 1996). 
Dentre os linfócitos esplênicos, os $\mathrm{CD}^{+}$foram os mais expandidos nos animais infectados, preferencialmente no grupo de alta dose. Além disso, esta foi a única população linfocitária onde o número total de células no grupo infectado com alta dose foi significantemente superior em relação ao número mostrado pelo grupo de baixa dose. Linfócitos $\mathrm{CD}^{+}$são importantes células efetoras no controle da infecção por $T$. cruzi, uma vez que animais depletados de $\mathrm{CD}^{+}$apresentam um aumento da parasitemia na fase aguda (ROTTEMBERG et al., 1995; TARLETON et al., 1992). Enquanto existem discrepâncias em relação à importância desta população no controle do parasitismo cardíaco, seu papel parece importante no fígado (ROTTEMBERG et al., 1995; RUSSO et al., 1996) e baço (ROTTEMBERG et al., 1995). Nas nossas experiências temos observado um aumento importante dessa população nos animais cronicamente infectados, principalmente naqueles do grupo infectado com alta dose. A nossa hipótese é que o seu aumento no baço, um dos principais órgãos de retirada de parasitas da circulação, pode ter um significante papel na destruição de macrófagos infectados, não ativados ou desativados, permissivos ao crescimento do parasita. Desta maneira, o reconhecimento pelas células $\mathrm{CD}^{+}$de peptídeos do parasita nas moléculas de classe I dos macrófagos infectados poderia induzir a destruição destas células e/ou produção de IFN $\gamma$, o qual, novamente, promoveria no macrófago a destruição intracelular das formas amastigotas. As células $\mathrm{CD}^{+}$presentes no baço poderiam ser essenciais no controle de parasitas reticulotrópicos que podem proliferar facilmente em macrófagos, a menos que estes estejam ativados.

A análise das células esplênicas produtoras de imunoglobulinas e dos anticorpos séricos anti-T. cruzi mostrou que os animais cronicamente infectados com baixa ou alta dose apresentam uma produção preferencial de anticorpos IgG2a. Uma vez que a mudança para este isotipo depende de IFN- $\gamma$, o predomínio de anticorpos IgG2a indica que o padrão de resposta Th1 é dominante na fase crônica da infecção pelo T. cruzi. Quando comparados entre si os grupos infectados, poucas diferenças em termos de distribuição de isótipos foram observadas. Apesar do predomínio Th1, entretanto, nossos dados mostram que os animais crônicos apresentam também células Th2 
ativadas. Interessantemente, de maneira similar à resposta Th1, a ativação das células Th2 também foi mais intensa em animais infectados com alta dose de parasitas. Assim, estes animais mostraram em relação ao grupo infectado com baixa dose:

i) um número maior de células produtoras de imunoglobulinas do isotipo $\lg \mathrm{I} 1$.

ii) níveis séricos mais elevados de anticorpos lgG1 específicos para o parasita.

iii) um número maior de células esplênicas grandes com fenótipo CD4 ${ }^{+}$CD45RB ${ }^{\text {low }}$.

iiii) uma produção de IL-4 similar à dos animais controle, mas significantemente superior à do grupo infectado com baixo inóculo.

Interessantemente, a análise de correlação entre a produção individual de IL-4 e IFN- $\gamma$ revelou que os animais crônicos não podem ser separados em função da produção independente destas citocinas. Além disso, nos animais com parasitemia positiva observou-se uma correlação direta entre a produção de IL-4 e IFN $\gamma$, sugerindo que a produção de IL-4 acompanha a secreção de IFN $\gamma$. Estes resultados indicam que, nos animais crônicos, a sinalização para secreção de IL-4 também depende da carga parasitária. A produção desta citocina nestes animais pode ser o resultado da apresentação dos antígenos parasitários por APCs diferentes daquelas envolvidas na sinalização de perigo e/ou ser conseqüência de mecanismos de homeostase envolvidos no balanço Th1/Th2. Neste sentido, é interessante observarmos que a relação entre os números de células grandes com fenótipos $C D 4^{+} C D 45 R B^{\text {low }} \mathrm{e}$ CD4 ${ }^{+} C D 45 R B^{\text {high }}$, se mantém conservada tanto nos controles, quanto nos animais infectados com alta e baixa dose. Estes resultados sugerem que, o sistema imune dos animais cronicamente infectados tende ao equilíbrio, independentemente do nível de parasitas circulantes. A presença de células $\mathrm{CD}^{+} \mathrm{CD} 45 \mathrm{RB}{ }^{\text {high }}$ tem sido correlacionada com um comportamento autoagressivo, uma vez que a sua transferência para camundongos Scid determina caquexia, assim como infiltrados inflamatórios em diversos órgãos, sendo que este quadro pode ser revertido com a introdução de células CD4 ${ }^{+}$CD45RB ${ }^{\text {low }}$ (POWRIE \& MASON, 1990). 
Nossos resultados mostram que o nível de parasitemia na fase aguda da infecção pelo T.cruzi afeta diretamente, na fase crônica, a parasitemia, a patologia e a resposta imune. Este estudo abre uma importante perspectiva, no sentido de que a patologia crônica pode ser reduzida, utilizando-se para este fim protocolos terapêuticos que controlem os níveis de parasitemia na fase aguda da infecção. 
6. CONCLUSÕES 
O nível de parasitas (carga parasitária) na fase aguda da infecção pelo Trypanosoma cruzi se correlaciona com os níveis de parasitemia, patologia e ativação do sistema imune na fase crônica da infecção.

Desta maneira, em relação aos animais infectados com baixa carga parasitária, os animais infectados com alta carga apresentam na fase crônica:

- um maior nível de parasitemia residual.

- uma maior quantidade de lesões no coração e no músculo esquelético.

- um número superior de esplenócitos, com expansão preferencial das populações B220CD5 (possivelmente macrófagos) e linfócitos CD8 ${ }^{+}$.

- um número superior de blastos nas populações linfocitárias B220 $\mathrm{CD}^{+}$e $\mathrm{CD} 4^{+}$.

- uma mudança acentuada nas células $\mathrm{CD}^{+}$para 0 fenótipo $\mathrm{CD} 4^{+} \mathrm{CD} 45 \mathrm{RB}^{\mathrm{Low}}$, indicando um aumento das células efetoras e/ou de memória.

- freqüências mais elevadas de blastos $C D 4^{+} C D 45 R B^{\text {High }}$ e $\mathrm{CD}^{+}{ }^{+} \mathrm{CD} 45 \mathrm{RB}^{\mathrm{Low}}$.

- um número superior de células secretoras de imunoglobulinas.

- uma produção maior de IFN- $\gamma$ e de IL-4.

- níveis séricos de anticorpos específicos para o parasita inferiores para IgM e superiores para IgG2a e IgG1. 
7. REFERÊNCIAS BIBLIOGRÁFICAS 
De acordo com:

ASSOCIAÇÃO BRASILEIRA DE NORMAS TÉCNICAS. Referências Bibliográficas:

NBR 6023. Rio de Janeiro: ABNT, 1989.

NATIONAL LIBRARY OF MEDICINE. List of Journals Indexed in Index Medicus.

Bethesda: NLM, 1997.

ABBAS, A.K.; LITCHMAN, A.H.; POBER, J.S. Cellular and molecular immunology. 2 ed., New York, Saunders, 1994. p. 239-60.

ABRAHAMSOHN, I.A. \& COFFMAN, R.L. Trypanosoma cruzi: IL-10, TNF, IFNgamma, and IL-12 regulate innate and acquired immunity to infection. Exp. Parasitol., 84: 231-44, 1996.

ABRAHANSOHN, I.A. \& DIAS DA SILVA, W. Antibody dependent cell mediated cytotoxicity against Trypanosoma cruzi. Parasitology, 75: 317-23, 1977.

ABRAHANSOHN, I.A. Estudo morfológico da interação parasito hospedeiro no sítio de inoculação de formas tripomastigotas de Trypanosoma cruzi em camundongos normais e imunes. São Paulo, 1988. (Tese de Livre Docência - Instituto de Ciências Biomédicas da Univ. de São Paulo).

ALCÂNTARA, A. \& BRENER, Z. The in vivo interaction of Trypanosoma cruzi bloodstream forms and mouse peritoneal macrophages. Acta Trop., 35: 209-19, 1978.

ALIBERTI, J.C.; CARDOSO, M.A.; MARTINS, G.A; GAZINELLI, R.T.; VIEIRA, L.Q.; SILVA J.S. Interleukin-12 mediates resistance to Trypanosoma cruzi in mice and is produced by murine macrophages in response to live trypomastigotes. Infect. Immun., 64: 1961-67, 1996.

ALVAREZ, J.M.; OSHIMA, A.; MOZER, V.; GUIMARÃES, L.; MENEZES, H. Evolution of subpatent parasitaemia In Trypanosoma cruzi chronically 
infected mice with the help of a cyclophosphamide amplification transfer assay. Rev. Inst. Med. Trop. São Paulo, 33: 509-14, 1991.

ANDRADE, Z.A. \& ANDRADE, S.G. Patologia. In: Brener, Z.; Andrade, Z. (eds). Trypanosoma cruzi e doença de Chagas. Rio de Janeiro, Guanabara Koogan,1979. p.199.

ANSELMI, A. \& MOLEIRO, F. Pathogenic mechanisms in Chagas' cardiomyopathy. Ciba Found Symp., 20: 125, 1974.

ARAÚJO, F.G. Development of resistance to Trypanosoma cruzi in mice depends on a viable population of L3T4+ (CD4+) T lymphocytes. Infect. Immun., 57: 2246-48, 1989.

AVRAMEAS, S.; TERNYCK, T.; GUESDON, J.L. Coupling of enzymes to antibodies and antigens. Scand. J. Immunol., 8: 7-23, 1979.

BANCHEREAU, J.; DE PAOLI, P.; VALLE, A.; GARCIA, E.; ROUSSET. Longterm human $B$ cell lines dependent on interleukin-4 and antibody to CD 40. Science, 251: 70-72, 1991.

BAUER, H.; JUNG, T.; TSIKAS, D.; STICHTENOTH, D.O; FROLICH, J.C.; NEUMANN, C. Nitric oxide inhibits the secretion of T-helper 1- and Thelper 2-associated cytokines in activated human T cells. Immunology, 90: 205-11, 1997.

BERAH, M.; HORS, J.; DAUSSET, J. A study of HLA antigens in human organs. Transplantation, 9: 185-92, 1970.

BOTTOMLY, K.; LUQMAN, M.; GREENBAUM, L.; CARDING, S.; WEST, J.; PASQUALINI, T.; MURPHY, D.B. A monoclonal antibody to murine CD45R distinguishes CD4 $\mathrm{T}$ cell populations that produce different cytokines. Eur. J. Immunol., 19: 617-23, 1989.

BRENER, Z. \& ANDRADE, Z.A. Trypanosoma cruzi e Doença de Chagas. Rio de Janeiro: Guanabara Koogan, 1987. p. 6-10 
BRENER, Z. \& CHIARI, E. Variações morfológicas observadas em diferentes amostras de Trypanosoma cruzi. Rev. Inst. Med. Trop., 5: 220-4, 1963.

BRENER, Z. Immunity to Trypanosoma cruzi. Adv. Parasitol., 18: 247-92, 1980.

BRENER, Z. Therapeutic activity and criterion of cure on mice experimentally infected with Trypanosoma cruzi. Rev. Inst. Med. Trop., 4: 339, 1962.

BUDZKO, D.B.; PIZZIMENTI, M.C.; KIERSZENBAUM, F. Effects of complement depletion in experimental Chagas disease: immune lysis of virulent blood forms of Trypanosoma cruzi. Infect. Immun., 11: 86-91, 1975.

CAMARGO, M.E. \& TAKEDA, G.K.F. Diagnóstico de laboratório. In: Brener, Z. \& Andrade, Z. (eds) Trypanosoma cruzi e Doença de Chagas. Rio de Janeiro, Guanabara Koogan,1979. p.199.

CANÇADO, J.R. Tratamento específico. In: Cançado, J.R.; Chuster, M. (eds). Cardiopatia Chagásica. Minas Gerais: Fundação Carlos Chagas, 1985. p.325-55.

CARDILLO, F.; VOLTARELLI, J.C.; REED, S.G.; SILVA, J.S. Regulation of Trypanosoma cruzi in mice by gamma interferon and interleukin 10: role of NK cells. Infect. Immun., 64: 128-34, 1996.

CHAGAS, C. Nova tripanozomiaze humana. Estudos sobre a morfolojia e o ciclo evolutivo do Schizotrypanum cruzi, n. gen.n.sp., ajente etiolojico de nova entidade morbida do homem. Mem. Inst. Oswaldo Cruz, 1: 159218, 1909.

CHAN, S.H.; PERUSSIA, B.; GUPTA, J.W.; KOBAYASHI, M.; POSPISIL, M.; YUONG, H.A.; WOLF, S.F.; YUONG, D.; CLARK, S.C.; TRINCHIERI, G. Induction of interferon $\gamma$ production by natural killer cell stimulatory factor: characterisation of the responses cells and synergy with other induces. $\mathbf{J}$. Exp. Med., 173: 869-79, 1991. 
CHRIST, M.; McCARTNEY-FRANCIS, N.L.; KULKARNI, A.B.; WARD, J.M.; MIZEL, D.E.; MACKALL, C.L.; GRESS, R.E.; HINES, K.L.; TIAN, H.; KARLSSON, S.; WAHL, S.M. Immune dysregulation in TGF-b1-deficient mice. J. Immunol., 153: 1936-946, 1994.

COHN, Z. The activation of mononuclear phagocytes: fact, fancy and future. $\mathbf{J}$. Immunol., 12: 813-6, 1978.

COLEMAN, D.; CHODAKEWITZ, J.A.; BARTISS, A.H.; MELLORS, J.W. Granulocyte-macrophage colony-stimulating factor enhances selective effector functions of tissue-derived macrophages. Blood, 72: 573-78, 1988.

CUNHA-NETO, E.; DURANTI, M.; GRUBER, A., ZINGALES B., DE MESSIAS I., StOlF N., Belloti G., PATARROYO M E., PIllegi F., KAliL J. Autoimmunity in Chagas disease cardiopathy: biological relevance of a myosin-specific epitope cross-reactive to an immunodominant Trypanosoma cruzi antigen. Proc. Natl. Acad. Sci. USA, 92: 3541-545, 1995.

CUNNINGHAM, D.S. \& KUHN, R.E. Trypanosoma cruzi-induced suppression of the primary immune response in murine cell cultures to T-cell-dependent and -independent antigens. J. Parasitol., 66: 16-27, 1980.

CUROTTO DE LAFAILLE, M.A.; BARBOSA DE OLIVEIRA, L.C.; LIMA, G.C.; ABRAHANSOHN, I. Trypanosoma cruzi: maintenance of parasite-specific $T$ cell responses in lymph nodes during the acute phase of the infection. Exp. Parasitology, 70: 164-74, 1990.

CZERKINSKY, C.C.; NILSSON, L.A.; NYGREN, H.; OUTCHERLONY, O.; TARKOWSKI, A. A solid phase immunoenzymatic technique for the enumeration of specific antibody-secreting cells. J. Immunol. Methods., 65: 109-21, 1983.

D'ElIOS, M.M.; ROMAGNANI, P.; SCALETTI, C; ANNUNZIATO, F.; MANGHETTI, M.; MAVILIA, C.; PARRONCHI, P.; PUPILLI, C.; PIZZOLO, G.; MAGGI, E.; DEL PRETE, G.F.; ROMAGNANI, S. In vivo CD30 
expression in human diseases with predominant activation of Th2-like T cells. J. Leukocyte Biol., 61: 539-44, 1997.

DALMASSO, A.P. \& JARVINEN, J.A. Experimental Chagas' disease in complement-deficient mice and ginea pigs. Infect. Immun., 28: 434-90, 1980.

D'ANDREA, A; RENGARAJAU, M.; VALIENTE, N.M.; XIAOJING, M.; KUBIN, M.; TRINCHIERI, G. Interleukin 10 (IL-10) inhibits human lymphocyte interferon $\gamma$-production by suppressing natural killer cell stimulatory factor/IL-12 synthesis in accessory cells. J. Exp. Med., 178: 1041-48, 1993.

DE WAAL MALEFYT, R.; ABRAMS, J.; BENNET, B.; FIGDOR, C.; DE VRIES, J.E. IL-10 inhibits cytokine production by human monocytes. Autoregulatory role of IL-10 produced by monocytes. J. Exp. Med., 174: 1209-20, 1991.

DE WAAL MALEFYT, R.; YSSEL, H.; DE VRIES, J.E. Direct effects of IL-10 on subsets of human $\mathrm{CD}^{+} \mathrm{T}$ cell clones and resting $\mathrm{T}$ cells. Specific inhibition of IL-2 production and proliferation. J. Immunol., 150: 4754-65, 1993.

DENIS, M. Tumor necrosis factor and granulocyte macrophage colony stimulating factor stimulate human macrophages to restrict growth of virulent Mycobacterium avium and to kill avirulent $M$. avium. J. Leucocyte Biol., 49: 380-87, 1991.

D'IMPÉRIO LIMA, M.R.; ALVAREZ, J.M.; FURTADO, G.; KIPNIS, T.; COUTINHO, A.; MINOPRIO, P. Ig-Isotype patterns of primary and secondary $\mathrm{B}$ cell responses to Plasmodium chabaudi chabaudi correlate with IFN- $\gamma$ and IL-4 cytokine production and with CD45RB expression by CD4 $^{+}$spleen cells. Scand. J. Immunol., 43: 263-70, 1996.

D'IMPÉRIO LIMA, M.R.; EISEN, H.; MINOPRIO, P.; JOSKOWICZ, M.; COUTINHO, A. Persistence of polyclonal $B$ cell activation with undetectable parasitemia in late stages of experimental Chagas' disease.

J. Immunol., 137: 353-6, 1986. 
D'IMPÉRIO LIMA, M.R.; JOSKOWICZ, M.; COUTINHO, A.; KIPNIS, T.; EISEN, $\mathrm{H}$. Very large and isotypically atypical polyclonal plaque forming cell responses in mice infected with Trypanosoma cruzi. Eur. J. Immunol., 15: 201-3, 1985.

DOS SANTOS, R.R.; ROSSI, M.A.; LAUS, J.L.; SILVA, J.S.; SAVINO, W.; MENGEL, J. Anti-CD4 abrogates rejection and reestablishes long-term tolerance to syngeneic newborn hearts grafted in mice chronically infected with Trypanosoma cruzi. J. Exp. Med., 175: 29-39, 1992.

FERREIRA, M.U.; KIMURA, E.A.S.; SOUZA, J.M;.KATZIN A. M. The isotype composition and avidity of naturally acquired anti-Plasmodium falciparum antibodies: differential patterns in clinically immune africans and amazonian patients. Am. J. Trop. Med. Hyg, 55: 315-23, 1996.

FIORENTINO, D.F.; ZLOTNIK, A; MOSMANN, T.R.; HOWARD, M.; O'GARRA, A. IL-10 inhibits cytokine production by activated macrophage. J. Immunol., 147: 3815-22, 1991.

FISHER, H.G.; FROSCH, S.; RESKE-KUNZ, A. Granulocyte-macrophage colony-stimulating factor activates macrophages derived from bone marrow cultures to synthesis of MHC class II molecules and to augmented antigen presentation function. J. Immunol. 141: 3882-888, 1988.

FRASCH, A.C.C. \& REYES, M.B. Diagnosis of Chagas' disease using recombinant DNA technology. Parasitol. Today, 6: 137-39, 1990.

GASSON, J.C. Molecular physiology of granulocyte-macrophage colonystimulating factor. Blood, 77: 1131-145, 1991.

GAZZINELLI, R.; GALVAO, L.M.; DIAS, J.C.; GAZZINELLI, G.; BRENER, Z. Anti-laminin and specific antibodies in acute Chagas disease. Trans. R. Soc. Trop. Med. Hyg., 82: 574-6, 1988.

GAZZINELLI, R.T.; OSWALD, I.P.; HIENY, S.; JAMES, S.L.; SHER, A. The microbicial activity of interferon- $\gamma$ treated macrophages against Trypanosoma cruzi involves an L-arginine-dependent, nitrogen oxide- 
mediated mechanism inhabitable by IL-10 and transforming growth factorß. Eur. J. Immunol., 22: 2501-506, 1992.

GEA, S.; GRUPPI, A.; BASSO, B.; MENSO, E.; VOTTERO-CIMA, E. Antibodies to Trypanosoma cruzi cytosol acidic antigens (FIV) in Chagas' disease recognize parasite cell surface and human heart epitopes. J. Clin. Lab. Immunol., 31: 183-7, 1990.

GEA, S.; ORDONEZ, P.; CERBAN, F.; IOSA, D.;CHIZZOLINI, C.; VOTTEROCIMA, E. Chagas' disease cardioneuropathy: association of antiTrypanosoma cruzi and anti-sciatic nerve antibodies. Am. J. Trop. Med. Hyg., 49: 581-8, 1993.

GOLDEN, J.M. \& TARLETON, R.L. Trypanosoma cruzi: cytokine effects on macrophage trypanocidal activity. Exp. Parasitol. 72: 391-402, 1991.

GRABSTEIN, K.H.; URDAL, L.; TUSHISKI, R.J.; PRICE, V.L.; MOCHIZUKI, D.Y.; CANTRELL, M.A.; GILLIS, S.; CONLON, P.J. Induction of macrophages activity by granulocyte-macrophage colony-stimulating factor . Science, 232: 506-8, 1986.

GREEN,S.J.; CRAWFORD, R.M.; HOCKMEYER, J.T., MELTZER, M.S.; NACY, C.A. Leishmania major amastigotes initiate the L-arginine-dependent killing mechanism in IFN- $\gamma$ stimulated macrophages by induction of tumor necrosis factor- $\alpha$. J. Immunol. 145: 4290-297, 1990.

GRIFFIN, J.P. \& ORME, I.M. Evolution of CD4 T-cell subsets following infection of naive and memory immune with Mycobacterium tuberculosis. Infect. Immun., 62:1683-90, 1994.

HABERKORN, A. \& GONNERT, R. Animal experimental investigations in the activity of Nifurtimox against T.cruzi. Arzneim Forsh., 22: 1570-81, 1972.

HAMILTON, J.A. Colony stimulating factors, cytockines and monocytemacrophages--some controversies. Immunol. Today, 14: 18-24, 1993.

HAREL-BELLAN, A.M.; JOSKOWICZ, M.; FRADELIZI, D.; EISEN, H. Modification of $\mathrm{T}$ cell proliferation and interleukin-2 production in mice 
infected with Trypanosoma cruzi. Proc. Natl. Acad. Sci. USA, 80: 3466469, 1983.

HAREL-BELLAN, A; JOSKOWICZ, M.; FRADELIZI, D.; EISEN, H. T lymphocyte function during experimental Chagas disease: production of and response to interleukin 2. Eur. J. Immunol., 15: 438-42, 1985.

HATCHER, F.M. \& KUHN, R.E. Destruction of Trypanosoma cruzi by Natural Killer Cells. Science, 218: 295-96, 1982.

HIGUCHI, M.; DE BRITO, T.; REIS, M.M.; BARBOSA, A.; BELLOTTI, G.; PEREIRA-BARRETO, A.C.; PILEGGI, F. Correlation between Trypanosoma cruzi parasitism and myocardial inflammatory infiltrate in human chronic chagasic myocarditis: light microscopy and immunohistochemical findings. Cardiovasc. Pathol., 2: 101-6, 1993.

HOFT, D.F.; LYNCH, R.G.; KIRCHHOFF, L.V. Kinetic analysis of antigenspecific immune responses in resistant and susceptible mice during infection with Trypanosoma cruzi. J. Immunol., 151: 7038-47, 1993.

HSU, D.H.; DE WAAL MALEFYT, R.; FIORENTINO, D.F.; DANG, M.N.; VIEIRA, P.; DE VRIES, J.E.; SPITS, H.; MOSMANN, T.R.; MOORE, K.W. Expression of interleukin-10 activity by Epstein-Barr virus protein BCRF1. Science, 250: 830-2, 1990.

HUNTER C.A.; ELLIS-NEYES L.A.; SLIFER T., KANALY S., GRUNIG G., FORT M., RENNICK D., ARAUJO F. G. IL-10 is required to prevent immune hyperactivity during infection with Trypanosoma cruzi. $\mathbf{J}$. Immunol., 158: 3311-316, 1997.

JAMES, S.L.; KIPINS, T.L.; SHER, A.; HOFF, R. Enhanced resistance to acute infection with Trypanosoma cruzi in mice treated with an interferon induce. Infect. Immunity, 35: 588-93, 1982.

JONES, E.M.; COLLEY, D.G.; TOSTES, S.; LOPES, R.; VNENCAK-JONES, C.L.; MCCURLEY, T. Amplification of a Trypanosoma cruzi DNA 
sequence from inflammatory lesions in human chagasic cardiomyopathy. Am. J. Trop. Med. Hyg., 48: 348-57, 1993.

KEHRL, J.H., TAYLOR, A., KIM, S.J.; FAUCI, A.S. Transforming growth factorbeta is a potent negative regulator of human lymphocytes. Ann. N. York Acad. Sci., 628: 345-53, 1991.

KIERSZENBAUM, F. \& HAYES, M. M. Mechanisms of resistance against experimental T.cruzi infection. Requirements for cellular destruction of circulating forms of T.cruzi in human and murine in vitro systems. Immunology, 40: 61-6, 1980a.

KIERSZENBAUM, F. \& HOWARD, J. G. Mechanisms of resistance against experimental Trypanosoma cruzi infection: The importance of antibodies and antibody-forming capacity in the Biozzi high and low responder mice. J. Immunol., 116: 1208-11, 1976.

KIERSZENBAUM, F. \& LIMA, M. F. Susceptibility of insect borne, metacyclic forms of Trypanosoma cruzi to antibody - mediated mechanism of destruction. Am. J. Trop. Med. Hyg., 32: 1236-41, 1983.

KIERSZENBAUM, F.; KNECHT, E.; BUDZKO, D.B.; PZZIMENTI, M.C. Phagocytosis: a defence mechanism against infection with Trypanosoma cruzi. J. Immunol., 112: 1839-44, 1974.

KIPNIS, T. L.; DAVID, J. R.; ALPER, C. A.; SHER, A.; DIAS DA SILVA, W. Enzimatic treatment transform trypomastigotes of Trypanosoma cruzi into activators of alternative complement pathway and potentiates their uptake by macrophages. Proc. Nat. Acad. Sci. USA, 78: 602-5, 1981.

KIPNIS, T.L.; KRETTLI, A.U.; DIAS DA SILVA, W. Transformation of trypomastigote forms of Trypanosoma cruzi into activators of alternative complement pathway by immune IgG fragments. Scand. J. Immunol., 22: 217-26, 1985. 
KLAUS, G.G.B.; PEPYS, M.B.; KITAJIMA, K.; ASKONAS, B.A. Activation of mouse complement by different classes of mouse antibody. Immunology, 38: 687-95, 1979.

KOBAYASHI, M.; FITZ, L.; RYAN, M.; HEWICK, R.M.; CLARK, S.C; CHAN, S.H.; LOUDON, R.; SHERMAN, F.; PERUSSIA, B.; TRINCHIERI, G. Identification and purification of natural killer cell stimulatory factor (NKSF), a cytokine with multiple biologic effects on human lymphocytes. J. Exp. Med., 170: 827-45, 1989.

KOBERLE, F. Pathogenis of Chagas' disease. In: Trypanosomiasis and Leishmaniasis with special reference to Chagas' disease. Ciba Found Symp., 20: 136, 1974.

KOS, F.J. \& ENGLEMAN, E.G. Immune regulation: a critical link between NK cells and CTLs. Immunol. Today, 17: 174-76, 1996.

KRETTLI, A.U. Efeito de anticorpos e do complemento sobre tripomastigotas sanguíneos de camundongos infectados com Trypanosoma cruzi. Belo Horizonte, 1978 (Tese de Doutorado - Instituto de Ciências Biomédicas da Universidade Federal de Minas Gerais).

KRETTLI, A.U.; WEISZ-CARRINGTON, R.; NUSSENZWEIG, R. Membrane bound antibodies to bloodstream Trypanosoma cruzi in mice: strain differences in susceptibility to complement mediated lyses. Clin. Exp. Immunol., 37: 416-23, 1979.

KROEMER, G. \& WICK, G. The role of interleukin 2 in autoimmunity. Immunol. Today, 10: 246-51, 1989.

KUBIN, M.; CHOW, J.M.; TRINCHIERI, G. Differential regulation of interleukin12 (IL-12), tumor necrosis factor- $\alpha$, and IL-1 $\gamma$ production in human myieloid leukemia cell lines and peripheral blood mononuclear cells. Blood, 83: 1847-55, 1993. 
KÜHN R.; LÖHLER J.; RENNICK D., LOHLER J., RENNICK D., RAJEWSKY K., MULLER W. Interleukin-10 deficient mice develop chronic enterocolitis. Cell, 75: 203-74, 1993.

LAGUENS, R.P.; CABEZA MECKERT, P.; CHAMBO, G. Origin and significance of anti-heart and anti-skeletal muscle antibodies in Chagas' disease. Res. Immunol., 142: 160-3, 1991.

LANGERMANS, J.A.M.; VAN DER HULST, M.E.B.; NIBBERING, P.H.; HIEMSTRA, P.S.; FRANSEN, L.; VAN FURTH, R. IFN- $\gamma$, induced Larginine dependent toxoplasmastatic activity in murine peritonial macrophages is mediated by endogenous tumor necrosis factor- $\alpha$. $\mathbf{J}$. Immunol. 148: 568-74, 1992.

LEE, W.T.; YIN, X.M.; VITETTA, E.S. Functional and ontogenic analysis of murine CD45 hi and CD45lo CD4 ${ }^{+}$T cells. J. Immunol.,144: 3288-295, 1990.

LLOP, E.; ROTHHAMMER F.; ACUNA M.; APT, W. HLA antigens in cardiomyopathic Chilean chagasics. Am. J. Hum Gen, 43: 770-73, 1988.

LOPES, E.R. \& CHAPADEIRO, E. Anatomia patológica da doença de Chagas. In: . Dias, J.C.P. \& Coura, J.R. (eds). Clínica e terapêutica da doença de Chagas. Rio de Janeiro: FIOCRUZ, 1997. p.67-8.

MANETTI, R.; GEROSA, F.; GIUDIZI, M.G.; BAGIOTTI, R.; PARRONCHI, P.; PICCINNI, M-P.; SAMPOGNARO, S.; MAGGI, E.; ROMAGNANI, S.; TRINCHIERI, G. Interleukin -12 induces stable priming for interferon $\gamma$ (IFNg- $\gamma$ ) production during differentiation of human $\mathrm{T}$ helper (Th) cells and transient IFN- $\gamma$ production interleukin established Th2 cell clones. J. Exp. Med., 179: 1273-83, 1994.

MANETTI, R.; PARRONCHI, P.; GIUDIZI, M.G.; PICCINNI, M-P.; MAGGI, E.; TRINCHIERI, G.; ROMAGNANI, S. Natural killer cell stimulatory factor (Interleukin 12 [IL-12]) induces T helper type 1 (Th1)-specific immune 
responses and inhibits the development of IL-4-producing Th cells. J. Exp. Med., 177: 1199-204, 1993.

MARTIN, R.M. \& LEW, A.M. Is IgG2a a good Th1 marker in mice? Immunol. Today, 19: 49, 1998.

METCALF, D. The excess numbers of peritoneal macrophages in granulocytemacrophage colony-stimulating factor transgenic mice are generated by local proliferation. J. Exp. Med., 175: 877-84, 1992.

MILEI, J.; SANCHEZ, J.; STORINO, R.; YU, Z. X.; DENDUCHIS, B.; FERRANS, V.J. Antibodies to laminin and immunohistochemical localisation of laminin in chronic chagasic cardiomyopathy: a review. Mol. Cell. Biochem., 129: 161-70, 1993.

MINOPRIO, P.; ANDRADE, L.; LEMBEZAT, M.P.; OZAKI, L.S.; COUTINHO, A. Indiscriminate representation of $\mathrm{VH}$-gene families in the murine $\mathrm{B}$ lymphocyte responses to Trypanosoma cruzi. J. Immunol., 142: 4017-21, 1989a.

MINOPRIO P.; BANDEIRA A.; PEREIRA P., MOTA SANTOS T., COUTINHO A. Preferential expansion of Ly1-B and CD4 CD8 ${ }^{-} \mathrm{T}$ cells in the polyclonal lymphocyte responses to murine Trypanosoma cruzi infection. Int. Immunol., 1: 176-184, 1989b.

MINOPRIO, P.; EL CHEIKH, M.C.; MURPHY, E; HONTEBEYRIE-JOSKOWICZ, M.; COFFMAN, R.; COUTINHO, A; O'GARRA, A. Xid-associated resistance to experimental Chagas' disease is IFN-gamma dependent. $\mathbf{J}$. Immunol., 151: 4200-8, 1993.

MINOPRIO, P.M.; EISEN, H.; FORNI, L.; D'IMPÉRIO LIMA, M.R.; JOSKOWICZ, M; COUTINHO, A. Polyclonal lymphocyte responses to murine Trypanosoma cruzi infection. I. quantitation of both T- and B-cell responses. Scand. J. Immunol., 24: 661-8, 1986.

MINOPRIO, P; BURLEN, O; PEREIRA, P.; GUILBERT, B.; ANDRADE, L.; HONTEBEYRIE-JOSKOWICZ, M.; COUTINHO, A. Most B cells in acute 
Trypanosoma cruzi infection lack parasite specificity. Scand. J. Immunol., 28: 553-61, 1988.

MOSMANN T.R. \& MOORE K.W.M. The role of IL-10 in cross-regulation of Th1 and Th2 responses. Immunol. Today, 12: 49-53, 1991.

MOSMANN T.R.; SCHUMAKER J.H.; STREET N.F., BUDD R., O'GARRA A., FONG T. A., BOND M. W., MOORE K. W., SHER A., FIORENTINO D. F. Diversity of cytokine synthesis and function of mouse $\mathrm{CD}^{+}{ }^{+} \mathrm{T}$ cells. Immunol. Rev., 123: 209-29, 1991.

MOSMANN, T.R. \& SAD, S. The expanding universe of T-cell subsets: Th1, Th2 and more. Immunol. Today, 17: 138-46, 1996.

MOSMANN, T.R.; CHERWINSKI, H.; BOND, M.W.; GIEDLIN, M.A.; COFFMAN, R.L. Two types of murine helper $T$ cell clone. I. Definition according to profiles of lymphokine activities and secreted proteins. J. Immunol., 136: 2348-57,1986.

MUNIZ, J. \& BORRIELO, A. Estudo sobre a ação lítica de diferentes soros sobre as formas de cultura e sanguíneos de Schizotrypanum cruzi. Rev. Bras. Biol., 5: 563, 1945.

MUÑOZ-FERNANDEZ M.A.; FERNANDEZ M.A.; FRESNO M. Synergism between tumor necrosis factor-alpha and interferon-gamma on macrophage activation for the killing of intracellular Trypanosoma cruzi through a nitric oxide-dependent mechanism. Eur. J. Immunol, 22: 301307, 1992.

NABORS, G.S. \& TARLETON, R.L. Differential control de IFN $\gamma$ and IL-2 production during T. cruzi infection. J. immunol.,146: 3591-598, 1991.

NOGUEIRA, N.; CHAPLAN, S.; REESINK, M.; TYDINGS, J.; COHN, Z. Trypanosoma cruzi: induction of microbicidal activity in human mononuclear phagocytes. J. Immunol., 128: 2142-6, 1982. 
O'GARRA, A.,CHANG, R.; GO, N.; HASTINGS, R.; HAUGHTON, G.; HOWARD, M. Ly-1 B (B-1) cells are the main source of $B$ cell-derived interleukin 10. Eur. J. Imunnol., 22: 711-17, 1992.

OKUMURA, M. \& THOMAS, M.L. Regulation of immune function by protein tyrosine phosphatases. Curr. Opin. Immunol., 7: 312-19, 1995.

OLIVARES FONTT, E.; HEIRMAN, C.; THIELEMANS, K.; VRAY, B. Granulocyte-macrophage colony-stimulating factor: involvement in control of Trypanosoma cruzi infection in mice. Infect. Immun., 64: 3429-3434, 1996.

ORTIZ-ORTIZ, L.; PARKS, D.E.; RODRIGUEZ, M.; WEIGLE, W.O. Polyclonal B lymphocyte activation during Trypanosoma cruzi infection. J. Immunol., 124: 121-6, 1980.

PAUL, W.E. \& SEDER, R.A. Lymphocyte responses and cytokines. Cell., 76: 241-51, 1994.

PLATA, F.; GARCIA-PONS, F.; WIETZERBIN, J. Immune resistance to Trypanosoma cruzi: synergy of specific antibodies and recombinant interferon gamma in vivo. Ann. Inst. Pasteur Immunol., 138: 397-415, 1987.

PLATA, F.; WIETZERBIN, J.; GARCIA-PONS, F.; FALCOFF, E.\& EISEN, H. Synergistic protection by specific antibodies and interferon against infection by Trypanosoma cruzi in vitro. Eur. J. Immunol., 14: 930-35, 1984.

POSTAM, M.; BAILEY, J.J.; DVORAK, J.A. , MC DANIEL J. P. , POTTALA E. W. Studies of Trypanosoma cruzi clones in inbred mice. III Histopathological and electrocardiographical responses to chronic infection. Am. J. Trop. Med. Hyg., 37: 541-49, 1987.

POWRIE, F. \& MASON, D. Ox-22 $2^{\text {High }} \mathrm{CD} 4^{+}$T cells induce wasting disease with multiple organ pathology: Prevention by the Ox-22 ${ }^{\text {Low }}$ subset. J. Exp. Med., 172: 1701-708, 1990. 
POWRIE, F.; CORREA-OLIVEIRA, R.; MAUZE, S.,COFFMAN R. L. Regulatory interactions between $C D 45 R B^{\text {High }}$ and CD45RB ${ }^{\text {Low }}$ cells are important for the balance between protective and pathologic cell-mediated immunity. J. Exp. Med., 179: 589-600, 1994.

REED, S.G. In vivo administration of recombinant IFN-gamma induces macrophage activation, and prevents acute disease, immune suppression, and death in experimental Trypanosoma cruzi infections. J. Immunol., 140: 4342-7, 1988.

REED, S.G.; BROWNELL, C.E.; RUSSO, D.M.; SILVA, J.S.; GRABSTEIN, K.H.; MORRISSEY, P.J. IL10 mediates susceptibility to Trypanosoma cruzi infection. J. Immunol., 153: 3135-40, 1994.

REED, S.G.; NATHAN, C.F.; PIHL, D.L.; RODRICK, S.P.; SHANEBECK, K.; CONLON, P.J; GRABSTEIN, K.H. Recombinant granulocyte/macrophage colony-stimulating factor activates macrophages to inhibit Trypanosoma cruzi and release hydrogen peroxide. J. Exp. Med., 166: 1734-46, 1987.

REED, S.G.; ROTERS, S.B.; GOIDL, E.A. Spleen cell-mediated suppression of IgG production to a non-parasite antigen during chronic Trypanosoma cruzi infection in mice. J. Immunol., 131: 1978-82, 1983.

REY, L. Parasitologia - 2a edição. Rio de Janeiro. Guanabara Koogan ,1991. p. $104-12,138-52$.

RODRIGUEZ, A.M.; SANTORO, F.; AFCHAIN, D.; BAZIN, H.; CAPRON, A. Trypanosoma cruzi infection in B cell deficient rats. Infect. immun., 31: 524-9, 1981.

ROTTENBERG, M.E.; BAKHIET, M; OLSSON, T; KRISTENSSON, K.; MAK, T; WIGZELL, H.; ÖRN, A. Differential susceptibilities of mice genomically deleted of CD4 and CD8 to infections with Trypanosoma cruzi or Trypanosoma brucei. Infect. Immun., 61: 5129-33, 1993.

ROTTENBERG, M.E.; RIARTE, A.; SPORRONG, L.; ALTRCHECH, J.; PETRAY, P.; RUIZ, A.M.; WIGZELLI, H.; ÖRN, A. Outcome of infection 
with different strains of Trypanosoma cruzi in mice lacking $\mathrm{CD} 4^{+}$and/or CD8 ${ }^{+}$. Immunol. Lett., 45: 53-60, 1995.

ROWLAND, E.C. \& KUHN, R.E. Suppression of cellular responses in mice during Trypanosoma cruzi infections. Infect. Immun., 20: 393-7, 1978.

RUPPERT, E. E. \& BARNES, R. D. Invertebrate Zoology - 6th ed. New York: Saunders College Publishing, 1994. p. 10-67.

RUSCETTI, F.;VARESIO, L.; OCHOA, A.; ORTALDO, J. Pleiotropic effects of transforming growth factor-beta on cells of the immune system. Ann. N. York Acad. Sci., 685: 488-500, 1993.

RUSSO, M.; STAROBINAS, N.; MARCONDES, M.C.G.; MINOPRIO, P.; HONTEBEYRIE-JOSKOWICZ, M. The influence of $T$ cell subsets on Trypanosoma cruzi multiplication in different organs. Immunol. Lett., 49: 163-8, 1996.

RUSSO, M.; STAROBINAS, N.; MINOPRIO, P.; COUTINHO, A.; HONTEBEYRIE-JOSKOWICZ, M. Parasitic load increases and myocardial inflammation decreases in Trypanosoma cruzi infected mice after inactivation of helper T cells. Ann. Inst. Pasteur/Immunol., 139: 225-36, 1988.

SADIGURSKY, M.; ACOSTA, A.M.; SANTOS-BUCH, C.A. Muscle sarcoplasmic reticulum antigen shared by Trypanosoma cruzi clone. Am. J. Trop. Med. Hyg., 31: 934-41, 1982.

SALGAME, P.; ABRAMS, J.S.; CLAYBERGER, C.; GOLDSTEIN, H.; CONVIT, J.; MODLIN, R.L.; BLOOM, B.R. Differing lymphokine profiles of functional subsets of human CD4 and CD8 T cell clones. Science, 254: 279-82, 1991.

SALLUSTO, F.; MACKAY, C.R.; LANZAVECCHIA, A. Selective expression of the eotaxin receptor CCR3 by human T helper 2 cells. Science, 277: 2005-7, 1997. 
SCOTT, M.T. \& GROSS-SAMPSON, M. Restricted IgG isotype profiles in Trypanosoma cruzi infected mice and Chagas' disease patients. Clin. Exp. Immunol., 58: 372-9, 1984.

SEDGWICK, J.D. \& HOLT, P.G. A solid-phase immunoenzimatic technique for enumeration of specific antibody-secreting cells. J Immunol. Methods, 57: 301-9, 1983.

SEGURA, M.A.; MOLINE DE RASPI, A.; BASOMBRIO, M.A. Reversibility of muscle and heart lesions in chronic $T$. cruzi infected mice after late trypanocidal treatment. Mem. Inst. Oswaldo Cruz, 89: 213-16, 1994.

SILVA, J.S.; MORRISSEY, P.J.; GRABSTEIN, K.H.; MOLLER, K.M.; ANDERSON, D.; REED, S.G. Interleukin 10 and interferon- $\gamma$ regulation of experimental Trypanosoma cruzi infection. J. Exp. Med., 175: 169-74, 1992.

SILVA, J.S.; TWARDZIK, D.R.; REED, S.G. Regulation of Trypanosoma cruzi infections in vitro and in vivo by transforming growth factor beta (TGFbeta). J. Exp. Med., 174: 539-45, 1991.

SILVA, L.H.P. \& NUSSENZWEIG, V. Sobre uma cepa de Trypanosoma cruzi altamente virulenta para o camundongo branco. Folia Clin. Biol., 20: 191203, 1953.

SKEIKY, Y.A.; BENSON, D.R.; GUDERIAN, J.A.; SLEATH, P.R.; PARSONS, M.; REED, S.G. Trypanosoma cruzi acidic ribosomal $P$ protein gene family. Novel $P$ proteins gene family. Novel $P$ proteins encoding unusual cross-reactive epitopes. J. immunol., 151: 5504-15, 1993.

SNAPPER, C.M. \& PAUL, W.E. B cell stimulatory factor-1 (interleukin 4) prepares resting murine $B$ cells to secrete $\lg G 1$ upon subsequent stimulation with bacterial lipopolysaccharide. J. Immunol., 139: 10-7, 1987.

SNAPPER, C.M.; MCINTYRE, T.M.; MANDLER, R.; PECANHA, L.M.; FINKELMAN, F.D.; LEES, A.; MOND, J.J. Induction of IgG3 secretion by 
interferon gamma: a model for T-cell independent class switching in response to T-cell independent type 2 antigens. J. Exp. Med., 175: 136771, 1992.

SOONG, L. \& TARLETON, R.L. Trypanosoma cruzi infection suppresses nuclear factors that bind to specific sites on the interleukin 2 enhancer. Eur. J. Immunol., 24: 16-23, 1994.

SPINELLA, S.; LIEGEARD, P.; HONTEBEYRIE-JOSKOWICZ, M. Trypanosoma cruzi: Predominance of IgG2a in non-specific humoral response during experimental Chagas' disease. Exp. Parasitol., 74: 46-56, 1992.

STEFANI, M.N.A.; TAKEHARA, H.A.; MOTA, I. Isotype of antibodies responsible for immune lysis in Trypanosoma cruzi infected mice. Immunol. Lett., 7: 91-7, 1983.

STERIN-BORDA, L.; PEREZ-LEIROS, C.; WALD, M.; CREMASCHI, G.; BORDA, E. Antibodies to beta 1 and beta 2 adrenoreceptors in Chagas' disease. Clin. Exp. Immunol., 74: 349-54, 1988.

TAFURI, W.L. Patogenia da doença de Chagas. Rev. Inst. Med. Trop. São Paulo, 29: 194-99, 1987.

TAGA, K. \& TOSATO, G. IL-10 inhibits human T cell proliferation and IL-2 production. J. Immunol., 148: 1143-48, 1992.

TAKEHARA, H.A; PERINI, A.; SILVA, M.H.; MOTA, I. Role of different antibody classes in protection against infection in mouse. Exp. Parasitol., 52: 13746, 1981.

TAMBOURGI, D.V.; KIPNIS, T.L.; DIAS DA SILVA, W. T.cruzi: antibodydependent killing of bloodstream trypomastigotes by mouse bone marrow derived mast cells and by mastocytoma cells. Exp. Parasitol., 68: 192201, 1989.

TARLETON, R.L \& ZHANG, L. Characterization of citokine production in murine Trypanosoma cruzi infection by in situ immunocytochemistry: lack of 
association between susceptibility and type 2 cytokine production. Eur. $\mathbf{J}$. Immunol., 26: 102-9, 1996.

TARLETON, R.L. Depletion of $\mathrm{CD}^{+} \mathrm{T}$ cells increases susceptibility and reverses vaccine-induced immunity in mice infected with Trypanosoma cruzi. J. Immunol., 144: 717-24, 1990.

TARLETON, R.L. Pathology of American trypanosomiasis. In: Warren, K.S. (Ed). Immunology and molecular biology of parasitic infections $3 \mathrm{ed}$. Boston: Blackwell, 1993. p 64-71.

TARLETON, R.L. Regulation of immunity in Trypanosoma cruzi infection. Exp. Parasitol., 73: 106-9, 1991.

TARLETON, R.L. Trypanosoma cruzi induced suppression of IL-2 production. II. Evidence for a role for suppressor cells. J. Immunol., 140: 2769-73, 1988.

TARLETON, R.L.; KOLLER, B.H.; LATOUR, A.,POSTAN M. Susceptibility of $\beta 2$ microglobulin-defficient mice to Trypanosoma cruzi infection. Nature, 356: 338-40, 1992.

TARLETON, R.L.; ZHANG, L.; DOWNS, M.O. "Autoimmune rejection" of neonatal heart transplants in experimental Chagas disease is a parasitespecific response to infected host tissue. Proc. Natl. Acad. Sci. USA 94: 3932-37, 1997.

TEIXEIRA, A.R. T.cruzi e Doenças de Chagas IC - Modos de transmissão; ID Incidência e importância econômica. In: Doenças de Chagas e outras doenças por tripanossomas, Brasília: Ed. Univ. de Brasília, 1987. p. 1922.

TEIXEIRA, A.R.; TEIXEIRA, G.; MACEDO, V.; PRATA, A. Acquired cellmediated immunodepression in acute Chagas' disease. J. Clin. Invest., 62: 1132-41, 1978.

TERNYNCK, T.; BLEUX, C.; GREGOIRE, J.; AVRAMEAS, S.; KANELLOPOULOS-LANGEVIN, C. Comparison between autoantibodies 
arising during Trypanosoma cruzi infection in mice and natural autoantibodies. J. Immunol., 144: 1504-11, 1990.

TIBBETTS, R.S.; McCORMICK, T.S.; ROWLAND, E.C.; MILLER, S.D.; ENGMAN, D.M. Cardiac antigen-specific autoantibody production is associated with cardiomyopathy in Trypanosoma cruzi-infected mice. J. Immunol., 152: 1493-9, 1994.

TOWBIN, H.; ROSENFELDER, G.; WIESLANDER, J.; AVILA, J.L.; ROJAS, M.; SZARFMAN, A.; ESSER, K.; NOWACK, H.; TIMPL, R. Circulating antibodies to mouse laminin in Chagas disease, American cutaneous leishmaniasis, and normal individuals recognize terminal galactosyl (alpha 1-3) - galactose epitopes. J. Exp. Med., 166: 419-32, 1987.

TRINCHIERI, G. \& SCOTT, P. Immunoregulation by interleukin-12. Res. Immunol., 146: 423-31, 1995.

UMEKITA, L.F. \& MOTA, I. In vitro lysis of sensitised Trypanosoma cruzi by platelets: role of C3b receptors. Parasite Immunol., 11: 561-6, 1989.

UMEKITA, L.F. Possíveis Mecanismos envolvidos no "clearance" imune de tripomastigotas sanguícolas de Trypanosoma cruzi. São Paulo, 1991 (Tese de Dotorado - Instituto de Ciências Biomédicas da Univ. de São Paulo).

VAGO, A.R.; MACEDO, A.M.; ADAD, S.J.; D'AVILA REIS, D. ; CORREIA DE OLIVEIRA, R. PCR detection Trypanosoma cruzi DNA in oesophageal tissues of patients with chronic digestive Chagas' disease. Lancet, 348: 891-92, 1996.

VAN VOORHIS, W.C. \& EISEN, H. FL160. A surface antigen of Trypanosoma cruzi that mimics mammalian nervous tissue. J. Exp. Med., 169: 641-52, 1989.

VESPA, G.N.; CUNHA, F.Q.; SILVA, J.S. Nitric oxide is involved in control of Trypanosoma cruzi - induced parasitemia and directly kills the parasite in vitro. Infect. Immun., 62: 5177-82, 1994. 
VIA, C.S. \& SHEARER, G.M. T- cell interactions in autoimmunity: insights from a murine models of graft-versus-host disease. Immunol. Today, 9: 20713, 1988.

VIOTTI, R.; VIGLIANO, C.; ARMENTI, H., SEGURA E. Treatment of chronic Chagas' disease with benzonidazole: Clinical and serological evolution of patients with long-term follow-up. Am. Heart J., 127: 151-62, 1994.

WHO. Control of Chagas' disease. Report of a WHO Expert Committe. WHO Technical Report Series. No. 811, Geneva, 1991. p.95.

WILSON, K.C. \& FINBLOOM, D.S. Interferon gamma rapidly induces in human monocytes a DNA-binding factor that recognizes the gamma response region within the promoter of the gene for the high-affinity Fc gamma receptor. Proc. Natl. Acad. Sci. USA., 89: 11964-68, 1992.

WIRTH, J. J.; KIERSZENBAUM, F.; SONNENFELD, G.; ZLOTNIZ, A. Enhancing effects of gamma interferon on phagocytic cell association with and killing of T. cruzi. Infect. Immun., 49: 61-6, 1985.

WOOD, J.N.; HUDSON, L.; JESSEL, T.M.; YAMAMOTO, M. A monoclonal antibody defining antigenic determinants on subpopulations of mammalian neurones and Trypanosoma cruzi parasites. Nature, 296: 34-8, 1982.

WU, C.Y.; DEMEURE, C.; KINIWA, M.; GATELY, M.; DELESPESSE, G. IL-12 induces the production of IFN- $\gamma$ by neonatal human $\mathrm{CD}^{+} \mathrm{T}$ cells. $\mathbf{J}$. Immunol., 151: 1938-49, 1993.

YAKURA, $\mathrm{H}$. The role of protein tyrosine phosphatases in lymphocyte activation and differentiation. Cr. Ver. Immunol., 14: 311-36, 1994.

ZHANG, L. \& TARLETON, R.L. Characterization of cytokine production in murine Trypanosoma cruzi infection by in situ immunocytochemistry: lack of association between susceptibility and type 2 cytokine production. Eur. J. Immunol., 26: 102-9, 1996b.

ZHANG, L. ,TARLETON, R.L. Persistent production of inflammatory and antiinflammatory cytokines and associated $\mathrm{MHC}$ and adhesion molecule 
expression at the site of infection and disease in experimental

Trypanosoma cruzi infections. Exp. Parassitol., 84(2): 203-13, 1996 a.

ZURAWSKI, G. \& DE VRIES, J.E. Interleukin 13, an interleukin 4-like cytokine
that acts on monocytes and B cells, but not on T cells. Immunol. Today, 15: 19-26, 1994.

\section{Anexo I: Artigo publicado em periódico}

Marinho, C. R. F.; D'Império Lima, M. R.; Grisotto, M.G \& Alvarez, J. M. "Influence of acute phase parasite load on pathology, parasitism and activation of the immune system at the late chronic phase of Chagas'disease". Infection \& Immunity, 67(1): 308-318, 1999.

Abstract: To obtain low and high parasite loads in the acute phase of Chagas' disease, $A / J$ mice were infected with 10(3) or 10(5) Trypanosoma cruzi trypomastigotes of the Y strain and treated on day 6 with benznidazol, One year later, chronically infected mice were screened for subpatent parasitemias, tissue pathology, and immune response. Mice infected with the high parasite inoculum showed higher levels of chronic parasitemias, heart and striated muscle inflammation, and activation of the immune system than did mice infected with the low inoculum, Concerning the activation of the immune system, the main findings for highdose-infected mice were (i) increased numbers of splenocytes, with preferential expansion of CD8(+) and B220(-) CD5(-) cells, many of them hearing a macrophage phenotype; (ii) higher frequencies of B (B220(+)), $\mathrm{CD} 4(+)$, and CD8(+) large lymphocytes; (iii) a shift of CD4(+) cells towards a CD45RB(Low) phenotype; (iv) increased frequencies of both CD45RB(Low) and CD45RB(high) large CD-4(+) cells; (v) augmented numbers of total immunoglobulin (Ig)-secreting cells, with predominance of IgG2a-producing cells; and (vi) increased production of gamma interferon and interleukin 4. In addition, these mice presented lower IgM and higher IgG2a and IgG1 parasite-specific serum antibody levels, Our results indicate that the parasite load at the acute phase of T. cruzi infection influences the activation of the immune system and development of Chagas' disease pathology at the late chronic phase of the disease. 